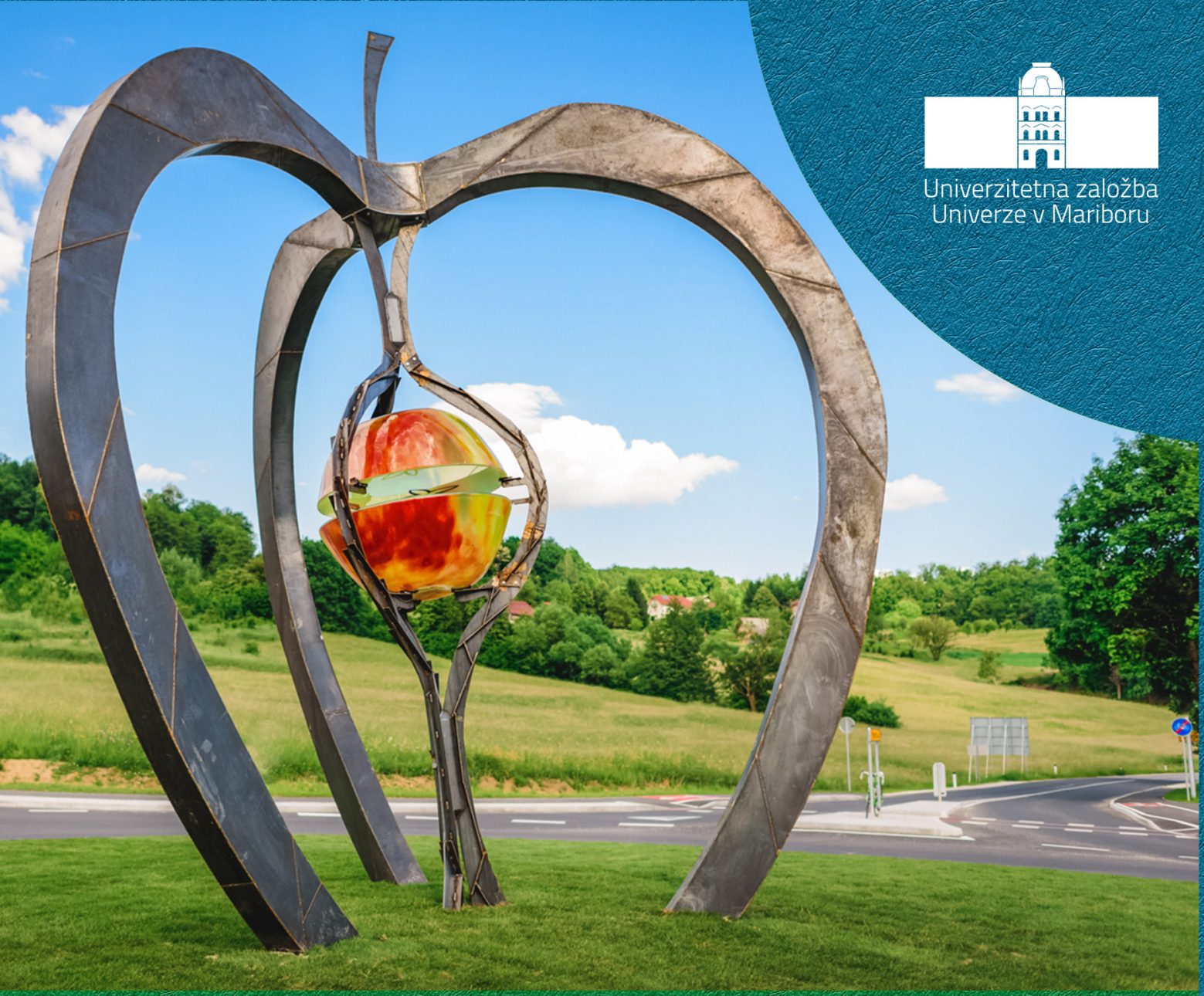

\title{
PRIPOROČILA ZA
}

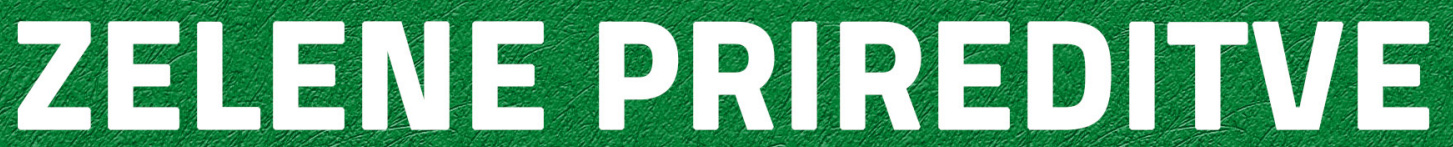
PRIMER PRIREDITVE PRAZNIK KOZJAMSKEGA IABOLKA

BARBARA PAVILIOVIÉ TAUA LESTIK STUHEC UREDMICI 


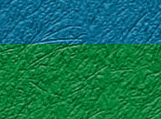




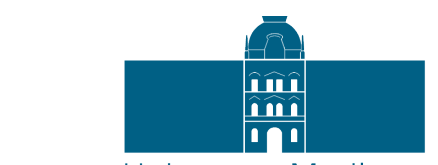

Univerza v Mariboru

Fakulteta za turizem

\section{Priporočila za zelene prireditve}

Primer prireditve Praznik kozjanskega jabolka

Urednici

Barbara Pavlakovič

Tanja Lešnik Štuhec

Oktober 2021 
Naslov Priporočila za zelene prireditve

Title Recommendations for Green Events

\section{Podnaslov Primer prireditve Praznik kozjanskega jabolka \\ Subtitle an Example of the Korjansko Apple Festival \\ Urednici Barbara Pavlakovič \\ Editors (Univerza v Mariboru, Fakulteta za turizem) \\ Tanja Lešnik Štuhec \\ (Univerza v Mariboru, Fakulteta za turizem) \\ Recenzija Marko Koščak \\ Review (Univerza v Mariboru, Fakulteta za turizem) \\ Mojca Polak}

(Višja strokovna šola za gostinstvo in turizem Maribor)

Lektoriranje

Language editing

Amidas d.o.o. in Irena Hvala s.p

Tehnični urednik Jan Perša

Technical editor (Univerza v Mariboru, Univerzitetna založba)

Oblikovanje ovitka Jan Perša

Cover designer (Univerza v Mariboru, Univerzitetna založba)

Grafike na ovitku

Cover graphic

Fotografija Mojce Valenčak, 2021.

Grafične priloge

Graphic material

Javni zavod Kozjanski park, avtorji in urednici

Založnik

Univerza v Mariboru, Univerzitetna založba

Published by

Slomškov trg 15, 2000 Maribor, Slovenija

https://press.um.si, zalozba@um.si

Izdajatelj

Univerza v Mariboru, Fakulteta za turizem

Issued by

Cesta prvih borcev 36, 8250 Brežice, Slovenija

http://ft.um.si,ft@um.si

Izdaja

Edition

Prva izdaja

Vrsta publikacije

Publication type

E-knjiga

Izdano

Published

Maribor, Slovenija, oktober 2021

Dostupno na

Available at

http://press.um.si/index.php/ump/catalog/book/601 
Besedilo/ Text (C) Pavlakovič, Lešnik Štuhec in avtorji, 2021

To delo je objavljeno pod licenco Creative Commons Priznanje avtorstva 4.0 Mednarodna.

/ This work is licensed under the Creative Commons Attribution 4.0 International License.

Uporabnikom je dovoljeno tako nekomercialno kot tudi komercialno reproduciranje, distribuiranje, dajanje $\mathrm{v}$ najem, javna priobčitev in predelava avtorskega dela, pod pogojem, da navedejo avtorja izvirnega dela.

Vsa gradiva tretjih oseb v tej knjigi so objavljena pod licenco Creative Commons, razen če to ni navedeno drugače. Če želite ponovno uporabiti gradivo tretjih oseb, ki ni zajeto v licenci Creative Commons, boste morali pridobiti dovoljenje neposredno od imetnika avtorskih pravic.

https://creativecommons.org/licenses/by/4.0/

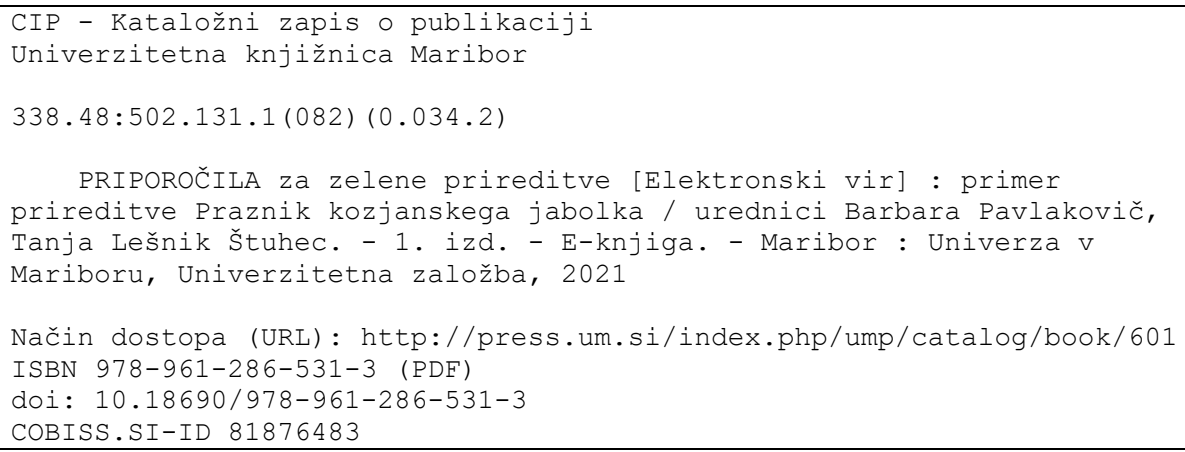

ISBN 978-961-286-531-3 (pdf)

DOI https://doi.org/10.18690/978-961-286-531-3

Cena
Price

Odgovorna osoba založnika Forpublisher

Citiranje Attribution prof. dr. Zdravko Kačič rektor Univerze v Mariboru
Pavlakovič, B. in Lešnik Štuhec, T. (ur.) (2021). Priporočila ₹a zelene prireditve: primer prireditve Praznik kozjanskega jabolka. Maribor: Univerzitetna založba. doi: 10.18690/978-961-286531-3 


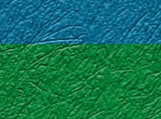




\section{Kazalo}

Uvod

Poglavje 1: Zelena pametna podeželska destinacija s certificiranimi gastronomskimi

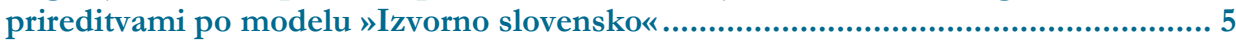

1.1 Zelena pametna podeželska destinacija ....................................................................... 6

1.2 Model znamčenja ponudbe s kolektivno blagovno znamko (KBZ) po modelu

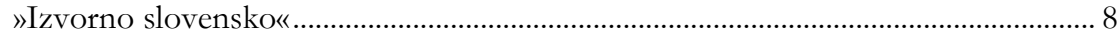

1.3 Zelene gastronomske prireditve, certificirane po modelu »Izvorno slovensko«.. 11

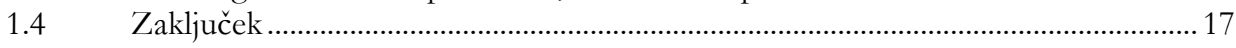

Poglavje 2: Prireditve v turizmu ................................................................. 19

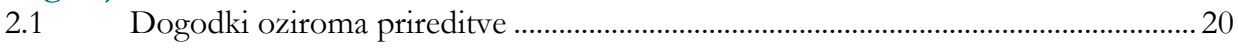

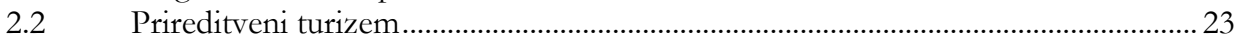

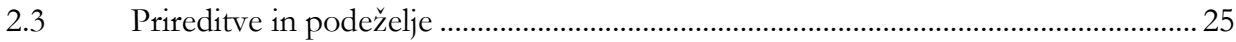

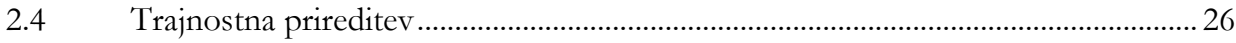

Poglavje 3: Predstavitev destinacije Podčetrtek, Bistrica ob Sotli in Kozje .............. 31

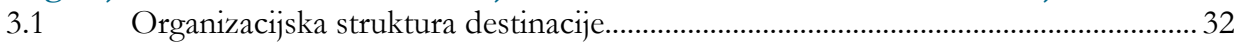

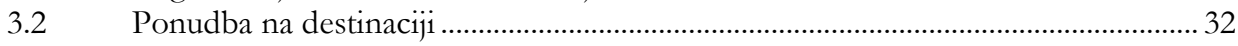

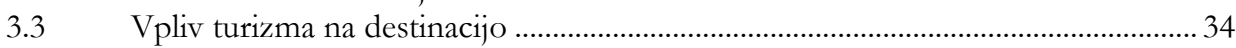

Poglavje 4: Javni zavod Kozjanski park in festival »Praznik kozjanskega jabolka«..37

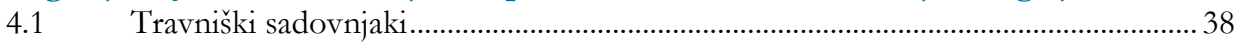

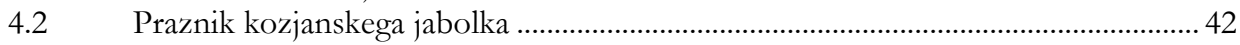

4.3 Kaj se dogaja v času Praznika kozjanskega jabolka?................................................ 44

Poglavje 5: Analiza destinacije in akcijski načrt ............................................... 51

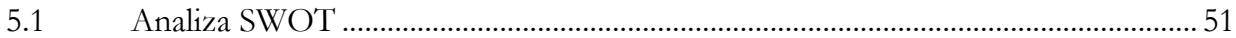

$5.2 \quad$ Vizija destinacije in kulturnega turizma ...................................................................... 53

5.3 Cilji in akcijski načrt kulturnega turizma.................................................................... 56

Poglavje 6: Smernice za trajnostne prireditve na destinaciji Podčetrtek, Bistrica ob

Sotli in Kozje ..........................................................................................75

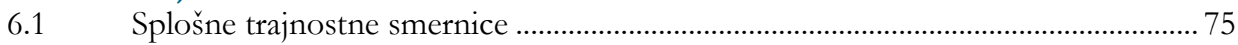

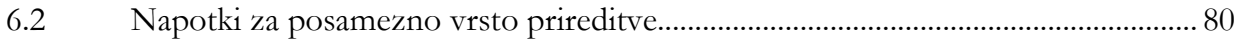

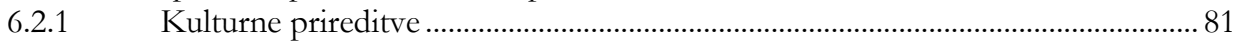

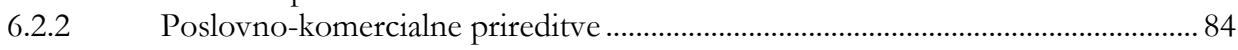

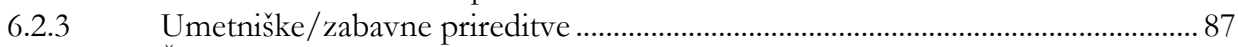

6.2.4 Športne/rekreacijske prireditve …....................................................................... 90 
6.2.5 Izobraževalne/znanstvene prireditve ................................................................... 92

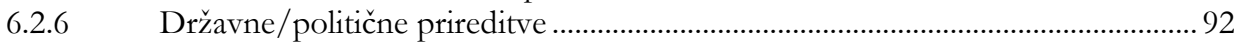

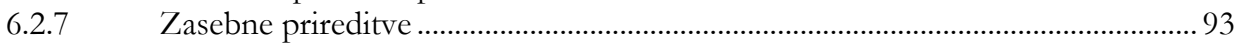

Poglavje 7: Priporočila za prireditev »Praznik kozjanskega jabolka« ......................95

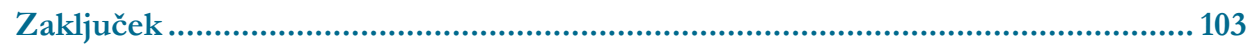

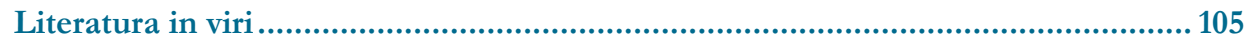

Recenziji monografije.............................................................................. 109 


\section{Uvod}

BARBARA PAVLAKOVIČ

Prireditve so eden temeljnih delov ponudbe kraja oziroma destinacije, ki želi svojim prebivalcem ponuditi nepozabno doživetje. Kot take so prireditve prav tako sestavni del turistične ponudbe in privlačen element za obiskovalce kraja. Pomena turizma se močno zavedajo na destinaciji Podčetrtek, Bistrica ob Sotli in Kozje, zato so v sodelovanju s Fakulteto za turizem Univerze v Mariboru pristopili k skupnemu projektu trajnostnih turističnih rešitev za prihodnost.

V projektu smo se sodelujoči osredotočili na trajnostne prireditve, saj je destinacija Podčetrtek, Bistrica ob Sotli in Kozje poznana po svojih odmevnih prireditvah, kot so Praznik kozjanskega jabolka, Festival vina in čokolade, Koza zmaj in še kaj ... Tako smo skupaj pripravili pričujočo monografijo z naslovom »Priporočila za zelene prireditve: primer prireditve Praznik kozjanskega jabolka«, saj smo se v sklopu projekta osredotočili prav na to prireditev. Hkrati pa smo ustvarili vsebino, ki se jo lahko uporabi in prilagodi za katero koli drugo prireditev, ki želi upoštevati smernice trajnostnega delovanja. 
V projekt so bili vključeni študenti 3. letnika univerzitetnega programa Turizem Fakultete za turizem Univerze $\mathrm{v}$ Mariboru ter študenta programa Erasmus $+\mathrm{z}$ mentoricama doc. dr. Tanjo Lešnik Štuhec ter asist. Barbaro Pavlakovič, ki sta v študijskem letu 2020/21 izvajali predmet Trajnostni razvoj. Kot predstavnika destinacije sta v projektu sodelovala Boštjan Misja, direktor Turizma Podčetrtek, Bistrica ob Sotli in Kozje GIZ, ter Mojca Kunst, direktorica Javnega zavoda Kozjanski Park.

Projekt je bil zastavljen v časovnem obdobju od oktobra do decembra 2020, ko bi si študenti osebno ogledali destinacijo in njene turistične ponudnike ter se udeležli festivala Praznik kozjanskega jabolka v oktobru 2020 v sklopu terenskih vaj. Tako bi imeli priložnost osebnega pogovora s ponudniki in obiskovalci. Žal je pandemija covida-19 preprečila te načrte, saj je bil zaradi ukrepov festival odpovedan, prehajanje regij in turistični obiski pa prepovedani. Posledično smo izvedbo projekta prilagodili in terenske vaje spremenili $\mathrm{v}$ spletno okroglo mizo s predstavniki destinacije, na kateri so študenti spoznali posamezne organizacije in ponudnike. Spletni dogodek v aplikaciji MS Teams je bil izveden 11. 11. 2020, na njem pa so sodelovali:

- Peter Misja, župan Občine Podčetrtek,

- Milenca Krajnc, županja Občine Kozje,

- Mojca Kunst, direktorica Javnega zavoda Kozjanski Park,

- Boštjan Misja, direktor Turizma Podčetrtek, Bistrica ob Sotli in Kozje GIZ,

- Vasja Čretnik, predstavnik podjetja Terme Olimia,

- Aleš Amon, direktor podjetja Amon d.o.o.

Pomemben del dogodka je bila tudi razprava, saj so študenti lahko postavljali vprašanja in pridobili pomembne informacije za svoje delo. Drug način pridobivanja podatkov je bil pregled obstoječega gradiva o destinaciji in festivalu. Tako smo uporabili dostopno literaturo, pregledali spletne strani in družbena omrežja, predvsem pa si ogledali videoposnetke festivala iz preteklih let, da smo lahko dobili vsaj približen občutek, kako je prireditev potekala ter kakšno je bilo vzdušje na festivalu. 
Nato je sledilo delo na vsebini projekta in priprava smernic za trajnostno prireditev. Študenti so bili razdeljeni v pet skupin, in sicer na skupine, $v$ katerih je bil poudarek na ekonomski, podnebni, kulturni in okoljski trajnosti ter na skupino študentov Erasmus+, ki sta pripravila povzetek $\mathrm{v}$ angleškem jeziku. $\mathrm{V}$ duhu participativnega načrtovanja so študenti predstavili svoje ugotovitve in predloge predstavnikom destinacije, in sicer je njihova dela komentiral Boštjan Misja, direktor Turizma Podčetrtek, Bistrica ob Sotli in Kozje GIZ. Predstavitve so potekale 9. 12. 2020, prav tako prek spletne aplikacije MS Teams.

Rezultat skupnega projekta je monografija »Priporočila za zelene prireditve: primer prireditve Praznik kozjanskega jabolka«, ki vsebuje poglavja različnih avtorjev. V drugem poglavju je dr. Tanja Lešnik Štuhec predstavila zeleno pametno podeželsko destinacijo s certificiranimi gastronomskimi prireditvami po modelu »Izvorno slovensko«. V tretjem poglavju Barbara Pavlakovič piše o prireditvah v turizmu, nato Mojca Bračun predstavi samo destinacijo Podčetrtek, Bistrica ob Sotli in Kozje, v petem poglavju pa mag. Valerija Slemenšek opiše Kozjanski park ter festival Praznik kozjanskega jabolka. Monografija se zaključi s projektnimi nalogami študentov, ki so obravnavali različne vidike trajnostne prireditve ter pripravili smernice za prihodnje dogodke.

Prireditve so v času pandemije doživele velik udarec, saj so bile v večini odpovedane, ostale pa so se preselile na splet. Kljub temu avtorji te monografije verjamemo, da se bodo prireditve vrnile in se ponovno odvijale »v živo«. Takrat bo še posebej smiselno slediti smernicam za trajnostne prireditve, ki ne svetujejo samo o tem, kako varovati naravo, ampak tudi zdravje in dobro počutje samih udeležencev prireditve. To pa je osnovno vodilo vseh organizatorjev prireditev. 
Poglavlje 1

\section{Zelena pametna podeželska destinacija s certificiranimi} gastronomskimi prireditvami po
modelu »Izvorno slovensko«

TANJA LEŠNIK ŠTUHEC

Lokalni prebivalci in turisti smo vedno bolj ozaveščeni in iščemo zelene trajnostne, družbeno odgovorne prakse in izkušnje na področjih nakupa pridelkov, izdelkov, storitev in doživetij. Zelene pametne podeželske destinacije bodo vedno pogostejši cilj obiska turistov z izkušnjo ukrepov zaradi epidemije covida-19, ki želijo razpršeno, varno, poglobljeno, pristno, zeleno, vključujoče, izkustveno ... doživljati tako znana kot njim še neznana območja in znamenitosti. Kolektivne blagovne znamke so pomembno orodje razvoja podeželja in $\mathrm{v}$ verige povezanih ponudnikov, ki zagotavljajo celovito visokokakovostno gastronomsko in $\mathrm{z}$ njo povezano ponudbo strategije »od vil do vilic« ter vodenih doživetij in zelenih prireditev z lokalno dodano vrednostjo. Destinacijske organizacije za management in marketing kot koordinatorice razvoja in trženja turistične in $z$ njo povezanih dejavnosti odločilno vplivajo na prepoznavnost zelenih destinacij, njihovih atrakcij, turističnih 
produktov in organiziranih prireditev. Sonaravna usmeritev z Zeleno shemo slovenskega turizma postavlja izhodišča trajnostnega, dostopnega, družbeno odgovornega in varnega doživljanja $z$ lokalno dodano vrednostjo mikrodestinacije in Slovenije kot celote. Destinacija Podčetrtek, Bistrica ob Sotli in Kozje je odličen primer zelene destinacije za turizem dobrega počutja (Slovenska turistična organizacija, 2019, 2021a) z gastronomsko in drugimi doživljajskimi spremljajočimi ponudbami, ki ciljno nagovarjajo bližnje in bolj oddaljene obiskovalce, s tradicionalnimi prireditvami, kot je Praznik kozjanskega jabolka, pa vabijo k obisku vse dni v letu.

\subsection{Zelena pametna podeželska destinacija}

Razvoj podeželja je vedno občutljiv proces trajnih in trajnostnih gospodarskih, socialnih, političnih, kulturnih in okoljskih sprememb, namenjen izključno izboljšanju kakovosti življenja lokalnega prebivalstva podeželske regije (Lane in Kastenholz, 2018), ki pogosto s svojo filozofijo sobivanja, kreativnosti in skupnega uvida celovite prihodnosti pritegne tudi radovedne turiste. Slovensko podeželje predstavlja idealen prostor za preživljanje prostega časa kot pobeg iz urbanega stresnega okolja. Podeželski turizem ne pomeni le preživljanja počitnic na kmetiji (turizem na kmetiji - turisti bivajo na kmetiji in se spoznavajo s kmečkimi opravili) oziroma agroturizma (turisti bivajo $\mathrm{v}$ hotelu ali hotelu podobnih nastanitvenih kapacitetah na podeželju in se udeležujejo raznih dejavnosti, povezanih s kmetijsko dejavnostjo), temveč je kompleksen pojav, ki vključuje ob praznovanjih, vezanih na pridelke in živilske izdelke (trgatev, praznik buč, jabolk, kakija idr.), ki so pridelani in predelani s strani kmetijskih ponudnikov, tudi počitnice $\mathrm{v}$ naravi, pohodništvo, kolesarjenje, jahanje, plezanje, plavanje $\mathrm{v}$ rekah in jezerih ter druge športnorekreativne aktivnosti, lov in ribolov, zdraviliški in zdravstveni turizem, kulturna potovanja $z$ odkrivanjem kulturne dediščne, izobraževalna in druga kreativna potovanja, pa tudi etični in ekoturizem (Lešnik Štuhec, 2021, str. 35).

Podeželske destinacije razvijajo in tržijo turizem na podeželju in ponujajo vse sestavine sodobnega turizma s poudarkom na miru, ohranjeni krajini, neposredni komunikaciji z domačini, lokalni tradicionalni in sodobni prehrani ter spoznavanju s podeželskimi opravili in praznovanji ob možnostih dostopa za vse (Svet Evrope, 2013). Ohranjena in (za)varovana narava ter kulturna dediščina, lepi razgledi, urejena in dostopna infrastruktura za rekreacijo $\mathrm{v}$ naravi ter ponudba za dobro počutje 
pomembno sooblikujejo privlačnost podeželskih destinacij, ki pritegnejo z zelenim poslovanjem ter $\mathrm{v}$ trajnostni razvoj in dostopni turizem usmerjenimi ponudniki. Digitalna tehnologija $\mathrm{z}$ možnostjo nenehnega informiranja in komuniciranja, spremljanja tokov in usmerjanja domačinov in obiskovalcev, kanaliziranega trženja in prodaje ponudbe prepoznanim ciljnim skupinam, zbiranja informacij, obdelave le-teh $\mathrm{v}$ pametne podatke in njihove uporabe za umne odločitve omogoča razvoj pametnih turističnih destinacij. Aktualnost problematike potrjuje pobuda Evropske unije (EU), ki od leta 2019 financira program »Evropska prestolnica pametnega turizma«, ki ga izvaja Evropska komisija v štirih kategorijah, in sicer: trajnost (zmagovalno mesto v letu 2020 je Göteborg, Švedska), dostopnost (Breda, Nizozemska), digitalizacija (Ljubljana, Slovenija) ter kulturna dediščina in ustvarjalnost (Karlsruhe, Nemčija), s ciljem spodbujanja pametnega turizma v Evropski uniji, krepitve destinacij in lažje izmenjave najboljših praks. Evropska komisija je organizirala dve tekmovanji in izbrala za glavni prestolnici pametnega turizma v letu 2019 mesti Helsinki (Finska) in Lyon (Francija), za leto 2020 pa Malago (Španija) in Göteborg (Švedska) (European Commission, b.d.). Primeri dobre prakse so prenosljivi na podeželske destinacije, ki pogosto vključujejo tudi parke zavarovane narave ter urejene rekreacijske površine za pohodnike in kolesarje, za katerih informiranost in trženje ponudbe odlično poskrbijo platforme za aktivnosti v naravi, kot je Outdooractive, ki ima več kot 12 milijonov uporabnikov (Outdooractive, b. d.). Z navidezno in virtualno resničnostjo postajajo atrakcije narave in kulturne dediščine vse bolj dostopne in prilagojene za poglobljena doživetja in velik izziv za druženje na podeželju.

Nagrajevanje obiskovalcev za zeleno vedenje (mehka mobilnost, raba javnega prometa $\mathrm{z}$ vozili na alternativne vire energije, bivanje $\mathrm{v}$ zelenih certificiranih nastanitvenih kapacitetah ipd.), nakupovanje z lokalno dodano vrednostjo (npr. obisk lokalnih kulturnih ustanov in prireditev $z$ enotno digitalno vstopnico, obisk lokalnih ponudnikov, nakup certificiranih izdelkov, storitev in doživetij s certifikatom kolektivne blagovne znamke destinacije), poglobljeno doživljanje pristne destinacije s pomočjo virtualne tehnologije (vodena ali samovodena pristna doživetja z lokalnimi vodniki, kustosi in izvajalci izkustvenih delavnic) in vključevanje $\mathrm{v}$ dobrodelne aktivnosti destinacije (humanitarni prispevki, prostovoljski turizem) prinašajo sinergične učinke vsem vključenim deležnikom. 


\subsection{Model znamčenja ponudbe s kolektivno blagovno znamko (KBZ) po modelu »Izvorno slovensko«}

Podeželski turizem omogoča trženje kmetijskih proizvodov na domačem dvorišču, v lastni prodajalni, na tržnici ali v spletni prodajalni, pa tudi s kratko dobavno verigo - lastno dostavo direktno gostinskim organizacijam in lokalnim delikatesnim prodajalnam. Tako je omogočena najkrajša možna pot od njive do krožnika, potrošniki pa se lahko neposredno srečajo s pridelovalci in predelovalci, spoznajo njihove zgodbe ter navežejo dolgoročne odnose. Potrdimo lahko misel, da kmetije s ponudbo pridelkov, izdelkov in storitev prebivalcev podeželskih krajev tržijo celotno pokrajino z vsemi naravnimi in kulturnimi znamenitostmi, tradicijo in posebnostmi (Bojnec in Korpar, 2005).

Za celovito in usklajeno ponudbo je nujna koordinacija destinacijske organizacije za management in marketing, ki nadgrajeno po Morrisonu (2019) izvaja naslednje naloge: (i) načrtovanje, vodenje in koordiniranje ter evalvacija vseh aktivnosti na destinaciji; (ii) skrb za strateško načrtovanje trajnostnega razvoja, dostopnega za vse; (iii) raziskovanje za potrebe sledenja turističnim tokovom, prepoznavanja trendov v turizmu, primerjanja s konkurenčnimi destinacijami (benchmark analiza) ter podjetnega odločanja managerjev turističnih in s turizmom povezanih organizacij; (iv) razvoj ponudbe privlačnih personaliziranih produktov; (v) upravljanje obiska prepoznanih ciljnih skupin turistov; (vi) marketing in promocijo; (vii) partnerstvo in team building; (viii) odnose in vključenost lokalne skupnosti in drugih deležnikov v odločanje. Kakovostna, povezana in celovito usklajena ponudba s pristno lokalno dodano vrednostjo, ki jo je mogoče zaznati kot zgodbo destinacije s številnimi podzgodbami, lahko loči eno destinacijo od druge in predstavlja najpomembnejšo konkurenčno prednost $\mathrm{v}$ primerjalni analizi destinacij.

Kolektivne blagovne znamke, vzpostavljene po modelu »Izvorno slovensko«, so v letu 2021 pomemben gradnik razvoja in trženja ponudbe 16 slovenskih destinacij, ki gravitirajo na podeželje (slika 1) in skupno pokrivajo $40 \%$ (88) občin v Sloveniji. 


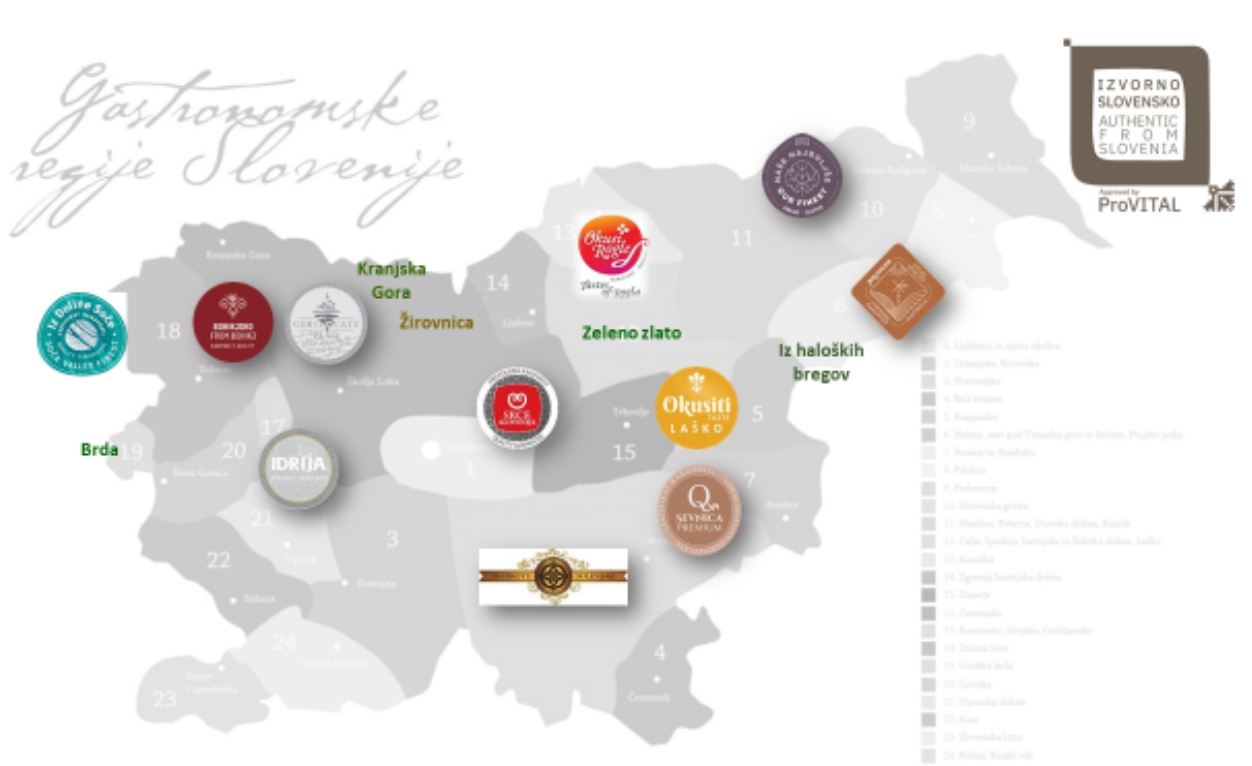

Slika 1: Lokacija slovenskih KBZ, vzpostavljenih po modelu »Izvorno slovensko« v letu 2021 Vir: Nadgrajeno po Lešnik Štuhec, 2021, str. 372.

Najgostejša mreža znamk je na območju Julijskih Alp, kjer sta trenutno vzpostavljeni dve kolektivni blagovni znamki (Bohinjsko in Bled Local selection), nastajajo pa še štiri nove, in sicer: Iz Doline Soče, Vrhunsko Kranjska Gora, Žirovnica in Brda. Največ občin je vključenih na območju Štajerske, in sicer v znamke: Okusi Rogle, Jeruzalem Slovenija, Maribor - Naše najboljše, Okusiti Laško in Sevnica Premium. Dolenjsko pokriva znamka Dobrote Dolenjske, območje od Kamnika do Šentruperta pa Srce Slovenije, znamki Idrija izbrano se priključuje tudi občina Cerkno. Kolektivna blagovna znamka Iz haloških bregov pokriva celotne Haloze, vendar še ne posluje, v nadgradnji je znamka Zeleno zlato na območju občine Žalec.

Sistem vzpostavljanja KBZ po modelu »Izvorno slovensko« temelji na štirih nivojih vzpostavljanja kakovostne ponudbe strategije »od vil do vilic« in butičnih vodenih doživetij (slika 2), ki jih ponujajo certificirane sprejemne turistične agencije. $\mathrm{Na}$ prvem nivoju se gradi primarna ponudba. Usposablja in svetuje se ponudnikom pridelkov in živilskih izdelkov, da lahko oblikujejo zgodbe z lokalno dodano vrednostjo, ki jih v svoje jedi vključijo gostinci. Na drugem nivoju se vzpostavlja lokalno prepoznavna ponudba storitev, in sicer nastanitvenih kapacitet, gastronomskih prireditev in doživetij. Tretji nivo je namenjen ambasadorjem 
kolektivne blagovne znamke, ki so glasniki zgodbe destinacije in pod eno streho združujejo več predhodno omenjenih produktov z lokalno dodano vrednostjo. Ključno vlogo igrajo sprejemne turistične agencije, ki vse predhodno vzpostavljene kategorije produktov povežejo $\mathrm{v}$ celovit turistični program, tržen po primernih kanalih in izvajan skozi mrežo specializiranih gastronomskih turističnih vodnikov. Četrti nivo je namenjen gradnji digitalnega portala, ki omogoča komuniciranje med deležniki znotraj destinacije in pritegne pozornost zahtevnih raziskovalcev gastronomije $\mathrm{v}$ ali zunaj destinacije, ki so za izjemna butična doživetja pripravljeni nameniti svoj čas in denar (Lešnik Štuhec 2021, str. 2).

\section{VERTIKALA ZNAMČENJA KBZ V SLOVENIJI PO MODELU}

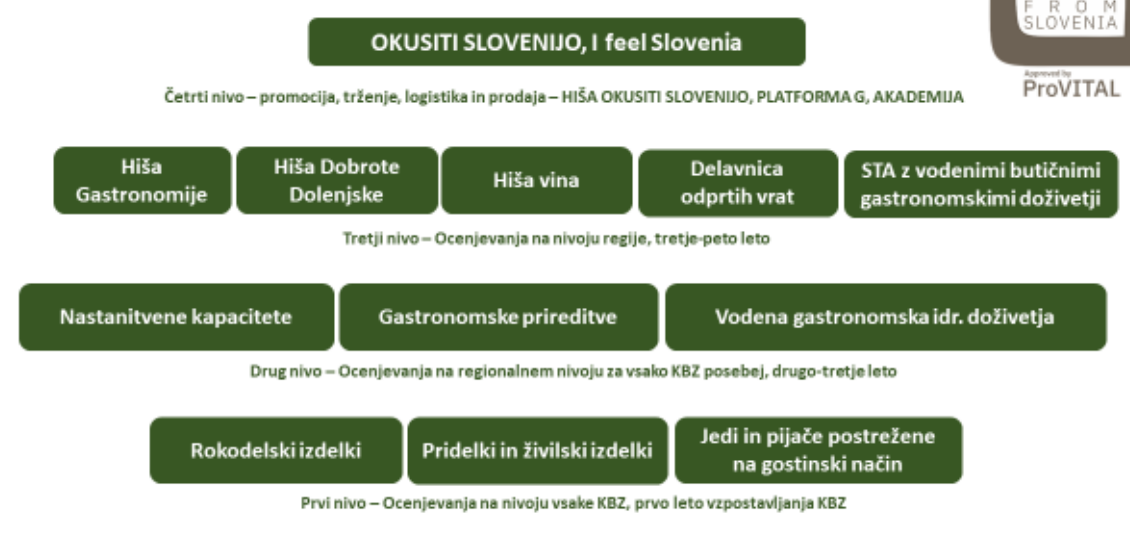

Slika 2: Nivoji vzpostavljanja kakovostne ponudbe strategije »od vil do vilic» in butičnih vodenih doživetij

Vir: Lešnik Štuhec, 2021, str. 360.

$\mathrm{Na}$ terenu je zelo močno izražena potreba po implementaciji digitalne tehnologije, ki bi: (i) povezala turistični sektor in lokalne skupnosti, (ii) omogočila celovito komuniciranje, trženje, prodajo in logistiko certificirane ponudbe $z$ javnostmi, (iii) nudila pomoč pri poglobljenem doživljanju ter (iv) evalvacijo opravljenih tokov v destinacijah. Ključna ugotovitev iz prakse je, da morajo destinacijske organizacije nadgraditi rabo tehnologij in vzpostaviti digitalno informacijsko okolje za hitrejši in učinkovitejši prenos informacij. To bi lahko zbližalo zaznavo med posameznimi deležniki različnih sektorjev in s tem pozitivno vplivalo na implementacijo ter rabo 
tehnologije znotraj destinacije (npr. intranet, stik z zunanjim okoljem), celovita destinacijska platforma pa bi bila prilagojena tudi za mobilne aplikacije in komuniciranje v družbenih omrežjih. Pri tem je treba zagotoviti izboljšanje znanja o razpoložljivosti, uporabljivosti in uporabnosti tehnologij (npr. obogatene in virtualne resničnosti, internet stvari, blockchain tehnologije, tehnologije umetne inteligence in velikih podatkovnih baz pa tudi mobilnih aplikacij in spletnih rezervacijskih sistemov (Arctur d.o.o., 2019)), zagotoviti financiranje investicij v tehnologijo (celovito platformo) ter znanje in razpoložljivost kadrov za ravnanje s tehnologijami ter dostopnost informacij za različne ciljne skupine tudi dostopnega turizma.

\subsection{Zelene gastronomske prireditve, certificirane po modelu »Izvorno slovensko«}

Hall in drugi (2003) ter Hall in Sharples (2008) izpostavljajo gastronomski turizem kot izkustveno potovanje $\mathrm{v}$ gastronomsko regijo iz rekreacijskih ali zabavnih razlogov, ki vsebuje ob obisku primarnih in sekundarnih proizvajalcev hrane tudi obisk gastronomskih prireditev, sejmov hrane, gastronomskih dogodkov, tržnic, predstavitev kuhanja ter okušanje kakovostnih pridelkov in izdelkov, pa tudi obisk restavracij ali kakršno koli drugo aktivnost, povezano s hrano. Izkustvena potovanja so povezana $\mathrm{z}$ določenim življenjskim slogom turistov. Preizkušanje, učenje od drugih kultur, pridobivanje novih znanj in spretnosti (Hall in Sharples, 2008) ter razumevanje značilnosti vodenih doživetij in gastronomskih posebnosti regij so ključni elementi izkustvenega potovanja. Kulinarične in gastronomske prireditve imajo velik potencial za prenos gastronomskih znanj in razumevanja posebnosti gastronomskih regij (World Tourism Organization and Basque Culinary Center, 2019; Bogataj, 2019; Slovenska turistična organizacija, 2018). To velja še posebej za Slovenijo, ki s 24 gastronomskimi regijami »v izjemnem kulturnem in razvojnem stičišču evropskega alpskega, mediteranskega in kraškega ter panonskega prostora« (Slovenska turistična organizacija in Ministrstvo za gospodarski razvoj in tehnologijo, 2018, str. 7) ponuja več kot 365 značilnih lokalnih in regionalnih jedi ter pijač v 3 vinorodnih deželah (na 18.544 ha, 0,8 milijonov hl vina pridela 30.000 vinogradnikov in vinarjev, ki se z dejavnostjo ukvarjajo profesionalno ali ljubiteljsko, le 2500 od teh jih vina stekleniči) (ibid., str. 23). 
Model »Izvorno slovensko« nastaja dobrih deset let kot orodje razvoja podeželja v gastronomske destinacije. Temelji na povezovanju pristopov »od spodaj navzgor« in »od zgoraj navzdok. Pobuda po vzpostavljanju skupne znamke največkrat izvira iz samih ponudnikov in njihovega zavedanja, da lahko le skupaj dosežejo prepoznavnost na trgu. Občine pogosto vzpostavijo sistem s pomočjo sredstev iz različnih sistemskih in programskih virov, upravljanje in skrbništvo kolektivne blagovne znamke in proces razvoja znamčenja pa predajo turističnim organizacijam v javnem, zasebnem ali javno-zasebnem partnerstvu (Lešnik Štuhec, 2021, str. 151). Ena od kategorij certificiranja ponudbe storitev s KBZ, vzpostavljeno po modelu »zzvorno slovensko«, so organizirane gastronomske prireditve (ibid., str. 152). Predstavljajo gonilo prepoznavnosti gastronomske destinacije tako navznoter kot s primernimi marketinškimi prijemi tudi navzven, zunaj lokalnih oz. regionalnih mej posameznih občin in destinacije kot celote.

Člani strokovne komisije za ocenjevanje organiziranih gastronomskih prireditev oblikujejo dokumentacijo za gastronomske prireditve (ibid., str. 152-153, 366), ki jo sestavljajo: (i) Pravilnik o KBZ destinacije in pogojih podeljevanja pravice do uporabe KBZ, (ii) Pravilnik o ocenjevanju kakovosti gastronomskih prireditev za pridobitev znaka kakovosti KBZ destinacije, (iii) ocenjevalni list za gastronomsko prireditev, (iv) vloga in prijavnica za gastronomsko prireditev, (v) delovni list za gastronomsko prireditev, (vi) poročilo Strokovne komisije za ocenjevanje, (vii) sklep in (viii) certifikat. Lastnik oz. upravljavec KBZ vodi arhiv dokumentacije, fototeko, videoteko ter register ponudnikov, ki je javno objavljen na spletni strani destinacije.

Organizatorji gastronomskih prireditev, ki lahko pridobijo pravico do uporabe KBZ, morajo ob posebnih izpolnjevati tudi splošne pogoje (nadgrajeno po ibid., str. 151): (i) prijavitelji morajo biti registrirane pravne ali fizične osebe za organiziranje in izvajanje prireditev, (ii) izpolnjevati morajo zakonsko določene predpise in standarde, (iii) celotna promocija, prodaja in izvajanje prireditev mora biti sledljiva, (iv) zagotavljati morajo visoko kakovost vseh povezanih dogodkov, ki sestavljajo gastronomsko prireditev, (v) izvor/poreklo gradiv, živil, postopkov izdelave izdelkov oz. izvedbe storitev in zgodb, ki so del programa gastronomske prireditve, morajo biti v določenem odstotku (določi se skupaj z delovno skupino) iz območja, ki ga pokriva KBZ oz. $100 \%$ iz območja Slovenije, razen vabljenih gostov in tekmovalcev iz mednarodnega okolja, (vi) prireditve temeljijo na kulinarični zgodbi, naravi, kulturni oz. etnološki dediščini in drugih značilnostih destinacije, (vii) 
organizatorji prireditev vključujejo lokalne ponudnike in ustvarjajo lokalno dobaviteljsko verigo ter izvajajo promocijo za prodajo njihove ponudbe s KBZ.

Upravljavec oz. skrbnik KBZ razpiše termine za ocenjevanje z vsako kategorijo produktov vsaj enkrat letno (ibid., str. 134-135). Datum za ocenjevanje prireditve je prilagojen času njenega izvajanja. Po usposabljanju, ki ga izvedejo člani strokovne komisije za ocenjevanje gastronomskih prireditev, se organizator vpiše $\mathrm{v}$ mrežo KBZ $\mathrm{z}$ vlogo in prijavi prireditev $\mathrm{v}$ postopek ocenjevanja s prijavo in izpolnjenim delovnim listom - Poslovnikom za organizacijo gastronomske prireditve. Na tej osnovi člani strokovne komisije za ocenjevanje spoznajo vsebino in vse tehnične značilnosti prireditve, organizatorji pa sistematično izvajajo in nadgrajujejo zapisano vsebino. S pravilnikom so določena merila, ki so razvidna $\mathrm{v}$ ocenjevalnem listu za ocenjevanje gastronomskih prireditev. Člani strokovne komisije za ocenjevanje pred samo izvedbo prireditve (vsaj mesec dni prej) opravijo z organizatorjem razgovor. Tako se spoznajo $z$ vsebino in programskimi sklopi ter opravijo prvo svetovanje na daljavo. Ocenjevanje same prireditve se izvede na dan prireditve. $\mathrm{Na}$ osnovi izvirnosti, originalnosti in izvedenega načrtovanega scenarija prireditve izdelajo člani strokovne komisije priporočila za nadgradnjo kakovosti gastronomske prireditve, ki so zapisana v dokumentu -Poročilo o ocenjevanju gastronomske prireditve, ki je tudi predstavljeno organizatorju prireditve.

Bogataj (ibid., str. 28) razlikuje tri temeljne skupine kulinaričnih in gastronomskih prireditev, in sicer: (i) tradicionalne kulinarične ali gastronomske prireditve, ki so se kot kontinuiteta $\mathrm{z}$ vsemi spremembami ohranile $\mathrm{v}$ današnji čas, (ii) prireditve, ki so sodobne interpretacije kulinaričnih tradicij, ter (iii) prireditve, ki so izrazite inovacije in temeljijo na sodobnih kulinaričnih in gastronomskih prizadevanjih. V postopek ocenjevanja za pridobitev pravice do uporabe kolektivne blagovne znamke po modelu »Izvorno slovensko« lahko organizatorji prijavijo štiri različne vrste prireditev, in sicer: (i) gastronomske prireditve, ki temeljijo na eni jedi oz. pijači, (ii) gastronomske prireditve, ki temeljijo na več jedeh ali skupinah jedi oz. pijač, (iii) etnološke in druge prireditve, ki imajo izrazito izobraževalni značaj (delavnice in podobno), ter (iv) splošne in druge vrste prireditev, ki imajo v svoji vsebinski zasnovi tudi kulinarične vsebine (npr. festival pesmi z motivom neke jedi). Te morajo biti zastopane v najmanj $30 \%$. 
Z ocenjevanjem se stremi k spodbujanju organizatorjev k celovitemu zagotavljanju kakovostnih gastronomskih prireditev skozi: (i) osredotočenost na rdečo nit prireditve, (ii) prepoznavanje ciljnih skupin obiskovalcev, (iii) vključevanje lokalnih ponudnikov in njihove ponudbe visokokakovostnih pridelkov, izdelkov in storitev - lokalna dobaviteljska veriga, (v) uporabo tradicionalnih običajev, receptur jedi oz. pijač s sofisticirano pripravo lokalnih jedi in pijač, (vi) ponudbo degustacij, delavnic in drugih dogodkov za povečanje prepoznavnosti gastronomije $\mathrm{v}$ povezovanju $\mathrm{z}$ gostinci, vinarji in kmetijami, (vii) oblikovanje scenarija prireditve $\mathrm{z}$ natančno načrtovanim programom, (viii) izvajanje aktivnosti, ki temeljijo na trajnostnem ravnanju, zelenem poslovanju - mehki mobilnosti in varnosti, (ix) odlično usposobljenost akterjev, (x) promocijo in prodajo prireditve skozi različne kanale, $\mathrm{z}$ zgodbami, ki razlikujejo gastronomske prireditve od podobnih $\mathrm{v}$ sosednjih destinacijah.

Glavni poudarki pri izvajanju prireditev se nanašajo na: (i) varnost ter ustrezno (videz) in higiensko urejen prostor (minimalni higienski standardi), (ii) ponudbo lokalnih in regionalnih jedi in pijač ter njihovo povezanost s tematiko prireditve scenarij, (iii) pravilno in primerno poimenovanje in označitev prireditve in ponujenih izdelkov ter storitev, (iv) ureditev prireditvenega prostora in posameznih prodajnih mest s sonaravnimi in trajnostnimi gradivi, (v) poudarjanje lokalnih zgodb živilskih izdelkov in storitev prodajalcev, (vi) glasbo, skladno z določili EU. Med zelenimi smernicami se izpostavlja: (i) soodvisnost - povezovanje ponudnikov, (ii) dostopnost za vse (tako fizično kot informacijsko, ekonomsko in družbeno), (iii) mehko mobilnost, (iv) lokalno dodano vrednost, (v) butična zelena doživetja, (vi) pozitiven vpliv na naravno in kulturno okolje, (vii) pozitiven vpliv na lokalno skupnost, (viii) pozitiven vpliv na turistično gospodarstvo, (ix) ukrepe za hitro okrevanje po epidemiji.

Program prireditve in vse promocijske aktivnosti temelijo na lokalnem oz. regionalnem povezovanju, kjer je ključno: (i) sodelovanje, soodvisnost in vključenost različnih deležnikov, (ii) povezanost doživetij v lokalne oz. regionalne mreže ponudnikov, (iii) vzpostavljanje skupne vstopnice za prevoz, prireditev, doživetja, (iv) razpršena ponudba po destinaciji za različne skupine obiskovalcev - manjše skupine (glede na nosilno zmogljivost) ter (v) enoten zemljevid in objavljen program prireditve tako v klasični kot digitalni obliki. 
Prireditev, ki je dostopna za vse ciljne skupine, zahteva načrtovan pristop $\mathrm{k}$ informiranju oz. promocijskim aktivnostim z orodji in aktualnimi informacijami za ozaveščanje. Ključna je aplikacija za prireditve, ki omogoča nenehno spremljanje dogajanja in je podprta tudi $z$ nastavljivim sistemom za osebe, ki slabše vidijo ali slišijo (povečava črk na primerni barvni podlagi, zvočni zapis ipd.). Fizična dostopnost za vse ciljne skupine omogoča dostop tudi osebam, ki imajo kakršne koli oblike gibalne oviranosti, družinam z otroškimi vozički in starejšim, ki težje hodijo, pa tudi tistim z vizualno oviranostjo - osebam, ki slabše slišijo ali vidijo (avdio vodnik, makete, indukcijska zanka za osebe s slušnim aparatom ipd.). Pozornost je treba nameniti tudi tistim, ki imajo kakršne koli težave pri prehranjevanju zaradi bolezni ali verskih in drugih prepričanj (intolerance na določena živila, bolezni, kot je diabetes ali intoleranca na gluten ali laktozo, vegani, vegetarijanci, brez svinjine ipd.), ponuditi tudi nadomestila npr. alkohola z brezalkoholnimi pijačami, da prihranimo zadrege (npr. pri pokušnjah vina je alternativa grozdni sok). Vsem starostnim skupinam je treba $\mathrm{v}$ programu pripraviti vsebine, ki jih bodo pritegnile in zadržale njihovo pozornost. To so doživetja za družine (pritegniti vse člane: oče, mama, otroci različnih starosti), starostnike, manjše homogene ali heterogene skupine, pa tudi doživetja za osebe $\mathrm{z}$ različnimi potrebami (gibalno ovirani, slepi in slabovidni, gluhi in naglušni, osebe $z$ omejitvami v razvoju idr.). Največjo pozornost je seveda treba nameniti zagotavljanju varnosti in higienskih smernic. Ekonomska dostopnost se nanaša na zagotavljanje dostopa vsem, tudi ekonomsko šibkejšim, in sicer z brezplačnimi vstopnicami ali programi podeljevanja vstopnic z npr. nagradnimi vprašanji.

Vključevanje mehke mobilnosti se nanaša na vzpostavitev: (i) sistema eko-parkirišč in polnilnic za e-vozila, (ii) alternativnih oblik javnega prevoza iz večjih mest in krajev na poti, (iii) združevanja dostavnih vozil za dostavo na prireditev in dostave $z$ alternativnimi prevoznimi sredstvi, (iv) urejenih parkirišč zunaj centra dogajanja, (v) enotne vstopnice za prevoz oz. parkirišče in prireditev, ki jo je mogoče kupiti na daljavo, na začetku poti in na sami lokaciji. Da bi dosegli kar največjo možno lokalno dodano vrednost, naj program prireditve vključuje: (i) poglobljeno vključevanje tradicije za pristnost in razlikovanje od drugih visokokakovostnih prireditev (narava, lokalna oz. regionalna kultura - leposlovje, glasba, kulinarika, jezik idr.), (ii) mrežo lokalnih dobaviteljev s certificirano visokokakovostno ponudbo, (iii) enotno urejenost prostora in izvajalcev, kar predstavlja lokalno zgodbo s poudarjeno osrednjo tematiko, (iv) alternativno lokacijo v primeru slabega vremena, (v) enotno 
zgodbo $-\mathrm{z}$ rdečo nitjo prireditve, ki je zapisana, predstavljena in evalvirana ter nadgrajena $\mathrm{v}$ programe prireditve za vsaj naslednjih 5 let.

Za doseganje butičnosti zelenih doživetij (Slovenia Unique Experiences) naj program prireditve vključuje: (i) zelena butična doživetja za različne ciljne skupine obiskovalcev glede na rdečo nit prireditve, (ii) profesionalno izvedene vodene oglede, pokušnje, delavnice (odlično usposobljeni inovativni in kreativni izvajalci), (iii) ponudbo, sestavljeno iz lokalne verige ponudnikov, (iv) pristen ambient, opremo izvajalcev, programe pokušanj ..., ki so prilagojeni zgodbi prireditve in ciljni/ciljnim skupini/skupinam, (v) mehko mobilnost, (vi) biološko razgradljivo embalažo, (vii) vključenost za samouresničevanje - novo pridobljene kompetence s pokušnjami, delavnicami, ogledi, (viii) obljubo po povratni informaciji o izvedeni prireditvi skozi aplikacijo prireditve, ki omogoča njeno nenehno sledenje.

Pozitiven vpliv prireditve na okolje se nanaša na: (i) vpliv prireditve na naravo in kulturno dediščino ter nesnovno dediščino, ki jo obujajo društva in posamezniki, (ii) izgrajeno splošno in turistično infrastrukturo, (iii) ločevanje odpadkov z ekološkimi otoki in ozaveščanje o ločevanju odpadkov, recikliranju ipd., (iv) skrb za ohranjanje in plemenitenje okolja s premišljeno uporabo lokalnih (ekološko pridelanih) živil in gradiv, biorazgradljivih materialov (drobni inventar in embalaža), ekoloških čistil in recikliranega toaletnega papirja, zelene energije in vode na toaletah z razpršilci, mehke mobilnosti in javnega prevoza ter urejenih postajališč/parkirišč, lokalnih zaposlenih ter vzpostavljenih kratkih verig dobaviteljev za čim nižji ogljični odtis.

Pozitiven vpliv prireditve na lokalno skupnost se kaže skozi: (i) skrb za kakovost življenja lokalnih prebivalcev (lokalna zaposlitev, podjetniške iniciative, urejena infrastruktura ...), (ii) zagotovljen nizek ogljični odtis in s tem relativno čist zrak, vodo, rodovitno prst, lepe gozdove in prepoznano krajino, (iii) doživetja lokalnih prebivalcev, ki so pomembni obiskovalci prireditev, (iv) ozaveščanje vseh ciljnih skupin o pomenu narave in kulturne dediščine, rekreacije, zdravega načina življenja, druženja ... (v) prepoznavnost lokalne skupnosti v širšem prostoru, ter (vi) doniranje odvečne hrane ter vstopnic in doživetij pomoči potrebnim lokalnim prebivalcem. 
Pozitiven vpliv prireditve na turistično gospodarstvo se navezuje na: (i) optimizacijo stroškov za promocijo v socialnih medijih in tehnologijah, ki temeljijo na aplikacijah za komuniciranje $z$ obiskovalci, (ii) promocijo, trženje in prodajo celovite ponudbe $\mathrm{z}$ lokalno dodano vrednostjo, ki vabi k naslednjemu obisku, (iii) širjenje sezone in ustvarjanje nočitev v obdobjih nizke sezone, (iv) spodbujanje ponudnikov k ponudbi izjemnih doživetij za dodano vrednot razpršene ponudbe in prihodka po vsej destinaciji, (iv) družbeno odgovorno vedenje ponudnikov, ki vključuje tudi poslovanje, skladno $\mathrm{z}$ okoljskimi shemami in pristopom $\mathrm{v}$ Zeleno shemo slovenskega turizma.

Nova realnost po pandemiji covida-19 nas opominja $\mathrm{k}$ pomenu: (i) digitalne promocije in trženja $z$ virtualno resničnostjo (filmi, odlične fotografije ipd.), (ii) krajšanja potovalnih poti na do $500 \mathrm{~km}$ (osebno vozilo) in s tem večji privlačnosti gastronomskih prireditev, (iii) manjšanja številčnosti skupin (na potovanju in $\mathrm{v}$ sklopu programov prireditev) in potovanj v sklopu družine oz. posamezno in s tem potrebo po razpršenosti ponudbe delavnic, pokušanj, vodenih ogledov do maksimalno 10 oseb, (iv) povpraševanja po odličnih, poglobljenih in vključujočih izkustvenih doživetjih za izbrane ciljne skupine (družina, pari, majhne homogene skupine), (v) inovativnosti in kreativnosti izvajalcev doživetij, (vi) celovite ponudbe, ki omogoča razpršitev prihodka po destinaciji, (vii) pristnosti vrhunske gastronomije, ki je odločilna pri odločanju za obisk destinacije, (viii) varnosti in higiene kot standardov za zaupanje in prihod $\mathrm{v}$ destinacijo.

\subsection{Zaključek}

Če kdaj, je zdaj čas, da povežemo znanje, izkušnje, entuziazem in politično voljo ter oblikujemo enovite, vključujoče, zelene, pametne podeželske destinacije, kjer skupaj delujejo naravovarstvo, kmetijstvo, gozdarstvo, turizem in druge pomembne gospodarske dejavnosti in raznolike iniciativne skupine ter posamezniki. S pristnimi zgodbami širnih in neukrotljivih gozdov, čisto vodo in zrakom, krasnimi razgledi, privlačno urejenimi (coniranje in režimi ravnanja) atrakcijami za doživljanje narave in kulturne dediščine ter rekreacijo $\mathrm{v}$ zelenem okolju, inovativnimi ekološkimi kmetijami in kratkimi prehranskimi dobavnimi verigami, programi gastronomskih vodenih doživetij in organiziranih prireditev, razlikovalnimi rokodelskimi in izdelki industrijskega oblikovanja (npr. les, kamen) ter gostoljubnimi in kreativnimi ljudmi, ki preudarno koristijo naravne danosti, se dopolnjujeta stoletni stik človeka in narave 
slovenskega podeželja. Samo povezani lahko ustvarjamo in omogočamo odlične pogoje za kakovostno bivanje in delo. Prav tak kreativen »od spodaj navzgor« in »od zgoraj navzdol« voden proces razvoja in trženja lokalne/regionalne ponudbe z dolgoročno sliko prihodnosti, ki ga ponuja sistem vzpostavljanja kolektivnih blagovnih znamk po modelu »Izvorno slovensko«, običajno pritegne v zelene destinacije prave obiskovalce. Tiste, ki radovedno raziskujejo in se pustijo razvajati s specializirano gastronomsko ponudbo po meri oblikovanih doživetij ter odlično načrtovanih in $z$ vabljivimi programi oglaševanih gastronomskih prireditev, ki leto za letom kličejo k obisku. Bistveno je, da ob pristni naravi vključujejo bogato kulturo in dediščino, okuse tradicionalne in sofisticirane gastronomije ter $z$ izjemno zgodbo s po-okusom (nakupom za domov) navdihnejo in presežejo obljubljene izkušnje. Tako se oblikuje prostor za pobeg od stresnega sveta $\mathrm{v}$ zeleno pribežališče za oddih, druženje ob gastronomskih prireditvah, izobraževanje, kreativnost in rekreacijo $\mathrm{v}$ podeželskem naravnem okolju. Vloga destinacijskih organizacij je ključna. Povezati morajo ponudnike, poskrbeti za visokokakovostno ponudbo od njive do krožnika in vodenih doživetij $\mathrm{v}$ naravnem okolju ter s primernimi digitalnimi in klasičnimi orodji doseči prepoznane ciljne skupine gostov, ki bodo pomembno sooblikovali gastronomske prireditve $\mathrm{v}$ zelene, pametne in pristne ter $\mathrm{s}$ komentarji $\mathrm{v}$ medmrežju postavili destinacijo na gastronomski zemljevid Evrope. Vse pogoje za ta korak ima tudi destinacija Podčetrtek, Bistrica ob Sotli in Kozje. 
Poglavlje 2

\section{Prireditve v turizmu}

BARBARA PAVLAKOVIČ

Turizem ponuja turistom veliko različnih zanimivih elementov, ki jih opisujemo kot znamenitosti ali privlačnosti. In čeprav so ljudje že v antiki potovali zato, da bi videli določene posebne elemente, se je sodobno pojmovanje turističnih znamenitosti razvilo šele v obdobju po 2. svetovni vojni s pojavom modernega turizma (Page in Connell, 2014). Vodeb (2018) povzema različne definicije znamenitosti od tega, da predstavljajo najpomembnejši element turističnega proizvoda, da so glavni motivator in generator turističnih potovanj in obiskov, da so turistične privlačnosti sestavni deli destinacije, ki jih je treba načrtovati in upravljati. Vsem pa je skupno to, da obstaja imenovanost vira oz. znamenitosti, da gre za značilnosti, ki so zanimive za obiskovalce (vzbujajo interes in predstavljajo motiv obiska), opazna je potreba po managementu (načrtovanje in upravljanje) ter povezanost $\mathrm{s}$ turističnim proizvodom/destinacijo (ibid.). Edelheim (2015, str. 14) prav tako povzema definicije in navaja, da jim je skupno to, da »se nanašajo na objekte, prostore, kraje in lastnosti obvladljivih subjektov«.

Turistične znamenitosti lahko razdelimo v več skupin. Goeldner in Ritchie (2003) delita znamenitosti $\mathrm{v}$ pet skupin, ki zajemajo: kulturne znamenitosti, naravne znamenitosti, dogodke, rekreacijo in zabavo. Medtem pa Ritchie in Crouch (2003) 
predlagata delitev $\mathrm{v}$ sedem skupin: pokrajina in podnebje, kultura in zgodovina destinacije, mešanica aktivnosti, posebni dogodki, zabava, določeni elementi superstrukture in tržne vezi oz. področje človeških odnosov. Najbolj razširjena in tudi sprejeta klasifikacija turističnih privlačnosti je Swarbrookova (2002), ki jih deli na štiri skupine:

- naravne privlačnosti (plaže, jame, reke, jezera, gozdovi, gorovja ... );

- umetne privlačnosti, ki niso bile zgrajene za turiste (sakralni objekti, arheološka najdišča, spomeniki);

- umetne privlačnosti, ki so zgrajene za turiste (tematski parki, zabaviščni parki, marine, botanični vrtovi, safari parki, terme, igralnice, vodni parki);

- posebni dogodki (trgi in sejmi, festivali, športni dogodki, verski dogodki).

\subsection{Dogodki oziroma prireditve}

Po pregledu zgornjih delitev lahko ugotovimo, da avtorji v prav vsaki delitvi kot posebno vrsto turističnih znamenitosti izpostavijo dogodke oziroma prireditve, ki tako postanejo ena temeljnih privlačnosti v turizmu. Dogodke oziroma prireditve so Allen in drugi (2011, str. 11) opredelili kot »specifične rituale, predstavitve, izvedbe ali praznovanja, ki so načrtovani in ustvarjeni, da obeležijo posebno priložnost ali da dosežejo določen družbeni, kulturni ali organizacijski cilj«.

Dogodki so eden najhitreje rastočih segmentov v turizmu, ki zajemajo vse od mega dogodkov (npr. olimpijske igre, svetovna prvenstva $\mathrm{v}$ različnih športih, svetovne razstave) do lokalnih prireditev in festivalov kulturne, športne, zabavne, prodajne, dobrodelne ali kakšne druge narave. Dogodki so lahko občasni (koncerti, občasna športna tekmovanja ...) ali redni (tradicionalni pustni karnevali, vsakoletni festivali ...), ki se $\mathrm{v}$ določenih rednih intervalih izvajajo na istem prostoru (Holloway in Humphreys, 2016). Pri tem pa se prireditve med seboj razlikujejo tudi po dolžini trajanja (od nekaj ur do več mesecev). In čeprav vemo, da so dogodke organizirali že $\mathrm{v}$ antičnem času, se je število udeležencev prireditev izrazito povečalo prav $\mathrm{v}$ sodobnosti, saj imajo ljudje več prostega časa, več razpoložljivih finančnih sredstev, prav tako pa je tudi več upokojencev, ki z udeležbo na dogodkih zapolnijo svoj čas (Coban, 2016). 
Načrtovane dogodke oziroma prireditve lahko opredelimo kot edinstvene prostorsko-časovne pojave zaradi vedno drugačnih interakcij med lokacijo, programom, udeleženci in organizatorji (Getz, 2008). Prav iz tega izhaja privlačnost dogodkov, saj niso nikoli enaki in če želi oseba polno doživeti dogodek, mora biti na dogodku prisotna. Skoultsos in Tsartas (2009) sta bolj naklonjena definiciji, ki prireditve opiše kot enkratne ali neredno ponavljajoče izvedbene dejavnosti zunaj rednih programov organizatorjev, ki obiskovalcem pomenijo način sprostitve ali kulturno oziroma družabno doživetje, ki nadgradi vsakodnevne dogodke. Dogodke oziroma prireditve lahko razvrstimo v več kategorij, in sicer na osnovi njihovega namena in programa (slika 3), ki lahko zajemajo na primer javna praznovanja, tekmovanja, zabavo, razvedrilo, posel, druženje ... (Getz, 2005). Kategorije pa lahko tudi združimo in tako nastanejo štiri osnovne skupine dogodkov: poslovni, zabavni, športni in kulturni dogodki (Getz in Page, 2016).

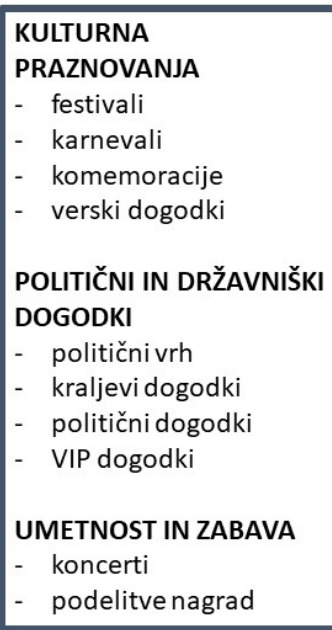

\begin{tabular}{|c|}
\hline $\begin{array}{l}\text { POSEL IN TRGOVANJE } \\
-\quad \text { sestanki, konvencije } \\
\text { - } \quad \text { poslovne predstavitve } \\
\text { in razstave } \\
\text { - } \\
\text { sejmi, tržnice }\end{array}$ \\
\hline $\begin{array}{l}\text { IZOBRAŽEVANJE IN } \\
\text { ZNANOST } \\
-\quad \text { konference } \\
-\quad \text { seminarji } \\
-\quad \text { klinike }\end{array}$ \\
\hline
\end{tabular}

\begin{tabular}{|l|}
\hline $\begin{array}{l}\text { ŠPORTNA TEKMOVANJA } \\
\text { - }\end{array}$ \\
amaterska / \\
profesionalna \\
- $\begin{array}{l}\text { za gledalce / za } \\
\text { udeležence }\end{array}$ \\
REKREACIJA \\
- šport ali igre za zabavo \\
$\begin{array}{l}\text { ZASEBNI DOGODKI } \\
\text { - poroke } \\
\text { - zabave } \\
\text { - druženja interesnih } \\
\text { skupin }\end{array}$ \\
\hline
\end{tabular}

Slika 3: Tipologija dogodkov Vir: Povzeto po Getz, 2005.

Med prireditvami so najbolj izpostavljeni prepoznavni dogodki (ang. »hallmark events«), ki so opredeljeni kot pomembni enkratni ali ponavljajoči se dogodki katere koli zvrsti prireditev, organizirani in trženi z namenom postavitve destinacije na turistični zemljevid oziroma, da si zagotovi visoko prepoznavnost na turističnem trgu (Hall, 1989). Quick (2020) meni, da so tako tesno povezani s samo destinacijo, njeno identiteto ter etosom, da so postali sinonim za ime lokacije. To niso samo 
veliki dogodki, ampak tudi manjše prireditve, ki so značilne za neko destinacijo in tako postanejo prepoznavni element v trženju turistične destinacije. Dogodki in prireditve pa niso samo turistična privlačnost, ampak imajo tudi vlogo povezovalca lokalnih skupnosti, z njihovo pomočjo oživljamo urbano okolje, razvijamo kulturo ali gradimo nacionalno identiteto (Getz, 2008).

V sodobnem času so dogodki doživeli močan udarec, saj so bili zaradi pandemije covida-19 skoraj v celoti odpovedani ali preseljeni v virtualna okolja. Kljub temu je na destinacijah močna želja po obuditvi dogodkov in ponovnem zagonu prireditvenega turizma. Za prihodnji razvoj dogodkov oziroma prireditev se nakazujejo naslednji trendi (Getz in Page, 2016; Coban, 2016):

- OBLIKOVANJE PORTFELJA DOGODKOV: Destinacije se ne bodo osredotočale na samo en osrednji dogodek, ampak bodo ponujale več različnih dogodkov skozi celotno leto, kar bo ustvarilo sinergijo dolgoročnih (ekonomskih) učinkov in pomagalo širiti turistično sezono.

- INTERESNI PRIREDITVENI TURIZEM: Dogodki se bodo prilagodili posebnim interesom obiskovalcev, zato bo več specifičnih dogodkov glede na vsebino. Obiskovalcem bodo ponujali personalizirano doživetje.

- OCENA VPLIVA PRIREDITEV: Pri organizaciji dogodkov bo pomemben tudi vpliv, ki ga dogodek povzroči ne samo na ekonomski strani, ampak tudi v smislu družbenega kapitala, vrednot, ogljičnega odtisa in sodelovanja deležnikov.

- TRAJNOST: Prireditve morajo postati trajnostne, pri tem pa še posebej neškodljive za naravo.

- RAZVOJ TEHNOLOGIJE: S pojavom pandemije so se razširili digitalni dogodki, webinarji, virtualne konference in ponudba virtualne resničnosti, ki pa so bili v zametkih ponujeni tudi že pred pandemijo.

- IZOBRAŽEVANJE: Dobre prireditve se gradijo na znanju, zato je potrebno nenehno izobraževanje in nadgrajevanje znanja o organizaciji in izvedbi dogodkov. 


\subsection{Prireditveni turizem}

Dogodki so v turizmu še posebej dobrodošli, saj lahko z njimi podaljšamo sezono v mirne dele leta, $z$ njihovo pomočjo gradimo na podobi destinacije, krepimo povezanost prebivalcev ter poskrbimo za večje ekonomske prihodke destinacije, delovna mesta in bolj razvito turistično infrastrukturo (Goeldner in Ritchie, 2003; Skoultsos in Tsartas, 2009). Iz tega izhaja prireditveni turizem, ki ga lahko opišemo kot razvoj in trženje načrtovanih dogodkov, ki jih zaznamo kot turistične privlačnosti, pospeševalce, animatorje, ustvarjalce podobe in tržnike destinacije, sploh v primeru, če so dogodki namenjeni samo za turiste (Getz, 2014).

Prireditveni turizem ima lahko zgoraj omenjene pozitivne učinke, prav tako pa tudi negativne učinke, kot so zvišanje cen med dogodkom, povečana stopnja kriminala ali kulturni šok ob stiku domačinov in obiskovalcev (Skoultsos in Tsartas, 2009). Vse te učinke sta avtorja združila v pet skupin: ekonomski, turistični, okoljski, psihološki in politični učinki. Van der Wagen in White (2010) izpostavljata tri skupine učinkov prireditvenega turizma, in sicer družbene, okoljske in ekonomske. Pri vseh gre lahko za pozitivne ali negativne učinke. Še posebej pa mora prireditveni turizem slediti načelom trajnosti ter jih upoštevati pri organizaciji in upravljanju dogodkov. Tako je pomembno, da organizatorji poskrbijo za ustrezen prevoz, zavarujejo občutljive dele prireditvenega prostora, poskrbijo za odpadke in pri tem tudi izobražujejo udeležence, delujejo etično do vseh vpletenih, podajajo verodostojne informacije o dogodku, poskrbijo za varnost in zdravje ter sledijo zakonskim določbam (Coban, 2016).

Pri izvajanju prireditvenega turizma moramo biti pozorni na različne nivoje razumevanja in upravljanja dogodkov. $\mathrm{Na}$ sliki 4 so prikazane osnovne značilnosti dogodkov, ki jih moramo upoštevati pri njihovem oblikovanju, trženju in izvedbi, povzete pa so po osnovnih karakteristikah turističnih znamenitosti na splošno (Leask, 2008 v Edelheim, 2015; Waver in Lawton, 2010 v Edelheim, 2015). 


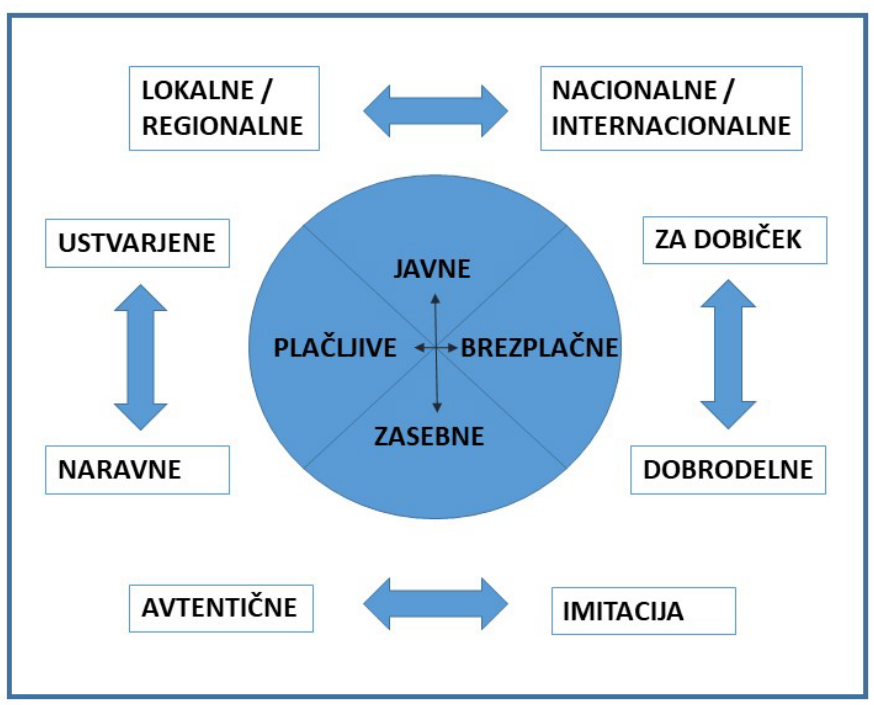

Slika 4: Lastnosti prireditev

Vir: Prirejeno po Leask, 2008 (v Edelheim, 2015) ter Waver in Lawton, 2010 (v Edelheim, 2015).

Panoga, ki se ukvarja z izvajanjem prireditvenega turizma, se imenuje upravljanje oziroma management prireditev (ang. »event management»). Gre za dejavnost, ki oblikuje, izdela in upravlja načrtovane dogodke, kot so festivali in praznovanja, zabavni in rekreativni dogodki, politične in državniške prireditve, znanstveni, športni, umetniški in poslovni dogodki (sestanki, konvencije, sejmi in razstave), kakor tudi zasebni dogodki (na primer rituali prehoda, zabave in družabni dogodki) (Getz, 2008). Coban (2016) navaja več različnih definicij managementa prireditev, ki v osnovi prav tako poudarjajo organizacijo, koordinacijo in upravljanje dogodkov, da bi dosegli zastavljene cilje.

Quick (2020) je faze načrtovanja dogodka razdelila $\mathrm{v}$ načrtovalno, izvedbeno in poprireditveno fazo. Tako koraki managementa prireditev zajemajo (Van der Wagen in White, 2010):

- določitev namena in ciljev dogodka ter obsega (trajanje, datum, ura, razpoložljiva sredstva);

- oblikovanje koncepta in teme dogodka, priprava formata (lokacija in infrastruktura), določitev deležnikov (obiskovalci, sodelujoči); 
- pripravo in izvedbo dogodka (komunikacija, vsebinska ponudba, tehnika, okras, gostinska ponudba, parkirišča, zagotavljanje varnosti ...);

- preverjanje in ocenjevanje izvedenega dogodka.

Slovenska turistična organizacija umešča dogodke in s tem prireditveni turizem znotraj širšega koncepta kulturnega turizma. Doma in mednarodno prepoznane festivale in dogodke so razdelili v štiri kategorije, ki imajo promocijski in razvojnoproduktni potencial ter pokrivajo štiri letne čase (Slovenska turistična organizacija, 2017). To so pustovanje (na Ptuju in drugje po Sloveniji), poletni festivali (Ljubljana festival, Festival Lent in drugi poletni festivali), martinovanje (pri najstarejši trti na svetu v Mariboru ter drugod) ter advent in veseli december (žive jaslice v Postojnski jami, jaslice po celi Sloveniji, sejmi in dogodki v mestnih jedrih). Prireditve so razvrstili $\mathrm{v}$ naslednje podkategorije: glasbeni festivali, gledališki festivali, dogodki vizualne umetnosti, multidisciplinarni festivali, filmski, plesni, literarni, oblikovalski, arhitekturni festivali, festivali intermedije in festivali nesnovne kulturne dediščine. Največ je glasbenih prireditev, sledijo pa jim gledališki festivali, ki so zaradi jezikovnih preprek le izjemoma primerni za tuje turiste. Številčno gledano je največ dogodkov v poletnih mesecih, festivalsko najšibkejši meseci pa so januar, februar in december. Dogodki so zanimivi tudi za turistične vodnike v tiskani ali spletni obliki, tako da imajo objavljen seznam prireditev, na primer v Lonely Planet, Insight Pocket Guide, DK Eyewitness Travel Guide, The Rough Guide, Beadeker (ibid.).

\subsection{Prireditve in podeželje}

Raziskave so pokazale, da obstajajo tri vrste dogodkov, ki prispevajo k trajnostnemu razvoju lokalnega okolja. To so (i) domači festival, kjer gre za manjšo prireditev, vodeno s strani prostovoljcev; (ii) turistični festival, ki je namenjen privabljanju obiskovalcev za spodbujanje lokalnega gospodarskega razvoja; (iii) festival »velikega poka«, ki kot tržno orodje spodbuja druge tržne dejavnosti na destinaciji (O’Sullivan in Jackson, 2002, str. 331). Za podeželsko okolje je najbolj primeren domači festival, saj gre za manjši dogodek, ki ga obišče manjše število ljudi, njegov namen pa je okrepiti kulturno in zabavno ponudbo kraja za prebivalce in obiskovalce. Če želimo doseči bolj opazne ekonomske učinke, pa lahko podeželska destinacija ponudi tudi turistični festival, če k organizaciji pristopi lokalna uprava (npr. občina, zavod za turizem in podobno). 
Organizacija podeželskih dogodkov ima več različnih namenov od ustvarjanja prihodka, ponujanja zabave, oblikovanja podobe in identitete destinacije do ohranjanja lokalne dediščne (Skoultsos in Tsartas, 2009). Vendar pa je najpomembnejši cilj povezovanje in vključevanje lokalne skupnosti, saj samo tako skupnost raste in se razvija, zato bi se morali organizatorji dogodkov na podeželju osredotočiti na samo lokalno skupnost (Moscardo, 2007). Šele potem pridejo do izraza ekonomski učinki, ki pa prevzamejo samo pomožno vlogo v ekonomski sliki podeželske destinacije. Skoultsos in Tsartas (2009) pišeta, da so v raziskavi podeželskih dogodkov ugotovili, da turisti porabijo največ denarja za prenočitev, hrano in pijačo. Posledično imajo največ dobička lokalne restavracije, drugi ponudniki hrane in pijače ter ponudniki prenočitvenih kapacitet; sledijo jim ponudniki zabavnih vsebin, trgovine, ponudniki znamenitosti $\mathrm{z}$ vstopnino ter avtomobilski servisi in bencinske črpalke. Prav tako so v tej študiji ugotovili, da je polovica obiskovalcev rednih in da se večkrat vračajo na dogodek (ibid.).

\subsection{Trajnostna prireditev}

Načela trajnosti zajemajo skrb za okolje, družbo in kulturo ter ekonomsko področje, pri čemer skrbno in odgovorno ravnamo $\mathrm{z}$ vsemi viri, ki jih uporabljamo. V preteklosti so se raziskovalci posvečali predvsem učinkom na ekonomsko področje, vendar je zdaj v ospredju koncept trojnih spodnjih mej (ang. »triple bottom line«), ki ocenjuje ekonomske, družbene in okoljske učinke (Collins in Cooper, 2017).

"Trajnostni dogodek je zasnovan, organiziran in izveden na način, ki zmanjšuje potencialne negativne vplive in hkrati koristno deluje na gostiteljsko skupnost in vse vpletene« (United Nations Environment Programme, 2012, str. 1). Trajnostni dogodki vključujejo družbeno pravična načela na vseh raveh organizacije in izvedbe dogodka; od zgodnjih faz načrtovanja, poteka dogodka, do evalvacije po dogodku (The international centre, b. d.). Pri tem upoštevajo načela (United Nations Environment Programme, 2012):

- dostopnosti in vključenosti za vse,

- zagotavljanja varnega vzdušja,

- minimalnih negativnih vplivov na okolje,

- spodbujanja zdravega življenja,

- promocije odgovorne rabe virov, 
- ustvarjanja koristi za prihodnost,

- zagotavljanja odličnosti izkušenj strank,

- spodbujanja bolj trajnostnega vedenja.

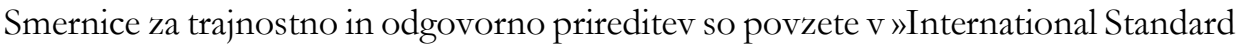
ISO 20121:2012, Event sustainability management systems« (ISO, b. d.). Prav tako pa so kriterije za izvedbo trajnostnih prireditev določili člani IAMLADP (International Annual Meeting on Language Arrangements, Documentation and Publications), in sicer 8 kriterijev, ki morajo biti vsi doseženi, če želimo dogodek imenovati trajnosten (United Nations Environment Programme, 2012, str. 6):

(i) Prizadevanje za zmanjšanje emisij toplogrednih plinov, ki bi nastali zaradi udeležbe na konferencah, in podpora nadomeščanju neizogibnih emisij.

(ii) Izvajajo se postopki za zmanjšanje porabe vode, energije, materialov in drugih virov.

(iii) Vzpostavljeni so ukrepi za zmanjšanje nastajanja odpadkov in za njihovo ponovno uporabo, reciklažo in/ali spremembo namembnosti neizogibnih odpadkov.

(iv) Pri nakupu blaga in storitev za dogodek so okoljski in družbeni vplivi njihovega življenjskega cikla vključeni v nakupno odločitev.

(v) Družbena in okoljska načela se uporabljajo skozi celotno izvedbo dogodka, da se zmanjša škoda za okolje ter zagotovi dostopnost, vključenost in dobro počutje vseh udeležencev in osebja.

(vi) Sprejeti so ukrepi za spodbujanje gospodarskih, socialnih in okoljskih koristi za lokalno skupnost, zmanjšajo se motnje.

(vii) Prizadevanje za večjo ozaveščenost, informiranje in vključevanje ustreznih deležnikov, vključno z udeleženci, delovno silo, lokalnimi gostitelji, regionalnimi in nacionalnimi oblastmi, sponzorji, skupinami civilne družbe, nevladnimi organizacijami, podjetji in tehničnimi strokovnjaki, da bi izpolnili in podprli zgoraj navedena načela.

(viii) Vzpostavljen je sistem poročanja, ki omogoča komunikacijo, ocenjevanje in vrednotenje "procesov, pobud in rezultatov trajnostnih dogodkov«. 
Kriteriji trajnosti se uporabijo za različna področja organizacije in izvedbe dogodka.

To so (The international centre, b. d.):

- komuniciranje in trženje,

- hrana in pijača,

- razstave in razstavljavci,

- namestitev,

- prevoz,

- informacijska tehnologija,

- nabava,

- okraševanje in urejanje lokacije,

- energetska učinkovitost.

Pomemben steber trajnostnega delovanja je skrb za okolje in naravo, na kar moramo biti pozorni tudi pri dogodkih. Tako moramo skrbeti za na primer odpadke, porabo energije in kanalizacijske odplake. Pri večjih dogodkih za to poskrbi najeto podjetje, ki je specializirano za dovoz in čiščenje zunanjih stranišč, za postavitev ustreznega števila in pravočasen odvoz košev za ločeno zbiranje smeti in podobno (Van der Wagen in White, 2010). Skrb za čistočo pa je povezana tudi s skrbjo za varnost in zdravje obiskovalcev in sodelujočih, saj si ne želimo raznih okužb in bolezni zaradi odpadkov ali odplak. Način, kako se merijo okoljski vplivi dogodkov, je tudi merjenje ekološkega odtisa.

Organizatorji dogodkov so postali bolj trajnostno ozaveščeni v zadnjih 20 letih, kot cilj pa si je panoga zadala, da postane »zero waste«, kar pomeni, da bodo morali na prireditvah uporabljati le vire, ki jih je mogoče reciklirati (Quick, 2020). »Zero waste« je strategija, s katero se želimo znebiti odpadkov, ne pa z njimi zgolj upravljati. Zato odpadke pazljivo načrtujemo že od začetka načrtovanja prireditve, da uporabimo samo materiale, ki jih je možno ponovno uporabiti, reciklirati ali kompostirati (United Nations Environment Programme, 2012). V Sloveniji Društvo Ekologi brez meja (2016) podeljuje naziv »Zero Waste prireditev« ali »Prireditev z manj odpadki« za dogodke, ki sledijo načelom in ločeno zbirajo odpadke (pri "Zero Waste prireditvi« mora biti dosežena stopnja $90 \%$ ločeno zbranih odpadkov). 
Poleg tega da s skrbjo za naravo koristimo splošnemu stanju okolja, hkrati zaznamo še druge učinke: finančne ( $z$ varčevanjem z viri prihranimo sredstva za te izdatke, lahko smo upravičeni do subvencij ali drugega financiranja, spodbudi se večje zanimanje za nove dogodke), promocijske (pozitivna podoba in boljši ugled) in družbene učinke (trajnostni dogodek zagotovi nova delovna mesta, boljše delovne pogoje in vključenost skupnosti), spodbudimo pa lahko tudi razvoj inovacij na področju trajnosti in ozaveščamo o pomenu trajnosti (United Nations Environment Programme, 2012; The international centre, b. d.). 
Poglavlje 3

\section{Predstavitev destinacije Podčetrtek, Bistrica ob Sotli in Kozje}

MOJCA BRAČUN

Turistična destinacija na področju Obsotelja in Kozjanskega vključuje tri občine: Podčetrtek, Bistrica ob Sotli in Kozje ter se trži pod destinacijsko znamko Podčetrtek (Občina Kozje, 2021; Občina Podčetrtek, 2017; Občina Bistrica ob Sotli, 2021). Destinacija s svojimi $181,4 \mathrm{~km}^{2}$ tako predstavlja manjše regionalno območje, ki pa kljub svoji majhnosti s strateškim pristopom oblikuje svojo enovitost.

Stopnja razvoja turizma je zelo visoka. Pestra ponudba temelji predvsem na naravnih danostih - tu prevladujeta termalna voda in neokrnjena narava. Destinacija je bogata tudi na področju kulturnih virov in $s$ turistično infrastrukturo, ki je visokokakovostna. Čeprav destinacija razpolaga z zelo majhnim odstotkom površine Slovenije $(>0,5 \%)$, se v turističnem smislu uvršča med uspešnejše in pomembnejše turistične regije. Glavnino turističnega prometa ustvari občina Podčetrtek, pomemben delež pa tudi občina Kozje s Kozjanskim regijskim parkom (Javni zavod Kozjanski Park, 2012; Slovenska turistična organizacija (2021b). 


\subsection{Organizacijska struktura destinacije}

V organizacijskem smislu vodilno vlogo na destinaciji Podčetrtek predstavlja GIZ Podčetrtek, Bistrica ob Sotli in Kozje, ki razvija model skupnostnega managementa turistične destinacije, prav tako ima osnove za partnerski pristop $\mathrm{k}$ razvoju destinacijskega managementa (na sliki 5 je logotip destinacije in organizacije). Destinacija Podčetrtek predstavlja dober primer prakse, saj se na tem območju učinkovito povezujejo tri občine s svojimi deležniki znotraj destinacije. Velik poudarek je tudi na trajnostnem delovanju in razvoju.

\section{$\hat{1}$ \\ ( \\ VISIT PODČETRTEK BISTRICA OB SOTLI IN KOZJE}

Slika 5: Logotip destinacije Podčetrtek

Vir: Arhiv organizacije Turizem Podčetrtek, Bistrica ob Sotli in Kozje GIZ.

Destinacija sledi nacionalnim trendom razvoja turizma, kar dokazuje tudi pristop $\mathrm{k}$ Zeleni shemi slovenskega turizma v letu 2017, leto pozneje pa pristop k projektom z namenom digitalizacije marketinga destinacije in oblikovanju $5^{*}$ butičnih turističnih doživetij. Ker je sama organizacijska struktura destinacije primer dobre prakse, se lahko primerja $\mathrm{z}$ drugimi destinacijami $\mathrm{v}$ državi. $\mathrm{S}$ svojo strukturo ponazarja upravno-administrativni pristop k razvoju ter upravljanju. Destinacija je manj kompleksna, prav tako njena struktura upravljanja s turizmom, kar pa ne velja za uspešnost te gospodarske panoge.

\subsection{Ponudba na destinaciji}

Kot že rečeno, predstavlja turistična destinacija Podčetrtek kljub majhni površini pomembno območje v Sloveniji na področju turizma. Razvit je predvsem stacionarni turizem na osnovi termalne vode ter naravnih in kulturnih znamenitosti skupaj z drugimi elementi ponudbe, npr. vodni park Aqualuna, večnamenska športna dvorana, Minoritski samostan v Olimju ... (Turizem Podčetrtek, Bistrica ob Sotli in Kozje GIZ; b. d.). V povprečju destinacijo letno obišče približno 105.000 turistov, s čimer se uvršča med 10 najbolj obiskanih destinacij Slovenije. Natančneje, destinacija 
ustvari dobra $2 \%$ turističnih prihodov in slabe 3\% vseh turističnih nočitev v Sloveniji.

Ponudba destinacije je pestra, na voljo je kar nekaj antropoloških virov, tu prevladujejo zgodovinski objekti, običaji in dogodki. Najbolj poznani med njimi so na primer:

- Trg Podsreda - prvič omenjen leta 1377, na kar spominja še danes ohranjen sramotilni steber - pranger.

- Kukovičev mlin - danes je tu ekološka kmetija s kar 500-letno tradicijo mlina na kamen.

- Samostan Olimje - dvorec, poleg katerega stoji veličastna cerkev Marijinega vnebovzetja, $v$ pritličju južnega stolpa se skriva stara samostanska lekarna s freskami, zapuščina patrov Pavlincev, ki so 120 let bivali v olimskem samostanu.

- Grad Podsreda - na gradu je možen ogled grajskih prostorov, renesančne dvorane, stalne slikarske razstave Franceta Slane, stalne zbirke stekla iz nekdanjih glažut, grajske ječe in kuhinje ter grajske kleti.

- Jedrčev sejem - ponudba naravnih mil, domačih pekovskih in mesnih izdelkov, medenih izdelkov, trsnih cepljenk, sadik sadnega drevja, suhe robe, oblačil, obutve.

- Festival vina in čokolade - želja po združitvi dveh izjemnih produktov Slovenije je pripeljala do ideje in organizacije prvega vinsko-čokoladnega festivala v Sloveniji.

- Praznik kozjanskega jabolka - praznik kozjanskega jabolka je tradicionalna prireditev v Kozjanskem parku, ki se vsako leto odvije drugi teden v oktobru že vse od leta 2000.

$\mathrm{V}$ turistične namene v veliki meri vključujejo tudi naravne vire, ki so razporejeni po celotni destinaciji:

- Kozjanski regijski park - Kozjanski park je zavarovano območje, veliko $206 \mathrm{~km}^{2}$, s statusom regijskega parka. Značilna je prehodnost iz predalpskih hribovitih in pretežno z gozdovi poraščenih predelov v ravnino ob Sotli.

- Soteska in vodotok Bistrice ter Sotle - velja za najbolj ohranjeno in slikovito rečno sotesko v vzhodni Sloveniji. 
- Travniški sadovnjaki - sadjarstvo je tradicionalna panoga slovenskega kmetijstva, pomembno prisotna tudi na območju Kozjanskega parka.

- Rudnica - je hribovje nad Podčetrtkom ter Olimjem, kjer danes stoji razgledni stolp zdravja in veselja.

- Učne poti Vetrnik - Vetrnik je razgledni vrh na vzhodnem robu Bohorja v Kozjanskem parku. Nahaja se visoko nad dolino Bistrice.

- Gruska jama - leta 1988 je bila vključena v inventar najpomembnejše naravne dediščine, danes pa je pomembna naravna vrednota, ki meri 17,5 hektarja.

Med priljubljene točke obiska, ki se močno vključujejo v turizem destinacije in so zanj izrednega pomena, sodijo tudi:

- Terme Olimia,

- Dežela pravljic in domišljije,

- kolesarske poti,

- pohodniške poti,

- Jelenov Greben,

- Domačija Amon,

- vinske kleti,

- Hiša vin Emino,

- čebelarstva (Kozmus, Ilek),

- prehrambni obrati (Gostilna Šempeter, Haler),

- Čokoladnica Olimje.

\subsection{Vpliv turizma na destinacijo}

Turizem ima na destinacijo Podčetrtek pozitivne vplive. S spremljanjem kazalnikov povpraševanja in ponudbe tako na nacionalni kot destinacijski ravni pa se lahko pokažejo ekonomski učinki te panoge. Vstop v Zeleno shemo slovenskega turizma je vzpostavil sistem monitoringa, s katerim se nadzoruje vpliv turizma na okolje in družbo. Ključni indikatorji so zaenkrat še v nastajanju. 
Sicer pa lokalno prebivalstvo podpira turizem ter njegov razvoj. Glede na obiskanost destinacije ima turizem pozitivne učinke predvsem na gospodarstvo, saj ljudi spodbuja $\mathrm{k}$ razvoju podjetništva in same infrastrukture. Dokaz za to so investicijska dela, ki so bila izvedena $\mathrm{v}$ preteklih letih, kot so:

- izgradnja kolesarskih stez,

- ureditev lokalnih cest,

- posodobitev in postavitev informacijskih tabel,

- vzpostavitev sistema Trajnostno mobilno Obsotelje za izposojo koles,

- prenova večnamenske športne dvorane Podčetrtek. 
Poglavlje 4

\title{
Javni zavod Kozjanski park in festival »Praznik kozjanskega jabolka»
}

\author{
VALERIJA SLEMENŠEK
}

Kozjanski park je eno najstarejših in največjih zavarovanih območij v Sloveniji. Večji del Kozjanskega in Obsotelja je Republika Slovenija na osnovi kompromisa kulturnega izročila in naravovarstvenih vrednot leta 1981 razglasila za varovano območje - Spominski park Trebče (Zakon o Spominskem parku Trebče, Ul. SRS, št. 1/81).

Iz strokovnih, sistemskih in promocijskih razlogov se je območje vse bolj uveljavljalo kot Kozjanski park. Leta 1999 je Zakon o ohranjanju narave (Ul. RS št. 56/99) definiral ime, status in upravljavca zavarovanega območja, ki je postal regijski park z imenom Kozjanski park, katerega upravljavec je javni zavod. Regijski park je obsežno območje regijsko značilnih ekosistemov in krajine $z$ večjimi deli prvobitne narave, kjer je človekov vpliv večji, vendar z naravo trajnostno in sonaravno zgledno uravnotežen. 
Naravoslovne raziskave vedno znova izkazujejo izredno visoko stopnjo biotske pestrosti območja. Izredno visoka stopnja biotske pestrosti je bila podlaga za uvrstitev Kozjanskega parka med najpomembnejša naravovarstvena območja v Sloveniji in Evropi, saj se od leta 2004 večji del parka (69 \%) uvršča v ekološko pomembna območja Slovenije in evropsko pomembna posebna varstvena območja NATURA 2000 (ponazorjeno na sliki 6).

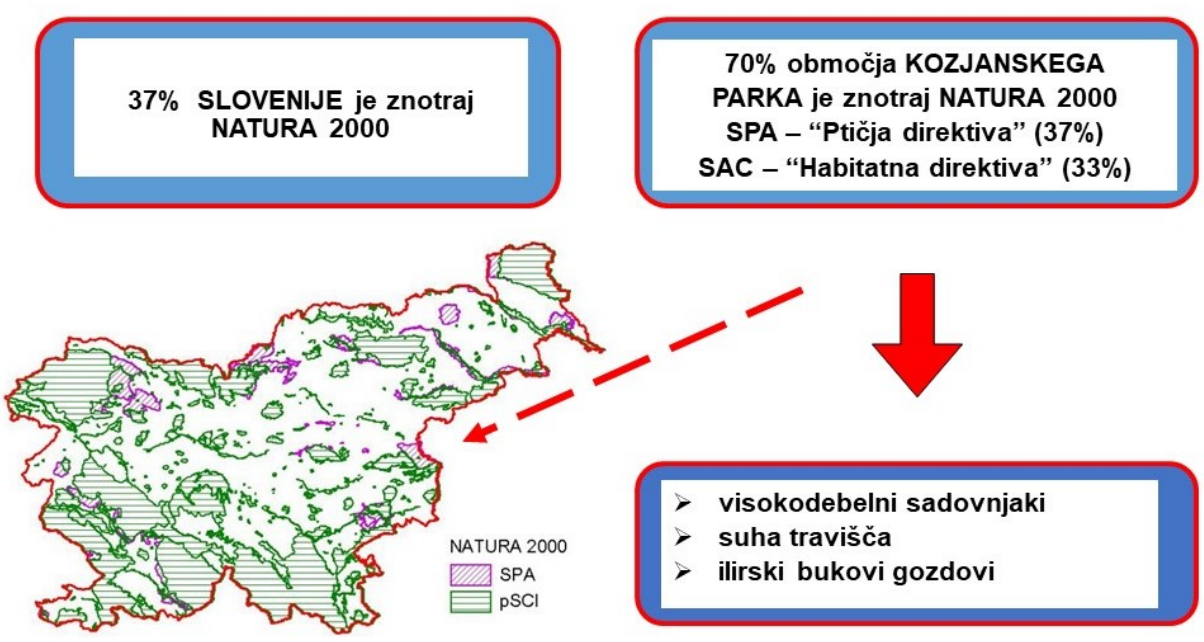

Slika 6: Zavarovana območja v Sloveniji

Vir: Javni zavod Kozjanski Park, 2012.

\subsection{Travniški sadovnjaki}

Travniški sadovnjaki imajo pomembno vlogo $\mathrm{v}$ kmetijskem in naravovarstvenem smislu. Nastajali so iz potrebe po zagotavljanju hrane za preživetje kmečkih ljudi. Sadili so jih na manjvrednih kmetijskih zemljiščih, strmejših legah, travnikih, pašnikih in v bližini domačij (slika 7). Pogosteje so se ohranili v hribovitem svetu, kjer so bili kmetje dalj časa povezani s tradicijo podeželja in odvisni od samooskrbe s hrano. Kmetje so cepili na sejance različne sorte, ki so jih izbirali glede na čas zrelosti in $z$ določenim namenom uporabe. $V$ preteklosti so travniški nasadi imeli pomembno gospodarsko vlogo, ker so $\mathrm{v}$ njih kmetje $\mathrm{z}$ ekstenzivno oskrbo sadnega drevja pridelali velike količine sadja, ki so ga prodali ali porabili predvsem za samooskrbo in predelavo $\mathrm{v}$ produkte, kot so suho sadje, sok, sadna vina, žganje in drugi sadni izdelki. 


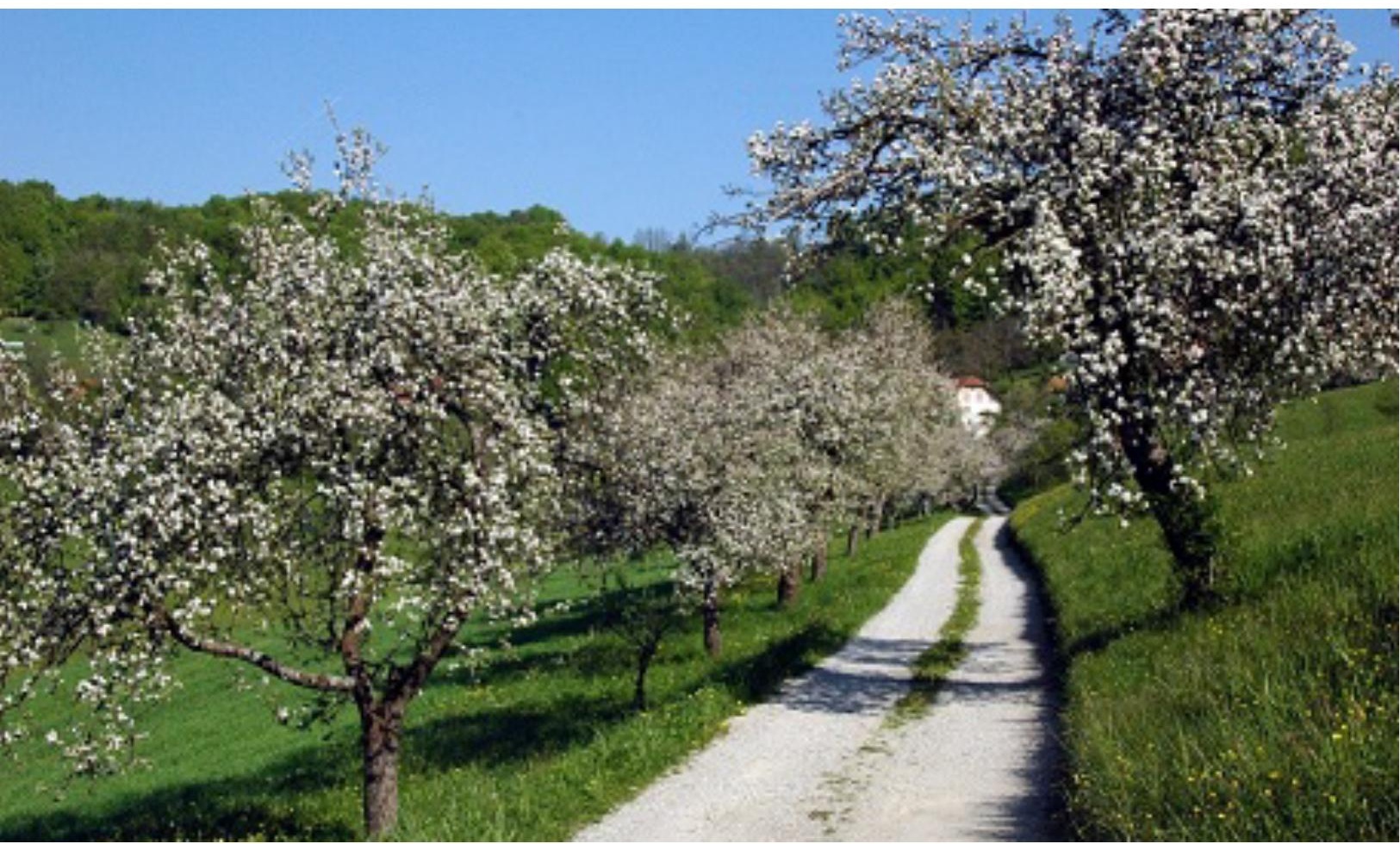

Slika 7: Cvetoči visokodebelni travniški sadovnjak

Vir: Arhiv Kozjanskega parka.

Z vidika ohranjanja narave predstavljajo travniški sadovnjaki dober primer naravi prijaznega ali sonaravnega kmetovanja. S svojo značilno podobo hkrati predstavljajo tudi pomembno estetsko kategorijo $\mathrm{v}$ prostoru in prispevajo $\mathrm{k}$ ohranjanju tipičnega videza pokrajine. Mnoge živali in rastline so neposredno povezane z omenjenim prostorom, zato z izginjanjem tega habitata izgubljajo svoj edini življenjski prostor. Visoka stopnja biodiverzitete je razlog za vključitev nekaterih območij med evropsko pomembna naravovarstvena območja Nature 2000, med katerimi so v Kozjanskem parku z znatnim deležem vključeni tudi travniški sadovnjaki.

Številne študije ter nacionalni in mednarodni projekti dokazujejo, da je ohranjanje habitatov travniških sadovnjakov v Kozjanskem parku izredno pomembno. Že od leta 1999 je bila s pristopom v projekt Oživljanje travniških sadovnjakov in sadnih vrtov v Sloveniji v veliki meri narejena osnova za nadgradnjo ostalih aktivnosti do današnjih dni (od oživitvenih rezi do Praznika kozjanskega jabolka). 
S projektom v okviru sosedskega programa Interreg IIIA (Slovenija-MadžarskaHrvaška) z naslovom Visokodebelni travniški sadovnjaki kot element ohranjanja biotske raznovrstnosti in estetske vrednosti krajine smo ob številnih aktivnostih pridobili dragocena kmetijska zemljišča za vzpostavitev kolekcijskega sadovnjaka in nove lokacije drevesnice. V sadovnjaku Kozjanskega parka imamo 117 različnih sort jabolk in 57 sort hrušk (sliki 8 in 9).

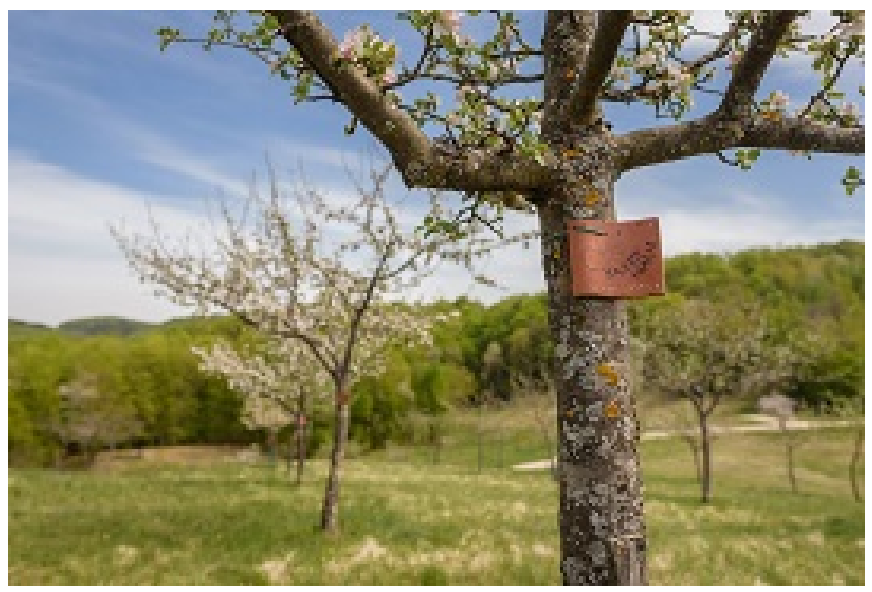

Slika 8: Sadovnjak Kozjanskega parka

Vir: Arhiv Kozjanskega parka.

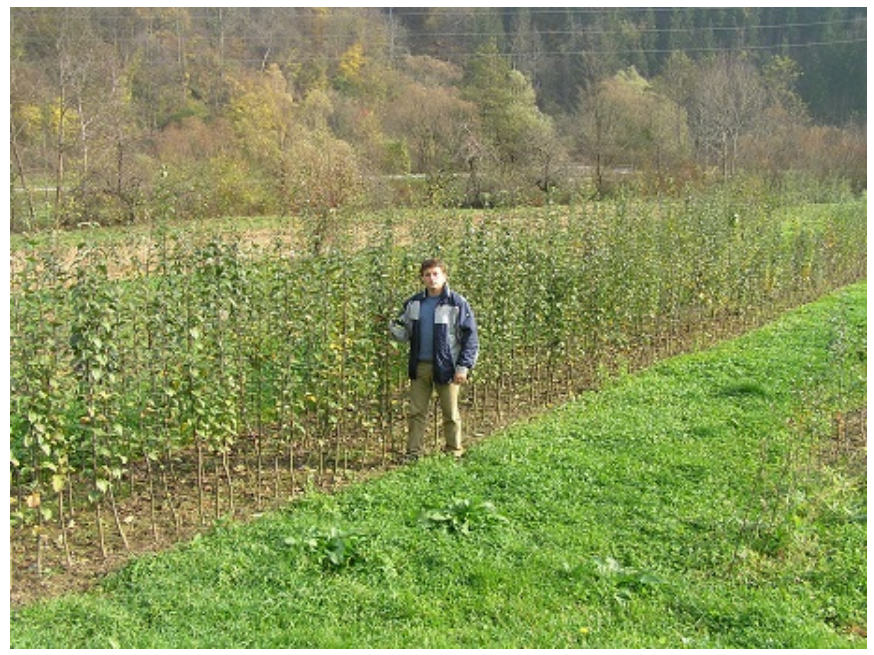

Slika 9: Drevesnica Kozjanskega parka

Vir: Arhiv Kozjanskega parka. 
V okviru projekta IPA (Čezmejno sodelovanje Slovenija-Hrvaška 2008-2013) z naslovom »Od vijeglavke do soka« smo pridobili strategijo dolgoročnega sonaravnega upravljanja s travniškimi sadovnjaki, sadjarski prestol in naziv Carjevič leta ter izboljšano tehnično opremljenost za vzdrževanje travniških sadovnjakov in predelovalnico sadja. $\mathrm{V}$ travniških sadovnjakih pridelano sadje se uvršča $\mathrm{v}$ kategorijo ekološko pridelane hrane, ki postaja $\mathrm{z}$ vsakim dnem zanimivejše tržno blago in nova priložnost za okoljsko ozaveščene pridelovalce. S predelovalnico sadja (slika 10) v jesenskem času pomagamo lastnikom, ki nimajo ustrezne opreme in tehnoloških znanj, predelati pridelano sadje $\mathrm{v}$ sadne sokove.

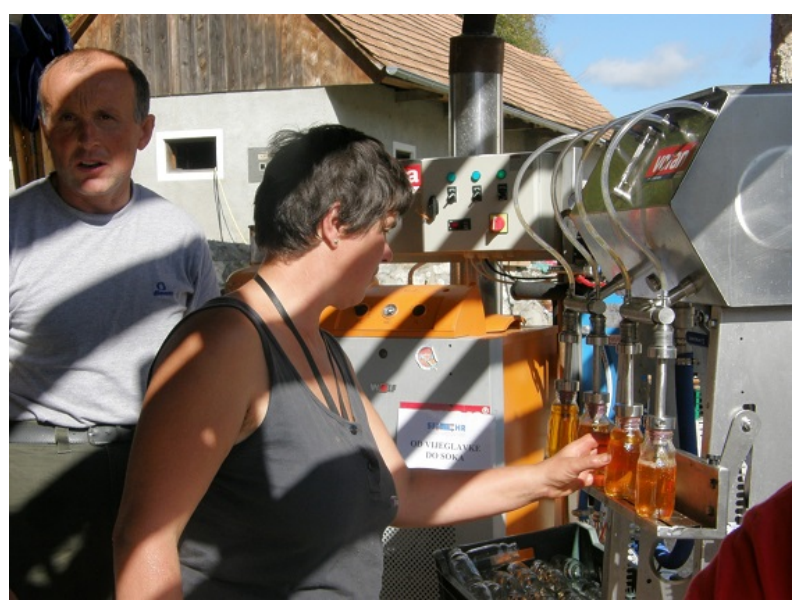

Slika 10: Predelovalnica sadja

Vir: Arhiv Kozjanskega parka.

S projektom »Priložnosti v posavskih tradicionalnih sadovnjakih« (Leader) smo vzpostavili učna mesta in izvedli izobraževanja za sadjarske mojstre, permakulturne načrtovalce in predelovalce sadja (sliki 11 in 12). Rezultati projektov so številni novi in obnovljeni travniški sadovnjaki ter lastniki, ozaveščeni o pomenu tovrstnih nasadov za območje Nature 2000 in celotno zavarovano območje Kozjanskega parka. 


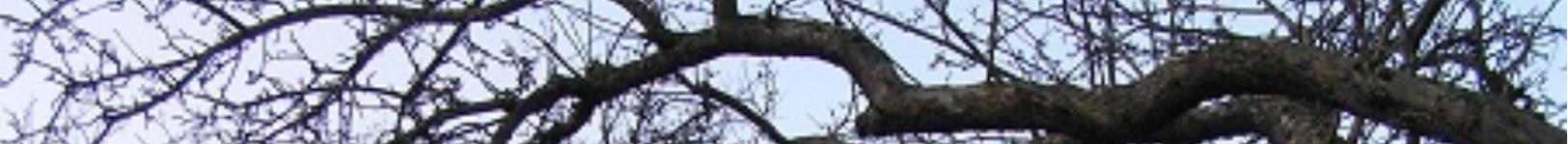
120 (2)

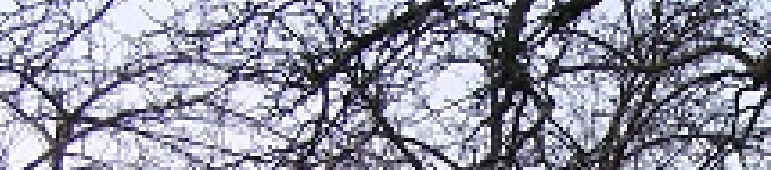

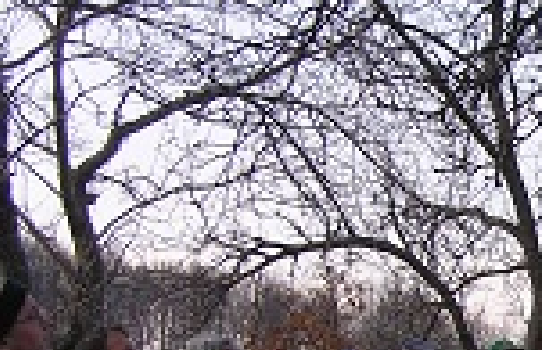
$x+40 x^{6} x^{2}$
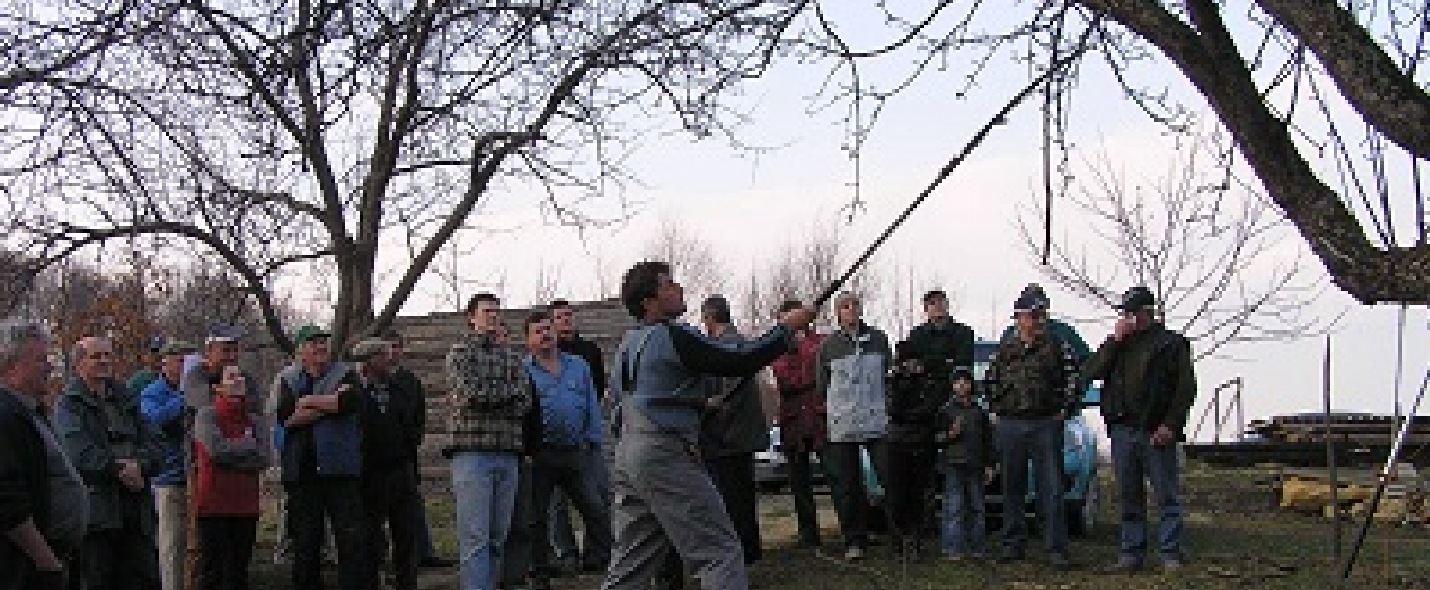

th 4 t. 2.

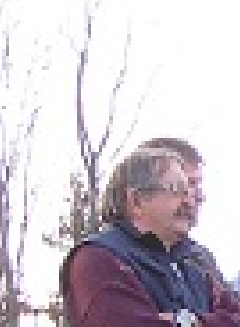

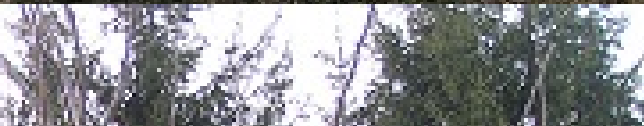
(i) 8 ;

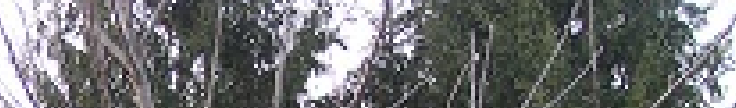

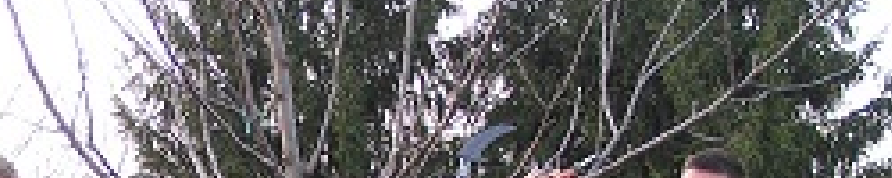
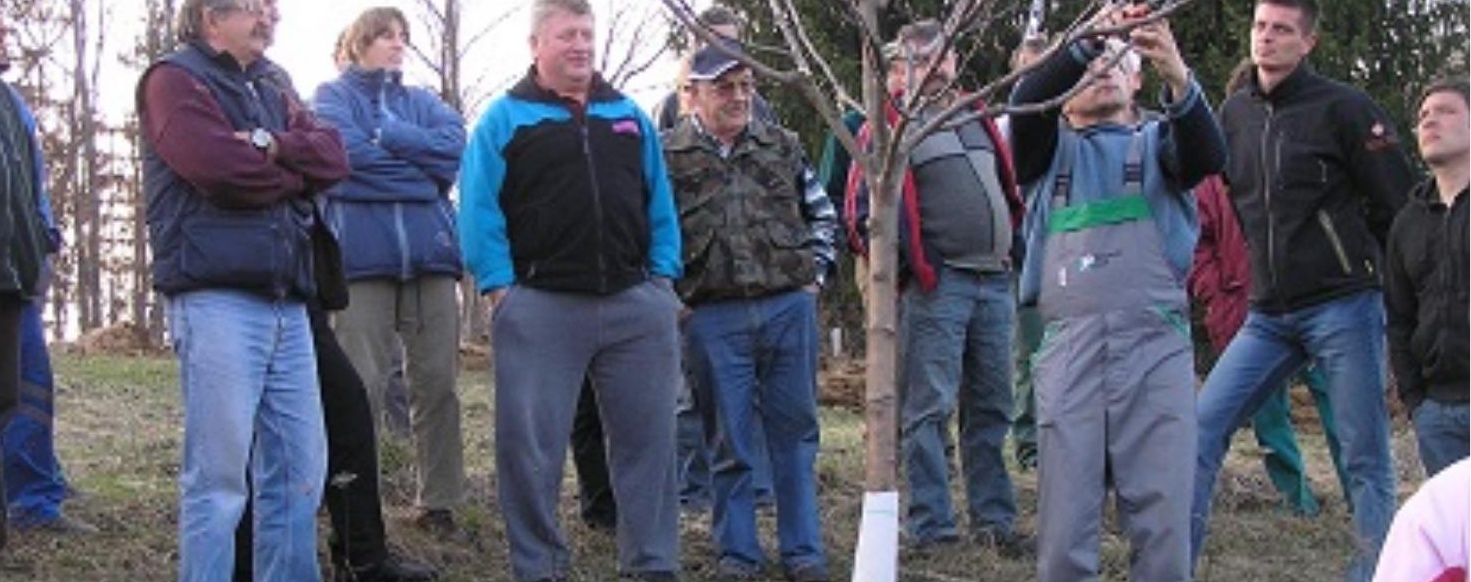


\subsection{Praznik kozjanskega jabolka}

Kozjanska jabolka rastejo v visokodebelnih travniških sadovnjakih, ki so med naravovarstveno najpomembnejšimi habitati v Kozjanskem parku - tu namreč živijo nekatere vrste ogroženih ptic, kot so vijeglavka, zelena žolna, pivka, veliki skovik, pogorelček, čuk in rjavi srakoper in ravno zaradi njih so travniški sadovnjaki vključeni v območje Natura 2000 po »Ptičji direktivi«.

Ohranjanje travniških sadovnjakov se nam je zdelo tako pomembno, da smo iskali način, kako širši javnosti predstaviti nujnost ohranjanja tega habitata. Odločili smo se, da organiziramo prireditev, na kateri bomo prestavili naše strokovno delo, hkrati pa omogočiti domačinom, da se predstavijo s svojimi produkti. Prireditev je iz skromnih začetkov prerasla $\mathrm{v}$ eno največjih in najodmevnejših tovrstnih prireditev $\mathrm{v}$ Sloveniji, pa tudi širše.

V prvih letih so se ponudniki predstavljali nekje na 7-10 stojnicah. Temu primerno je bilo tudi število obiskovalcev - skromno. Na desetem prazniku smo presegli magično število 100 ponudnikov. Število ponudnikov je iz leta v leto naraščalo in leta 2015 smo dosegli število 150 stojnic, kar pa je seveda največ, kar trg Podsreda prenese. Prireditev od takrat obišče okoli 20.000 obiskovalcev (slika 13).

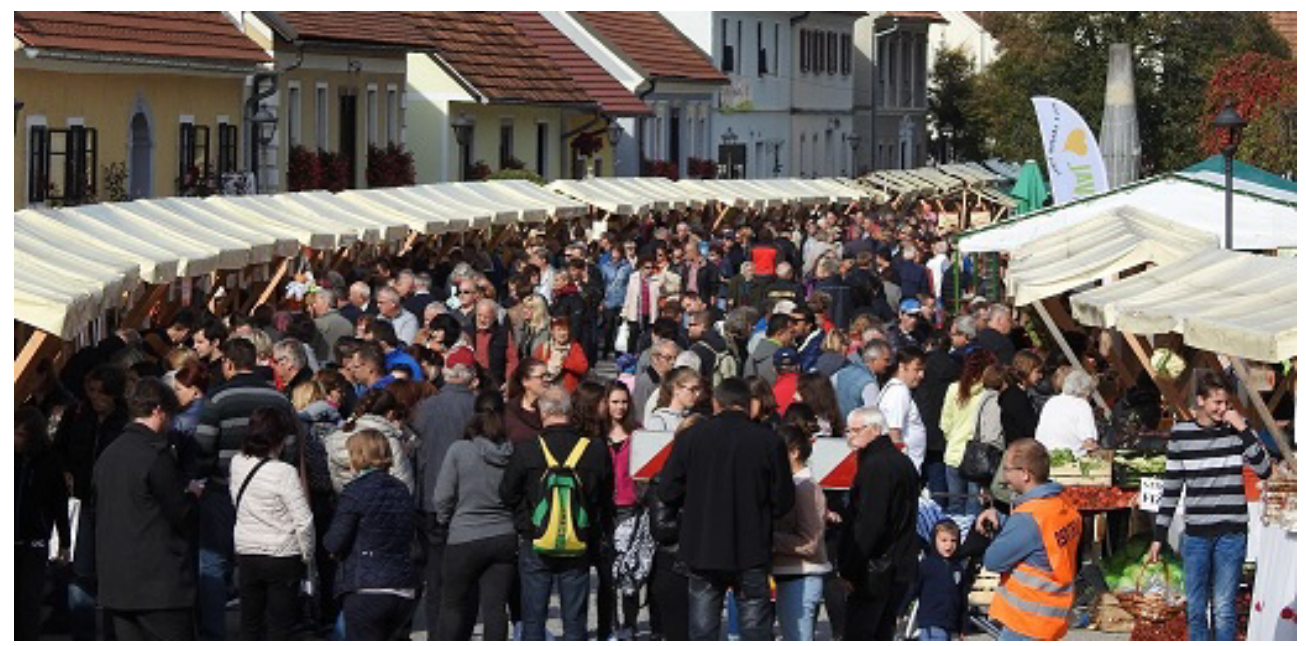

Slika 13: Osrednje prizorišče Praznika kozjanskega jabolka

Vir: Arhiv Kozjanskega parka.

Slika 11: Prikaz oživitvene rezi, Vir: Arhiv Kozjanskega parka. (levo odzgoraj)

Slika 12: Prikaz vzgojne rezi, Vir: Arhiv Kozjanskega parka. (levo odspodaj) 
$\mathrm{V}$ vseh teh letih je prireditev ostala zvesta svojemu poslanstvu ter se razvila v osrednjo in zelo odmevno okoljsko, etnološko in naravovarstveno prireditev domačinov brez "globalnega« kiča in krame. Postala je tudi eden od največjih naravovarstvenih in okoljskih dogodkov v državi. Prireditev je vsebinsko vpeta $\mathrm{v}$ sodobna prizadevanja za trajnostni, krožni in sonaravni razvoj, ob upoštevanju načel varstva narave. Praznik kozjanskega jabolka pomembno vpliva na prepoznavnost Kozjanskega, sejemsko dogajanje pa opisujejo kot »okoljski sejem z dušo«. Odlična parkovna praksa nege visokodebelnih travniških sadovnjakov rezultira $\mathrm{v}$ zdravem jabolku, ki je »več kot zgolj sadež«, ohranjeni krajini, naravi in sonaravnem trajnostnem razvoju.

\subsection{Kaj se dogaja v času Praznika kozjanskega jabolka?}

Praznik kozjanskega jabolka poteka vedno drugi teden v oktobru. Sejemski del Praznika kozjanskega jabolka dopolnjujejo številni dogodki, ki jih organiziramo skupaj z lokalnimi društvi:

- Pohod po kozjanskih sadovnjakih, ki je uvod v praznik in ga organiziramo skupaj s Planinskim društvom Podčetrtek (slika 14).

- Aškerčev večer, ki ga organiziramo skupaj s kulturnim društvom Podsreda.

- Športno društvo Podsreda organizira rekreacijski tek na grad Podsreda »S kozjanskim jabolkom v Podsredi do bolj zdravega življenja«.

- Kolesarska sekcija Orans iz Bistrice ob Sotli organizira kolesarjenje »Z jabko na kolo«.

- Gobarsko društvo Kozjansko-Kozje pripravi razstavo gob.

V organiziranju prireditve nismo več sami, kar nam je seveda dodatna spodbuda in motivacija, saj vidimo, da je kraj prireditev vzel za svojo.

Slika 14: Pohod po kozjanskih sadovnjakih, Vir: Arhiv Kozjanskega parka. (desno odzgoraj)

Slika 15: Prva postavitev razstave Stare sorte jabolk, Vir: Arhiv Kozjanskega parka. (desno odspodaj) 
Razstava starih sort jabolk je v programu Kozjanskega jabolka tradicionalna. V bistvu gre vsako leto za enako razstavo, vendar vedno v drugi preobleki. Na sliki 15 je prikazana prva postavitev razstave »Stare sorte jabolk«, ki smo jo ponovili ob 10. in 20. obletnici praznovanja. Razstavo začnemo pripravljati že v poletnih mesecih ob zorenju ranih sort jabolk, ki jih do razstave shranjujemo $\mathrm{v}$ hladilnici. Tradicionalno razstavo starih sort jabolk vsako leto spremlja tudi razstava, pripravljena skupaj s partnerji, pa naj bodo to društva, zavodi ali pa posamezniki.

Drugi vikend v oktobru je v Podsredi namenjen sejemskemu dogajanju, ki ga spremlja bogat kulturni program. Na stojnicah se predstavljajo številni ponudniki ekoloških in drugih kmetij, tradicionalni obrtniki, šole z območja Kozjanskega parka, partnerske institucije ... V kulturnem programu se zvrsti več kot 200 nastopajočih - od ljudskih pevcev in godcev, tamburašev, plesnih skupin, mažoretk do citrarjev in harmonikarjev. V kulturnem programu vsako leto sodelujejo naši partnerji iz tujine.

Osrednjo vlogo na stojnicah imajo ekološke kmetije iz zavarovanega in biosfernega območja ter umetniško-obrtniške delavnice. Poudarek je na starih sortah jabolk, zdravih kmetijskih pridelkih, pridelanih na sonaravni način, ter izvirno in domiselno predelanem sadju v ozimnico. Obrtniške delavnice ponujajo vrhunske izdelke ljudske tradicionalne obrti. Na prireditvi se predstavljajo tudi društva in strokovne službe, ki soupravljajo s prostorom zavarovanega območja, ter množica glasbenih skupin, ki s kulturnim programom prispevajo k prijetnemu vzdušju na prireditvi.

Za pestrejše dogajanje na sami prireditvi so pripravljeni tudi tekmovalno-zabavni program in otroške delavnice. Tekmovalno-zabavni program je seveda v prvi vrsti posvečen jabolku. Tako vsi zainteresirani rešujejo uganke na temo jabolk, poslušajo oglašanje ptic, ki živijo v travniških sadovnjakih, in ugotavljajo, za katero ptico gre, največ zanimanja pa je za tekmovalno igro najdaljši olupek (slika 16). Med tekmovalci je večkratni zmagovalec Martin Magdalenc. Martin je v letu 2018 nalupil rekordno dolg olupek, ki je meril kar $730 \mathrm{~cm}$ (slika 17).

Slika 16: Tekmovanje v najdaljšem olupku; Vir: Arhiv Kozjanskega parka. (desno odzgoraj)

Slika 17: Martin Magdalenc in njegov zmagovalni olupek; Vir: Arhiv Kozjanskega parka. (desno odspodaj) 

Prav zaradi nujnosti ohranitve travniških sadovnjakov smo v letu 2009 prvič podelili naziv Carjevič. Ta laskavi naziv prejme lastnik sadovnjaka, ki po oceni komisije v tekočem letu najlepše poskrbi za svoj travniški sadovnjak. Sadjarski tron (prikazan na sliki 18), ki stoji pred upravo Kozjanskega parka, je izdelal domačin, vsestranski umetnik, Franci Černelč.

Tudi »štrudlmojstrci« sta bili prvič izbrani v letu 2009. Ker je bilo tekmovanje v peki »štrudla« (na sliki 19) lepo sprejeto tako med tekmovalci kot tudi med tistimi, ki smo jabolčni »štrudl« samo jedli, je tudi to tekmovanje postalo tradicionalno.

Bistvo prireditve Praznik kozjanskega jabolka je promocija in trženje produktov iz zavarovanega območja, ki se pridelujejo in predelujejo na ekološki in zdravju čimbolj prijazen način. S promocijo konkretnih produktov želimo osveščati in izobraževati prebivalce in obiskovalce o naravovarstvenem in ekološkem pomenu sadovnjakov ter o vrstah, ki v njih uspevajo. Širši pomen prireditve je v promoviranju jabolka, jablane, travniškega sadovnjaka $\mathrm{z}$ namenom njegove ohranitve, revitalizacije ali obnove. Urejeni in ohranjeni travniški sadovnjaki bodo pomenili prepoznavnost cilja, vizijo razvoja ter skrb za ohranjanje narave in varovanje okolja ter ustvarjanje novih tržno-promocijskih priložnosti.

Jabolko iz visokodebelnega travniškega sadovnjaka $\mathrm{v}$ simbolnem pomenu predstavlja varovanje narave, nadaljevanje tradicije in dediščine naših prednikov, blagostanje in zdravo hrano ter simbol prepoznavnosti zavarovanega območja Kozjanskega parka in identifikacijo domačinov z zavarovanim območjem. Jabolko tako povezuje upravljavca zavarovanega območja, domačine, naravo in kulturo. Jabolko, ki smo ga na simbolni in stvarni ravni postavili v središče prazničnega programa (slika 20), vsako leto privabi številne strokovnjake, razstavljavce in prodajalce, pa tudi številne kulturne skupine in umetnike iz domovine in tujine.

Slika 18: Carjevič leta 2019 - Franc Lupšina na sadjarskem tronu; Vir: Arhiv Kozjanskega parka. (desno odzgoraj) Slika 19: Štrudlmojstra leta 2014; Vir: Arhiv Kozjanskega parka. (desno odspodaj)

Slika 20: Jabolko krasi krožišče v Kozjem; Fotografija: Mojca Valenčak. (na strani 50) 


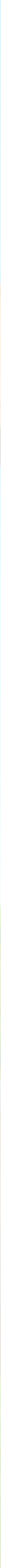


Poglavlje 5

\title{
Analiza destinacije in akcijski načrt
}

\author{
LuKas Deu, Simon DORFFner, IMELdA FELIĆ, LARA Fudurić, \\ JoŠKo Glavina, LUKa GoŠEK, TENA Gregorić, SARA HORVAT, \\ iva Jerotijević, Patricija Kelhar, Franjo Krapec, Katja Magdič, \\ Nikola Mahnić, Petar Milošević, Eva Pašalić, Janko Pelikan, \\ MARIJA PRISTAŠ IN LOVRO VITKO
}

$\mathrm{V}$ sklopu sekundarne in primarne raziskave je bila oblikovana analiza SWOT destinacije Podčetrtek, Bistrica ob Sotli in Kozje. Skupine so oblikovale vizijo destinacije, kulturnega turizma in prireditve Praznik kozjanskega jabolka. Sledijo cilji in akcijski načrti z ukrepi na področju kulturnega turizma.

\subsection{Analiza SWOT}

Pred izdelavo strategij in smernic je treba narediti temeljito analizo trenutnega stanja turizma na destinaciji, ki jo lahko učinkovito predstavimo s pomočjo analize SWOT. $\mathrm{Z}$ njo interpretiramo notranje in zunanje okolje ter subjekte, ki jih preučujemo. Pomembni elementi analize SWOT, s katero predstavimo stanje, so prednosti, slabosti, priložnosti in grožnje. V spodnji tabeli 1 prikazujemo analizo SWOT, ki smo jo naredili za destinacijo Podčetrtek, Bistrica ob Sotli in Kozje. 
Tabela 1: Analiza SWOT destinacije Podčetrtek, Bistrica ob Sotli in Kozje.

\begin{tabular}{|c|c|}
\hline PREDNOSTI & TI \\
\hline 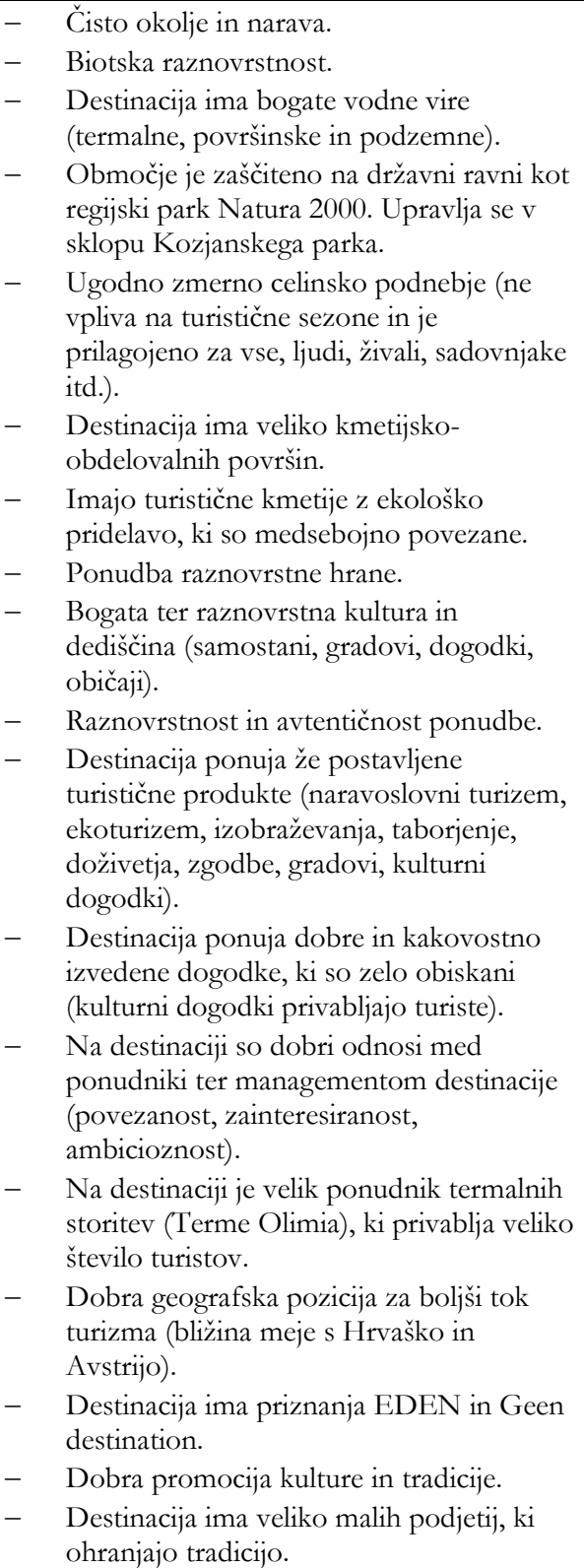 & $\begin{array}{ll}\text { - } & \text { Nezadostna izkoriščenost naravnih in } \\
\text { kulturnih elementov. } \\
\text { - }\end{array}$ \\
\hline
\end{tabular}




\begin{tabular}{|c|c|}
\hline PRILOŽNOSTI & SROŽ \\
\hline $\begin{array}{l}\text { - Trend mehke mobilnosti (za prihod na } \\
\text { prireditev in za logistiko prireditve) ter } \\
\text { večja dostopnost za nakup tovrstne } \\
\text { mobilnosti. } \\
\text { - } \\
\text { Geotermalna voda kot zeleni vir energije } \\
\text { in turizma. } \\
\text { - Turisti iščejo raznovrstno ponudbo, ki je } \\
\text { tudi personalizirana (eko in domačnost). } \\
\text { - Trend razvoja športnega turizma (veliko } \\
\text { profesionalnih športnih ekip išče prostor } \\
\text { za treninge). } \\
\text { - Inovativnost (na primer pri prikazu } \\
\text { dediščine). } \\
\text { - Razvoj butičnega turizma v naravi. } \\
\text { - Večje zanimanje skupin turistov za } \\
\text { opazovanje ptic in živali. } \\
\text { - Trend zanimanja za kulturni turizem } \\
\text { (dediščina, gradovi, Kozjansko jabolko). } \\
\text { Dogodki so priložnost za promocijo } \\
\text { lokalnih ponudnikov in kulturnih storitev. } \\
\text { Razmah tehnologije za spletne prireditve } \\
\text { in povpraševanje po teh storitvah. } \\
\text { Digitalna promocija in marketing - novi } \\
\text { kanali, ki so popularni (atraktivne slike in } \\
\text { videi). } \\
\text { Velik pomen varnosti. } \\
\text { - Možnosti za prihod turistov iz drugih } \\
\text { geografskih lokacij. } \\
\text { Bližina letališča (Ljubljana, Zagreb) za } \\
\text { boljšo dostopnost turistov. } \\
\text { Priložnost za investicije tujih investitorjev } \\
\text { ali projektno EU sofinanciranje zelenih } \\
\text { rešitev. }\end{array}$ & 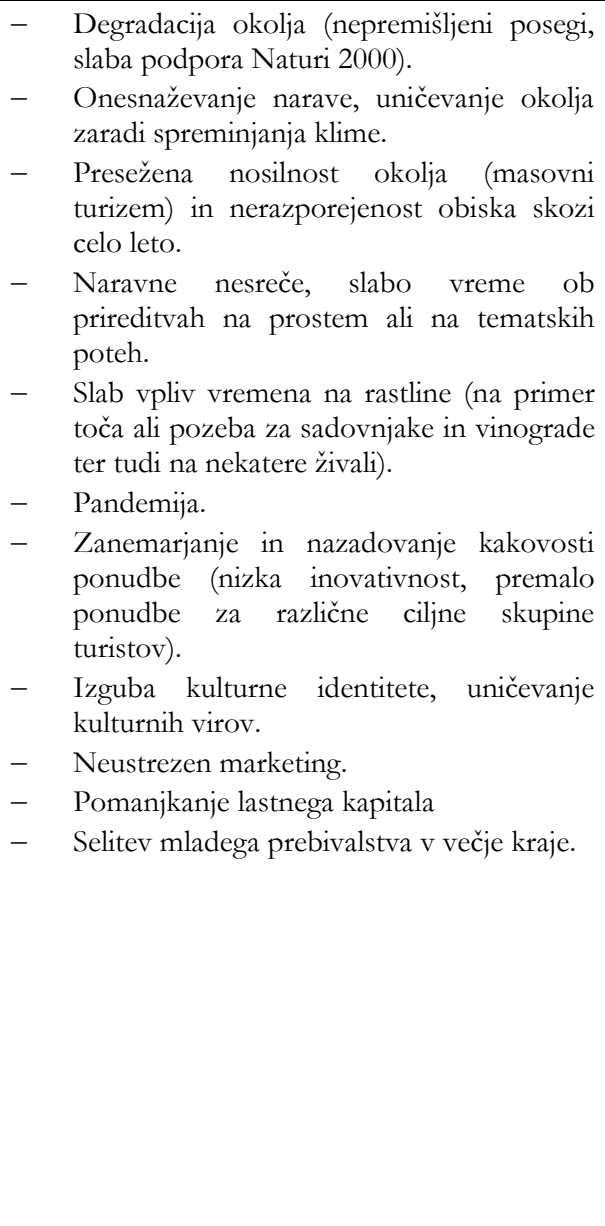 \\
\hline
\end{tabular}

\subsection{Vizija destinacije in kulturnega turizma}

$\mathrm{V}$ tem poglavju podajamo podroben opis predlogov vizije kulturnega turizma $\mathrm{v}$ destinaciji Podčetrtek kot tudi opis vizije destinacije Podčetrtek, Bistrica ob Sotli in Kozje. Vizija predstavlja sliko idealne prihodnosti podjetja, organizacije ali družbe ter jasno podobo prihodnjih dogodkov. $\mathrm{V}$ nadaljevanju smo na podlagi teh predlogov vizije postavili več ciljev. 
- Predlog vizije destinacije

Vizija destinacije Podčetrtek, Bistrica ob Sotli in Kozje je, da bo do leta 2030 ponujala trajnostni turizem za vsakogar. $S$ trajnostnim turizmom mislimo razvoj in vzdrževanje destinacije na tak način, da bo dolgoročno uspešno poslovala ter pri tem ne bo ogrozila naravnega in družbenega okolja. Turizem za vsakogar pa bo vključeval vse starostne in interesne skupine turistov, ne glede na njihove oviranosti ali želje.

Za uresničitev te vizije je treba uresničiti določene kriterije. Najprej je treba ustvariti trajnostne turistične produkte, kot so dogodki, ogledi in vodenja ter nastanitve, ki so prilagojeni različnim ciljnim skupinam turistov. Nato moramo poskrbeti za lahko dostopne informacije tako za turiste kot za domačine. Marketinška strategija se mora bolj osredotočiti na trajnost in poskrbeti, da komuniciranje o trajnosti ne bo enkratni dogodek, ampak bo vpeto v vsakdan prebivalcev destinacije. Tako bi na primer lahko bili vpeti že otroci v vrtcih in šolah, kjer bi med vzgojo o trajnosti likovno ustvarjali in izvajali projekte. Lokalna gastronomija naj se še bolj vključi v turistično ponudbo destinacije, tako da bodo povezani pridelovalci in gostinci. Nenazadnje pa naj destinacija poskrbi tudi za regulacijo cene, ki bo primerna tako za ponudnike kot turiste.

- Prvi predlog vizije destinacije in kulturnega turizma

Vizija destinacije Podčetrtek, Bistrica ob Sotli in Kozje je, da bo destinacija do leta 2030 privabila raznolike turiste, ki bodo iskali ponudbo destinacije, usmerjeno v naravno in kulturno dediščino. $\mathrm{Na}$ destinaciji bomo ponujali kakovostne, profesionalne, tradicionalne in lokalne izdelke ter storitve, prilagojene za vsako ciljno skupino turistov.

Vizija kulturnega turizma v Podčetrtku, Bistrica ob Sotli in Kozje je, da bo destinacija do leta 2030 ponudila različne dobrine, ki temeljijo na snovni in nesnovni kulturni dediščini. Ponudba bo prepoznavna tudi na svetovni ravni, razvoj kulturne dediščine pa bo temeljil na smernicah trajnostnega turizma. 
- Drugi predlog vizije destinacije in kulturnega turizma

Destinacija Podčetrtek, Bistrica ob Sotli in Kozje temelji na avtentičnosti ter ohranjanju kulturne in naravne dediščne. $S$ tem bo drugačna od drugih destinacij in bo dokazovala trajnostni razvoj, ki močno vpliva na ugled turizma na destinaciji. S svojim delovanjem bo pozitivno vplivala tudi na ugled Slovenije kot celote in tako krepila avtentičnost, kakovost, dostopnost in vidnost slovenskega turizma zunaj države.

Destinacija Podčetrtek, Bistrica ob Sotli in Kozje večinoma ponuja izdelke kulturne dediščine. Kulturna dediščina same destinacije je raznolika in polna muzejev, majhnih gradov, cerkva in samostanov, na teh lokacijah pa pogosto organizirajo prireditve, festivale in različne izlete. Vizija kulturnega turizma te destinacije je, da bo zaradi kulturnega turizma več turistov in obiskovalcev obiskalo destinacijo zunaj sezone, njihov glavni motiv obiska pa bodo kulturne vsebine (ne samo kot stranski učinek potovanja $z$ drugim motivom). Verjamemo, da bo s tem pristopom prišlo do rasti števila nastanitvenih kapacitet in zadovoljstva ter večjega zanimanja turistov za destinacijo.

- Tretji predlog vizije destinacije in kulturnega turizma

Gostom bomo na destinaciji Podčetrtek, Bistrica ob Sotli in Kozje ponujali avtentična in trajnostna doživetja. Ohranjali in razvijali bomo privlačnost destinacije $\mathrm{z}$ vključevanjem nove ponudbe, skladne s sodobnimi trendi, ter $\mathrm{s}$ tem prispevali $\mathrm{k}$ pozitivnemu okolju in trajnostnemu razvoju turizma.

Vizija kulturnega turizma na destinaciji Podčetrtek, Bistrica ob Sotli in Kozje je, da bomo sledili novim trendom v kulturnem turizmu. Povezovali bomo sodobno in tradicionalno dediščino v obliki avtentičnih kulturnih doživetij, ki bodo dostopna za vse. 
- Prvi predlog vizije prireditve »Praznik kozjanskega jabolka«

Praznik kozjanskega jabolka temelji na trajnostnem razvoju in ohranjanju kulturne dediščine ter predstavlja širšemu svetu zanimiv turistični produkt. Kot ena bolj pomembnih prireditev v Sloveniji bi lahko imela še večji vpliv na ozaveščanje o varovanju narave. Naša vizija je, da bo ime prireditve Praznik kozjanskega jabolka znano v svetu, da bo prireditev temeljila na ohranjanju domače kulture in narave ter da bodo njene vsebine, ki so vezane na jabolka, del turističnih produktov, ki bodo vabili goste od blizu in daleč, da jih poskusijo. Del vizije je tudi dostopnost, saj bo v prihodnosti festival postal dostopen vsem vrstam turistov.

- Drugi predlog vizije prireditve »Praznik kozjanskega jabolka«

Vizija prireditve Praznik kozjanskega jabolka je, da bo festival v naslednjih letih postal mednarodno bolj prepoznaven s kakovostno promocijo. Ponašal se bo z več raznolikimi dogodki na raznih lokacijah destinacije.

\subsection{Cilji in akcijski načrt kulturnega turizma}

V nadaljevanju so podrobneje opisani cilji, sledijo tabele $\mathrm{z}$ akcijskimi načrti za uresničitev ciljev.

\section{Cilj 1: Novi paketi doživetij na področju kulturnega turizma}

Želimo ustvariti paketno ponudbo, ki bo skupek več aktivnosti (prevoz, delavnice, vstopnine, degustacija, hrana, nastanitev) in bo cenejša kot rezervacija posameznih produktov. Vsak paket doživetij bo namenjen določeni ciljni skupini, zanje pa bomo pripravili tudi ustrezno promocijo. Akcijski načrt je predstavljen v tabeli 2. 


\section{Tabela 2: Ukrepi za cilj 1}

\begin{tabular}{|c|c|c|c|c|c|}
\hline$\frac{2}{2}$ & 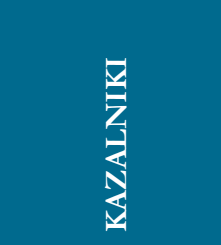 & 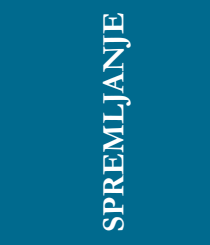 & 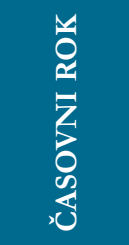 & 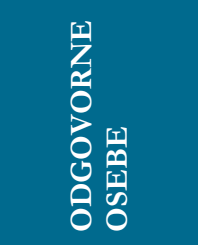 & 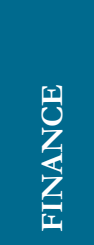 \\
\hline $\begin{array}{l}\text { 1. Oblikovanje } \\
\text { in izdelava } \\
\text { vodnika za } \\
\text { območje s } \\
\text { poudarkom na } \\
\text { kulturnem } \\
\text { turizmu }\end{array}$ & $\begin{array}{l}\text { Število prodanih } \\
\text { vodnikov }\end{array}$ & $\begin{array}{l}\text { Vodenje } \\
\text { evidence števila } \\
\text { izdanih in } \\
\text { prodanih } \\
\text { vodnikov }\end{array}$ & $\begin{array}{l}\text { Do } \\
\text { začetka } \\
\text { septemb } \\
\text { ra } 2021\end{array}$ & $\begin{array}{l}\text { Turizem } \\
\text { Podčetrtek, } \\
\text { Bistrica ob } \\
\text { Sotli in Kozje } \\
\text { v sodelovanju } \\
\text { z občinami }\end{array}$ & $6377 €$ \\
\hline $\begin{array}{l}\text { 2. Posneti } \\
\text { promocijski } \\
\text { videi za } \\
\text { vsakega od } \\
\text { paketov }\end{array}$ & $\begin{array}{l}\text { Število } \\
\text { dokončanih } \\
\text { produktov/pro } \\
\text { mocij-skih } \\
\text { videov }\end{array}$ & $\begin{array}{l}\text { Interakcija na } \\
\text { družabnih } \\
\text { omrežjih, ko so } \\
\text { filmi objavljeni }\end{array}$ & $\begin{array}{l}\text { Do } \\
\text { začetka } \\
\text { oktobra } \\
2021\end{array}$ & $\begin{array}{l}\text { Turizem } \\
\text { Podčetrtek, } \\
\text { Bistrica ob } \\
\text { Sotli in Kozje }\end{array}$ & $1414 €$ \\
\hline $\begin{array}{l}\text { 3. Povezava } \\
\text { lokalnih } \\
\text { ponudnikov v } \\
\text { pakete }\end{array}$ & $\begin{array}{l}\text { Število } \\
\text { ponudnikov, } \\
\text { pripravljenih za } \\
\text { sodelovanje pri } \\
\text { ustvarjanju } \\
\text { paketov }\end{array}$ & $\begin{array}{l}\text { Vodenje } \\
\text { evidence } \\
\text { ponudnikov }\end{array}$ & $\begin{array}{l}\text { Do } \\
\text { začetka } \\
\text { oktobra } \\
2021\end{array}$ & $\begin{array}{l}\text { Turizem } \\
\text { Podčetrtek, } \\
\text { Bistrica ob } \\
\text { Sotli in Kozje }\end{array}$ & $500 €$ \\
\hline $\begin{array}{l}\text { 4. Digitalna } \\
\text { kulturna } \\
\text { ponudba za } \\
\text { otroke }\end{array}$ & $\begin{array}{l}\text { Število } \\
\text { udeleženih otrok }\end{array}$ & $\begin{array}{l}\text { Seznam } \\
\text { udeleženih }\end{array}$ & $\begin{array}{l}\text { V letu } \\
2022\end{array}$ & $\begin{array}{l}\text { Lokalne šole, } \\
\text { FT UM, } \\
\text { Kozjanski park }\end{array}$ & $2000 €$ \\
\hline
\end{tabular}

UKREP 1: Predlagamo, da se izdela vodnik po destinaciji s poudarkom na kulturnem turizmu, v katerem se predstavijo vse kulturne znamenitosti in dogodki, ki se odvijajo, predstavljali pa bi tudi nove pakete kulturnega turizma, ki jih ponujajo na destinaciji. V ceno je všteta izdelava 2 x 500 vodnikov (500 slovenskih in 500 angleških - 2376,56 €) velikosti A6 (Demago, 2020), grafično oblikovanje in sestava vodnika $(3000 €)$ ter fotografiranje znamenitosti in dogodkov (približno 100 slik $1000 €)$. Vodnik bi ponujali na stojnicah in $\mathrm{v}$ turističnem centru, izdajo pa predlagamo na Prazniku kozjanskega jabolka 2021. Vodnik bi potem prodajali po ceni $10 €$. 
UKREP 2: Predlagamo, da se za vsakega od paketov posname kratek promocijski video, ki bo potencialnim obiskovalcem predstavljal, kaj lahko pričakujejo, če izberejo ta paket, hkrati pa bodo namenjeni kot promocija same destinacije. V financah je zajet strošek snemanja, kar zajema 2 snemalna dneva (vsak dan 8 ur s snemalcem in kamero $-854 €$ ) in video montaža vseh posnetkov ( $4 \mathrm{~h}$ na video $560 €$ ), da ustvarijo štiri od 2- do 3-minutne videoposnetke (SLAK d.o.o., b. d.). Predlagamo, da se za nastopajoče izbere družine ponudnikov oziroma se lahko izbere sodelujoče v okviru nagradne igre na Instagramu (prostovoljni statisti).

UKREP 3: Predlagamo, da se na novo ustvarijo paketi, vsak namenjen določeni ciljni skupini. $\mathrm{V}$ paketih bi združili različne lokalne ponudnike, ki bi bili zanimivi tej skupini, in sicer:

- Družinsko doživetje: Dan bi začeli v muzeju kmečke opreme, kjer bi izvedli delavnico pletenja košare. Po tej delavnici bi se odpravili na kosilo $\mathrm{k}$ domačiji Haler, po kosilu pa bi se odpravili v Olimsko žajfco, kjer bi izdelali svoje naravno milo. Nato bi se odpravili do Olimja in si ogledali samostan in čokoladnico. Posladkali bi se z že v ceno vključenimi čokoladnimi sladicami. Dan bi zaključili na Jelenovem grebenu, kjer bi družina večerjala in prespala. Naslednji dan bi se družina po zajtrku lahko odpravila pomagat nahranit jelene, nato bi obiskali Kočo pri čarovnici, kosilo bi imeli pri gostišču Amon, popoldne pa bi preživeli v Family Wellness Thermalia v Termah Olimia. V ceno bi bil vključen tudi prevoz. Okvirno ceno paketa smo ocenili na $360 € /$ osebo.

- Kulinarično doživetje: Predlagamo, da se GIZ poveže z eno od turističnih kmetij, pripravljeno sprejeti goste, ki bi se želeli naučiti, kako pripraviti lokalne jedi, kot je jabolčni štrudelj. Na kmetiji bi imeli tudi kosilo, potem pa bi se odpravili v vinsko klet, kjer bi imeli degustacijo lokalnih vin. V ceno bi bil vključen tudi prevoz. Okvirno ceno paketa smo ocenili na $55 € /$ osebo.

- Foodie experience: Začetek pri vinotoču Martinčič z degustacijo hišnih jedi in vin, nadaljevanje $\mathrm{z}$ degustacijo vin $\mathrm{v}$ Hiši vin Emino, krajše kosilo v Gostišču Jurg in obisk kmetije Štraus, kjer bi imeli delavnico izdelave Bizeljskega ajdovega kolača. Celotni program bi trajal 8 ur (predvidoma od 12. do 20. ure). V ceno bi bil vključen tudi prevoz. Okvirno ceno paketa smo ocenili na $80 € /$ osebo. 
- Zunajsezonski paket: Tudi $\mathrm{v}$ manj obiskanih letnih časih bi ponujali trajnostno obarvane dogodke. Turiste bi peljali na delavnico o ekologiji, trajnosti ter ohranjanju kulture in okolja (za otroke bi bila prilagojena). Sledil bi voden ogled gozda in narave s predstavitvijo rastlinskih vrst, dreves in cvetja. Vse to bi organiziral Zavod Kozjanski park. Potem bi si ogledali sadovnjake (izberemo med več lokalnimi pridelovalci sadja) in dan zaključili v Termah Olimia.

UKREP 4: Ustvarili bi digitalno kulturno ponudbo za otroke. Skupaj s šolami iz destinacije, Fakulteto za turizem UM in Zavodom Kozjanski park bi pripravili interaktivne poučne kvize, $\mathrm{v}$ katerih bi se otroci učili o tradiciji in kulturi destinacije. Kviz bi se lahko izvajal v šoli med poukom ali pa na samem dogodku, ko bi se ta izvajal v živo ali prek spleta. Prav tako pa bi lahko bil kviz del obiska destinacije za vse šolske skupine, ki bi tja prišle na šolsko ekskurzijo.

\section{Cilj 2: Rast števila obiskovalcev kulturnih prireditev}

S kakovostno mednarodno promocijo in oblikovanjem paketnih doživetij bomo dosegli večje število trajnostno zavednih turistov, ki bodo obiskovali naše kulturne prireditve. Akcijski načrt je predstavljen v tabeli 3 . 
Tabela 3: Ukrepi za cilj 2

\begin{tabular}{|l|l|l|l|l|l|}
\hline & & & & \\
& & &
\end{tabular}

UKREP 1: Predlagamo, da destinacija investira v promocijo na Instagram profilu. $\mathrm{V}$ ceno je všteto 6-mesečno plačevanje promocije Instagram računa, kjer Instagram ob rednih objavah na profilu predvideva od 7800 do 21.000 interakcij. Predvidevamo, da si bo s tem destinacija ustvarila dovolj veliko bazo sledilcev na profilu ter bo z rednimi objavami brez promocije pridobivala nove sledilce in potencialne obiskovalce. Predlagamo tudi občasne nagradne igre na Instagramu (izbira najlepše, najbolj smešne, izvirne fotografije, kvizi, nagradna vprašanja), ki bi zagotovo izboljšale promocijo destinacije. Za vsako nagradno igro so pogoji sodelovanja deljenje objave in sledenje Instagram profila (s tem si povečamo bazo potencialnih obiskovalcev, ki jih lahko nato skozi promocijo na profilu privabimo na destinacijo). Če trenutno med zaposlenimi, ki skrbijo za Instagram profil, ni nihče dovolj 
usposobljen za to, se naj udeleži tečaja Instagram marketinga, katerega cena je všteta tudi v finance (Rdeča oranžna d. o. o., 2020).

UKREP 2: Priporočamo, da destinacija nakupi priročen trajnostni promocijski material. V ceno je vštetih 500 lesenih USB-ključkov (1535€), 5000 biorazgradljivih kemičnih svinčnikov (1300 €) in 2000 eko nakupovalnih vrečk (1840 €). Predlagamo, da se nanje natisne logotip, spletna stran in ime družbenega omrežja. Promocijski material bi delili na stojnicah na turističnih sejmih in na prireditvah, kjer bi se predstavljali.

UKREP 3: Predlagamo kombiniranje vstopnic na prireditve s popustom za vstopnice za različna doživetja, kot so degustacije, obiski turističnih kmetij, kosila, delavnice, prevoz, vstopnine za znamenitosti, nočitve ... S tem bi spodbudili obiskovalce, da bi na destinaciji ostali dalj časa, obiskali več ponudnikov in posledično več prispevali k lokalni ekonomiji. Po dogovoru s ponudniki bi oblikovali skupinske vstopnice za vsako prireditev. Predvideni stroški so namenjeni usklajevanju, sestankom s ponudniki in oblikovanju seznama ponudbe.

UKREP 4: V program dogodkov bi še bolj vključevali kulturne vsebine, in sicer s področja gastronomije (degustacija kot promocija lokalnih izdelkov - domače in lokalno vzgojene hrane in pijače), lokalnih obrti (spominki z lokalnimi kulturnimi motivi v obliki lokalnega izdelka, tudi magneta, pisala in podobno) ter tradicije (delavnice za družine, otroke, dijake in študente, upokojence in podobne skupine).

\section{Cilj 3: Povečati število nočitev kulturnih turistov}

Do leta 2025 želimo povečati število nočitev kulturnih turistov v primerjavi z ostalim turisti. Do želenega rezultata bomo prišli z oblikovanjem paketnih doživetij in kakovostno mednarodno promocijo. Akcijski načrt je predstavljen v tabeli 4. 
Tabela 4: Ukrepi za cilj 3

\begin{tabular}{|c|c|c|c|c|c|}
\hline$\frac{1}{2}$ & 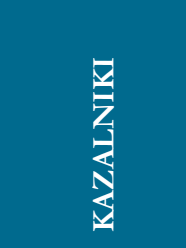 & 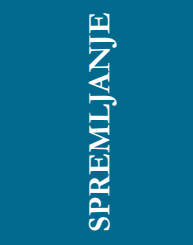 & 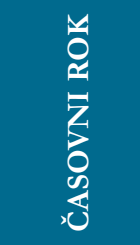 & 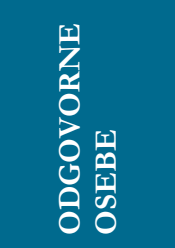 & 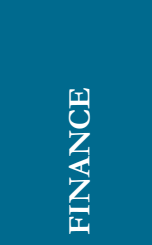 \\
\hline $\begin{array}{l}\text { 1. Prijava na } \\
\text { javne razpise } \\
\text { za pridobitev } \\
\text { finančnih } \\
\text { sredstev za } \\
\text { nadgradnjo } \\
\text { obstoječih } \\
\text { nastanitvenih } \\
\text { kapacitet in } \\
\text { pridobitev } \\
\text { certifikatov } \\
\text { odličnosti }\end{array}$ & $\begin{array}{l}\text { Število } \\
\text { odobrenih } \\
\text { prijav na } \\
\text { razpise, višina } \\
\text { odobrenih } \\
\text { finančnih } \\
\text { sredstev in } \\
\text { pridobljeni } \\
\text { certifikati }\end{array}$ & $\begin{array}{l}\text { Vodenje } \\
\text { statistike prijav } \\
\text { na razpise in } \\
\text { prijav za } \\
\text { pridobivanje } \\
\text { certifikatov }\end{array}$ & $\begin{array}{l}\text { Do konca } \\
\text { leta } 2025\end{array}$ & $\begin{array}{l}\text { Upravljalci } \\
\text { nastanitveni } \\
\text { h obratov, } \\
\text { občina } \\
\text { določi } \\
\text { zaposlenega, } \\
\text { ki jim } \\
\text { pomaga pri } \\
\text { prijavi na } \\
\text { razpise }\end{array}$ & $\begin{array}{c}7000 € \\
\text { (na } \\
\text { ponudnika) }\end{array}$ \\
\hline $\begin{array}{l}\text { 2. Promocija } \\
\text { butičnih } \\
\text { doživetij na } \\
\text { družbenih } \\
\text { omrežjih } \\
\text { skupaj s } \\
\text { promocijo } \\
\text { dogodkov }\end{array}$ & $\begin{array}{l}\text { Število objav } \\
\text { na družbenih } \\
\text { omrežjih }\end{array}$ & $\begin{array}{l}\text { Interakcije s } \\
\text { potencialnimi } \\
\text { gosti pod } \\
\text { objavami in } \\
\text { rezervacije } \\
\text { nastanitev }\end{array}$ & $\begin{array}{l}\text { Do } \\
\text { septembra } \\
2021\end{array}$ & $\begin{array}{l}\text { Turizem } \\
\text { Podčetrtek, } \\
\text { Bistrica ob } \\
\text { Sotli in } \\
\text { Kozje }\end{array}$ & $450 €$ \\
\hline $\begin{array}{l}\text { 3. Oblikovanje } \\
\text { kulturnega } \\
\text { paketa } \\
\text { doživetij }\end{array}$ & $\begin{array}{l}\text { Zanimanje za } \\
\text { paket }\end{array}$ & $\begin{array}{l}\text { Vodenje } \\
\text { evidence } \\
\text { nakupov } \\
\text { paketa }\end{array}$ & $\begin{array}{l}\text { Do } \\
\text { septembra } \\
2021\end{array}$ & $\begin{array}{l}\text { Turizem } \\
\text { Podčetrtek, } \\
\text { Bistrica ob } \\
\text { Sotli in } \\
\text { Kozje }\end{array}$ & $100 €$ \\
\hline $\begin{array}{l}\text { 4. Promocija } \\
\text { turizma zunaj } \\
\text { sezone }\end{array}$ & $\begin{array}{l}5 \text { novih } \\
\text { paketov za } \\
\text { posebne } \\
\text { skupine } \\
\text { turistov } \\
\end{array}$ & $\begin{array}{l}\text { Analiza in } \\
\text { statistika }\end{array}$ & $\begin{array}{l}\text { Zunaj } \\
\text { sezone/sk } \\
\text { ozi celo } \\
\text { leto }\end{array}$ & $\begin{array}{l}\text { Turizem } \\
\text { Podčetrtek, } \\
\text { Bistrica ob } \\
\text { Sotli in } \\
\text { Kozje } \\
\end{array}$ & $3000 €$ \\
\hline
\end{tabular}

UKREP 1: Predlagamo, da se upravljalce nastanitvenih obratov spodbuja $\mathrm{k}$ prijavam na javne razpise na ravni države in Evropske unije z namenom izboljševanja, obnavljanja in gradnje novih nastanitvenih kapacitet. Predlagamo, da ponudnikom občina ali turistična organizacija ponudi zaposlenega, ki jim bo svetoval pri pripravi dokumentacije za razpise in jih obveščal o aktualnih razpisih. Hkrati si želimo, da bi se ponudniki odločili za pridobitev katerega od okoljskih certifikatov. Finančna sredstva, ki smo jih predvideli, so spodbuda za posameznega ponudnika, ki se prijavi 
za pridobitev okoljskega znaka (podatek o višini finančne spodbude smo pridobili na podlagi razpisa Občine Sevnica).

UKREP 2: Predlagamo, da se v času promocije kulturnih prireditev in dogodkov istočasno s promoviranjem le-teh promovirajo tudi ponudniki butičnih doživetij na tem območju. To predlagamo prek plačanih promocijskih objav na Instagram omrežju. V ceno je všteta $3 \times 1$ mesečna promocija objave, ki promovira kulturno prireditev in butična doživetja.

UKREP 3: Predlagamo, da se ob vsaki prireditvi ustvari paket, ki vključuje vstopnino na prireditev, nočitev $\mathrm{v}$ enem od nastanitvenih obratov in naslednji dan aktivnost, ki ju lahko izberejo iz kataloga ponudnikov, ki bi ga ustvarili z namenom prodaje tega paketa, dostopen pa bi bil v elektronski obliki. V finance je vštet strošek grafičnega oblikovanja kataloga.

UKREP 4: Za povečanje števila nočitev bi okrepili ponudbo zunaj sezone. Najprej bi pripravili zunajsezonske turistične pakete, ki ponujajo promocijske degustacije, delavnice, sprehode, kolesarjenja itd., ter jih prilagodili tudi za različne skupine turistov (npr. socialno šibkejše, ljudje s posebnimi potrebami, kot so gibalno ovirani, velike družine, upokojenci ...). Vsak, ki bi izkusil tak paket, bi dobil popust za koriščenje takega paketa naslednje leto zunaj sezone.

\section{Cilj 4: Razpršitev obiskovalcev skozi celotno območje}

Po trenutni situaciji z epidemijo covida-19 se bodo trendi v turizmu spremenili. S tem namenom si želimo razpršiti naše obiskovalce skozi celotno območje destinacije. Po trenutnih podatkih je namreč večinski delež turistov $\mathrm{v}$ občini Podčetrtek z nastanitvijo v sklopu Term Olimia. Ta delež nameravamo zmanjšati tako, da bomo goste preusmerili v nove nastanitve in atrakcije v občinah Kozje (na Gradu Podsreda) in Bistrica ob Sotli. Akcijski načrt je predstavljen v tabeli 5. 
Tabela 5: Ukrepi za cilj 4

\begin{tabular}{|l|l|l|l|l|l|}
\hline & & & &
\end{tabular}

UKREP 1: Predlagamo, da se v eni od občin (Bistrica ob Sotli ali Kozje) zgradi eko glamping resort, s katerim bodo privabili obiskovalce na območje, kjer še ni masovnega obiska. V načrtovanju resorta je treba misliti na trajnost in povzročanje čim manjšega vpliva na okolje. Predlagamo, da se v gradnjo vključi lokalna podjetja, les iz lokalnih gozdov, po koncu gradnje pa lahko za goste pripravijo pletene košarice, $v$ katerih jim postrežejo zajtrk lokalnih pridelovalcev. Občina bi lahko sama zgradila resort ter pridobila sredstva iz evropskih in državnih razpisov ali pa poiskala zasebnega investitorja. V finance smo všteli okvirno ceno 10 glamping hišk (10.000 $€ /$ hiško) ter ureditev primernega prostora $\mathrm{z}$ infrastrukturo za postavitev glamping resorta in promocijo. 
UKREP 2: Predlagamo, da občini Kozje in Bistrica ob Sotli kontaktirata podjetje Klopca ljubezni in predlagata vsaka eno fotografsko privlačno točko, kjer bi postavili klopco ljubezni. Za občino Bistrica ob Sotli predlagamo postavitev nad Sotesko reke Bistrice, v občini Kozje pa na Vetrniku. Podjetje Klopca ljubezni bi izbrali zato, ker bi s tem poskrbeli za samo promocijo klopic.

UKREP 3: Predlagamo, da se v občini Kozje postavi parkirišče za avtodome, ki se nato vpiše $v$ register avtodom postajališč, saj smo opazili, da je zaenkrat na tem območju le eno parkirišče za avtodome, in sicer pri gostišču Amon. Za tega predlagamo, da se uredi tudi možnost oskrbe avtodoma z elektriko, vodo in priklopom na kanalizacijo za odplake. V finance smo všteli približno ceno za postavitev 10 mest za avtodome.

UKREP 4: Prvi korak za spremljanje obiska je definiranje trenutnih lokacij, ki jih obiskujejo turisti. Če vemo, kje so, jih lahko usmerimo na druge točke. Če želimo, da je na posameznih točkah manj gneče, lahko turistom določimo tudi časovni interval, v katerem smejo biti na območju. To bi naredili z vzpostavitvijo aplikacije za nadzor števila obiskovalcev. Hkrati pa bi v tej aplikaciji turisti dobili koristne informacije o destinaciji, kaj bi si bilo v tem trenutku najbolj smiselno ogledati, kje jesti - predvsem tam, kjer trenutno ni presežena nosilna zmogljivost. Tistim, ki bi aplikacijo uporabljali, bi lahko podelili kupone za popust ali gratis izdelke/storitve.

UKREP 5: Da bi dosegli razpršitev turistov in s tem boljšo kakovost življenja na destinaciji, je pomembno vključevanje lokalnih prebivalcev v vse vidike turizma. Pogosto domačini ne vedo, zakaj se določene stvari naredijo, in tudi ne vedo, kako lahko kaj naredijo glede tega. Zato je zelo pomembno vključiti domačine v vse pomembne odločitve, ki se dogajajo na tem območju. Zelo dobra ideja za izboljšanje kakovosti življenja domačinov je, da se najprej oni udeležijo turističnih tur in tako izkusijo, kaj turisti plačajo in kje so priložnosti za vključevanje lokalnega prebivalstva $\mathrm{v}$ te oglede. 


\section{Cilj 5: Okrepitev promocije in povečanje mednarodne prepoznavnosti kulturnih prireditev na destinaciji}

Do leta 2025 želimo, da bi kulturne prireditve na destinaciji Podčetrtek, Bistrica ob Sotli in Kozje postale bolj mednarodno prepoznavne s pomočjo družbenih omrežij, televizije, večjezičnih brošur in obiskovanja mednarodnih sejmov. Akcijski načrt je predstavljen $\mathrm{v}$ tabeli 6 .

\section{Tabela 6: Ukrepi za cilj 5}

\begin{tabular}{|c|c|c|c|c|c|}
\hline 氛 & $\frac{\mathbb{Z}}{Z}$ & 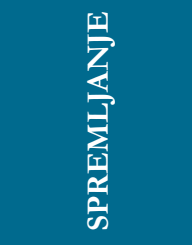 & 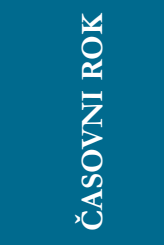 & $\begin{array}{l}\frac{1}{7} \\
\frac{2}{6} \\
0 \\
8 \\
0 \\
0 \\
0 \\
0 \\
0 \\
0\end{array}$ & 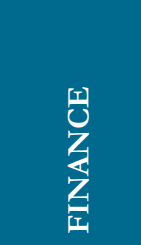 \\
\hline $\begin{array}{l}\text { 1. Oblikovanje } \\
\text { tujejezičnih } \\
\text { brošur }\end{array}$ & $\begin{array}{l}\text { Število } \\
\text { razdeljenih } \\
\text { brošur (3 } \\
\text { jeziki x } 1000 \\
\text { brošur) }\end{array}$ & $\begin{array}{l}\text { Štetje in } \\
\text { vodenje } \\
\text { statistike } \\
\text { deljenja brošur }\end{array}$ & $\begin{array}{l}\text { Do začetka } \\
\text { leta } 2022\end{array}$ & $\begin{array}{l}\text { Turizem } \\
\text { Podčetrtek, } \\
\text { Bistrica ob } \\
\text { Sotli in Kozje } \\
\text { - GIZ }\end{array}$ & $530 €$ \\
\hline $\begin{array}{l}2 . \\
\text { Obiskovanje } \\
\text { turističnih } \\
\text { sejmov }\end{array}$ & $\begin{array}{l}\text { Število } \\
\text { pridobljenih } \\
\text { kontaktov in } \\
\text { ponudb }\end{array}$ & $\begin{array}{l}\text { Vodenje } \\
\text { kontaktov, } \\
\text { ponudb in } \\
\text { okvirnega } \\
\text { števila } \\
\text { obiskovalcev }\end{array}$ & $\begin{array}{l}\text { Do konca } \\
\text { leta } 2022\end{array}$ & $\begin{array}{l}\text { Turizem } \\
\text { Podčetrtek, } \\
\text { Bistrica ob } \\
\text { Sotli in Kozje } \\
\text { - GIZ }\end{array}$ & $\begin{array}{l}2000 \\
€ / \text { sejem }\end{array}$ \\
\hline $\begin{array}{l}\text { 3. Nakup } \\
\text { promocijskih } \\
\text { pripomočkov }\end{array}$ & $\begin{array}{l}\text { Vodenje } \\
\text { evidence } \\
\text { uporabe } \\
\text { pripomočko } \\
\text { v } \\
\end{array}$ & $\begin{array}{l}\text { Vodenje } \\
\text { evidence } \\
\text { uporabe } \\
\text { pripomočkov }\end{array}$ & $\begin{array}{l}\text { Do začetka } \\
\text { leta } 2022\end{array}$ & $\begin{array}{l}\text { Turizem } \\
\text { Podčetrtek, } \\
\text { Bistrica ob } \\
\text { Sotli in Kozje } \\
\text { - GIZ }\end{array}$ & $1135 €$ \\
\hline $\begin{array}{l}\text { 4. Promocija } \\
\text { na spletu }\end{array}$ & $\begin{array}{l}\text { Število } \\
\text { ogledov } \\
\text { oglasov na } \\
\text { IG (10.000 } \\
\text { ogledov) } \\
\text { Objavljen } \\
\text { članek v } \\
\text { spletni reviji } \\
\text { tipTravel } \\
\text { Delujoča } \\
\text { mobilna } \\
\text { aplikacija }\end{array}$ & 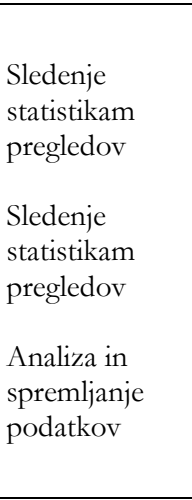 & $\begin{array}{l}6 \text { mesecev, } \\
\text { julij } 2021 \\
1 \text { mesec, } \\
\text { avgust } 2021 \\
\text { September } \\
2021\end{array}$ & $\begin{array}{l}\text { Strokovnjaki } \\
\text { za trženje in } \\
\text { za odnose z } \\
\text { javnostmi } \\
\\
\text { Visit } \\
\text { Podčetrtek, } \\
\text { Turistično } \\
\text { društvo } \\
\text { Podčetrtek }\end{array}$ & $\begin{array}{l}500 € \mathrm{za} \\
\text { aplikacijo, } \\
2000 € \mathrm{za} \\
\text { nagradno } \\
\text { igro in } \\
\text { promocijo }\end{array}$ \\
\hline
\end{tabular}




\begin{tabular}{|c|c|c|c|c|c|}
\hline$\frac{\overrightarrow{2}}{\sqrt[c]{x}}$ & $\frac{\sqrt{6}}{Z}$ & 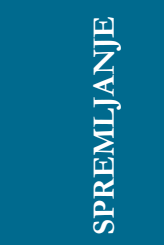 & 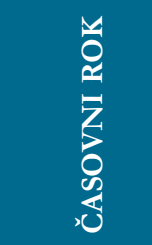 & $\begin{array}{l}\frac{1}{7} \\
\frac{2}{0} \\
0 \\
8 \\
0 \\
0 \\
0 \\
0 \\
0\end{array}$ & 岳 \\
\hline & $\begin{array}{l}\text { destinacije } \\
(60 \% \\
\text { obiskovalcev } \\
\text { jo uporablja) }\end{array}$ & & & & \\
\hline $\begin{array}{l}\text { 5. Promocija s } \\
\text { plakati }\end{array}$ & $\begin{array}{l}10 \text { jumbo } \\
\text { plakatov na } \\
\text { najbolj } \\
\text { prometnih } \\
\text { lokacijah }\end{array}$ & $\begin{array}{l}\text { Spremljanje } \\
\text { terena }\end{array}$ & $\begin{array}{l}\text { Avgust, } \\
\text { september } \\
2021\end{array}$ & Oko Media & $8000 €$ \\
\hline $\begin{array}{l}\text { 6. Promocija } \\
\text { na šolah in } \\
\text { fakultetah }\end{array}$ & $\begin{array}{l}\text { Promocije na } \\
5 \text { OŠ, } 5 \text { SS in } \\
5 \text { fakultetah }\end{array}$ & $\begin{array}{l}\text { Vodenje } \\
\text { evidence } \\
\text { obiska }\end{array}$ & $\begin{array}{l}\text { September } \\
2021\end{array}$ & $\begin{array}{l}\text { Turistično } \\
\text { društvo } \\
\text { Podčetrtek, } \\
\text { Visit } \\
\text { Podčetrtek }\end{array}$ & $1500 €$ \\
\hline
\end{tabular}

UKREP 1: Predlagamo, da se za promocijo izdela brošura, ki predstavlja destinacijo in njene aktivnosti. Velikost brošure bi bil list formata A4, ki bi bil dvakrat prepognjen (ena stran je 1/3 A4 - 6 strani). Prevede naj se še v nemški in angleški jezik, vsake brošure po 1000 kopij (prevajalstvo 41,80 €) (Multilingual, 2008-2013). Odgovorna za izvedbo ukrepa bi bila organizacija Turizem Podčetrtek, Bistrica ob Sotli in Kozje. Tisk 3000 brošur smo ocenili na 432,09€ (Demago, 2020). V strošek je vštet tudi predviden strošek $50 €$ za oblikovanje brošure. Brošure bi delili na turističnih sejmih, borzah in dogodkih, kjer bi se promovirali, na voljo pa bi bile tudi pri ponudnikih nastanitev. Za tiskane brošure smo se odločili, saj vsi ponudniki še nimajo potrebne opreme za digitalne brošure.

UKREP 2: Predlagamo, da se turistična organizacija udeleži raznih turističnih sejmov, na katerih zakupi razstavni prostor in promovira destinacijo. Izračun za finance je izdelan na podlagi Berlinske turistične borze ITB Berlin (najem prostora 1829,60 € za razstavni prostor $2 \mathrm{~m}$ x $3 \mathrm{~m}$ ) (Messe Berlin, 2020). Zraven smo prišteli še okvirne potne stroške (prevoz s kombijem in nastanitev). 
UKREP 3: Za promocijo destinacije priporočamo nakup promocijskih pripomočkov, ki so naložba v prihodnost, saj jih lahko uporabljajo več let. $\mathrm{V}$ ceno je vštet nakup obojestranskega promocijskega roll up stojala $(295,53 €-2 \mathrm{~m} \times 1 \mathrm{~m})$, stojala za prospekte $(422,73 €-1,8 \mathrm{~m} \times 0,5 \mathrm{~m})$ in promocijskega pulta $(415,98 €-$ $0,9 \mathrm{~m} \times 1,5 \mathrm{~m}$ ) (Demago, 2020). Pripomočke bi tako lahko uporabljali pri promociji na sejmih, vseh prireditvah in $\mathrm{v}$ turistično-informacijskem centru.

UKREP 4: S promocijo se znanje o destinaciji širi na vse generacije - mlade, srednje in starostnike, pa tudi na turiste različnih tipov. Promocija poteka prek spleta z uporabo različnih kanalov. Zelo uporabna so družbena omrežja, kjer bi morali najprej ugotoviti trende uporabe različnih skupin turistov. Eden od teh kanalov je aplikacija Instagram, ki jo uporabljajo predvsem mladi in ljudje srednjih let. Plačljiva promocija na Instagramu je sodoben način oglaševanja, pri tem so pomembni vplivneži (influencerji). Druga pot je prek spletne revije Lonely Planet, kjer bi lahko dosegli širše občinstvo turistov srednjih let in starejše. Za večjo prepoznavnost bi oblikovali mobilno aplikacijo, s katero bi lahko obiskovalci spoznali destinacijo, dogodke, restavracije, vremensko napoved in mogoče spremembe ter se prijavili na nagradno igro ali se vključili v lov na zaklad. Mobilna aplikacija bi bila promovirana na družbenih omrežjih.

UKREP 5: Za promocijo s plakati bi vzeli jumbo plakate in jih postavili na dele, ki so bolj prometni (kot so avtoceste, $\mathrm{v}$ bližini trgovin, nakupovalnih centrov in podobno). Postavili bi 10 jumbo plakatov, in sicer za dva tedna. Predvideli smo 8000 $€$.

UKREP 6: Kot zadnji ukrep smo izbrali promocijo na osnovnih šolah, srednjih šolah in fakultetah. Predstavitev bi se organizirala en mesec do dva tedna pred dogodkom.

\section{Cilj 6: Dokončno izločiti plastično embalažo na prireditvah in jo nadomestiti z biorazgradljivo}

Do leta 2025 želimo dokončno izločiti nerazgradljivo embalažo in pripomočke (kozarci, pribor, embalaža) ter jih nadomestiti s produkti za večkratno uporabo ali tistimi, ki so biorazgradljivi. S tem želimo zmanjšati število odpadkov na prireditvah, katerih poslovanje bo zaradi tega bolj trajnostno. Akcijski načrt je predstavljen v tabeli 7 . 


\section{Tabela 7: Ukrepi za cilj 6}

\begin{tabular}{|l|l|l|l|l|l|}
\hline & & & \\
& & &
\end{tabular}

UKREP 1: Predlagamo, da občine začnejo intenzivno spodbujati organizatorje prireditev $\mathrm{k}$ popolni izločitvi pribora iz netrajnostnih materialov in začnejo uporabljati biorazgradljivega oziroma za večkratno uporabo. K temu bi jih lahko spodbujali z delnim sofinanciranjem pribora. V finance je vštetih 2000 enot bio priborov (Spar Slovenija trgovsko podjetje d.o.o., b. d.). 
UKREP 2: Predlagamo, da se ob prodaji izdelkov na prireditvah uporabljajo trajnostni materiali, kot so platnene ali papirnate vrečke, za večje količine sadja pa kartonaste ali lesene zabojčke. V ceno je vštetih 200 kartonastih zabojčkov $102,77 €($ UnitPAC, 2020) in 1000 nosilnih papirnatih vrečk - $340 €$ (Moja Košarica, b. d.).

UKREP 3: Predlagamo, da se ob dogodkih, kjer gostom strežejo pijačo, le ta postreže v embalaži za večkratno uporabo, kot so steklenice, vrči in kozarci za večkratno uporabo. Na dogodkih, kjer degustirajo hrano in pijačo po različnih stojnicah, predlagamo kavcijski sistem, kjer bi obiskovalci plačali kavcijo za prejem kozarca, pribora ali krožnika in ga po uporabi vrnili in dobili nazaj kavcijo, lahko pa kozarec tudi obdržijo za spomin (brez vrnitve kavcije). V finance je vštet nakup 2000 kozarcev z graviranjem (Graviart d. o. o., 2018).

UKREP 4: Danes je turizem brez odpadkov nujen, lokalni ponudniki storitev pa so zagotovo zelo pomembni pri zagotavljanju tega standarda. Zato predlagamo, da se o »zero waste« turizmu poučijo na izobraževanju, na katerem se bodo spoznali z ločevanjem odpadkov in recikliranjem ter $z$ neškodljivimi materiali za uporabo na dogodkih.

\section{Cilj 7: Hitro okrevanje po preklicu epidemije}

Po epidemiji se bo način dela $\mathrm{v}$ turizmu spremenil, na kar se bomo pripravili $\mathrm{z}$ izobraževanjem naših zaposlenih, možnostmi za izvajanje dogodkov in ogledov znamenitosti prek spleta. Akcijski načrt je predstavljen v tabeli 8 . 
Tabela 8: Ukrepi za cilj 7

\begin{tabular}{|c|c|c|c|c|c|}
\hline 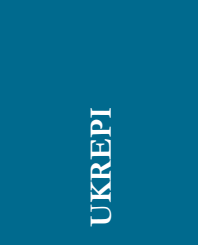 & $\underset{\mathbb{Z}}{\mathbb{Z}}$ & 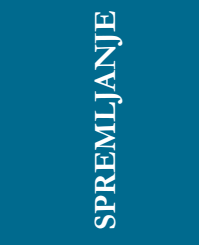 & 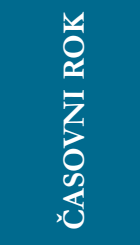 & 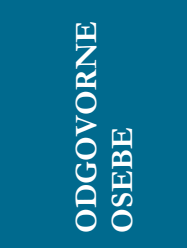 & 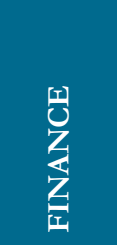 \\
\hline $\begin{array}{l}\text { 1. Izvedba } \\
\text { spletnih } \\
\text { dogodkov } \\
\text { (ohranjanje } \\
\text { dogajanja in } \\
\text { promocije) }\end{array}$ & $\begin{array}{l}\text { Število ogledov } \\
\text { dogodkov, } \\
\text { število } \\
\text { interakcij, } \\
\text { število } \\
\text { udeležencev }\end{array}$ & $\begin{array}{l}\text { Vodenje } \\
\text { evidence }\end{array}$ & $\begin{array}{l}\text { Do marca } \\
2021\end{array}$ & $\begin{array}{l}\text { Organizatorji } \\
\text { dogodkov in } \\
\text { upravljalci } \\
\text { atrakcij }\end{array}$ & $1000 €$ \\
\hline $\begin{array}{l}\text { 2. Nakup } \\
\text { okolju prijazne } \\
\text { opreme za } \\
\text { zagotavljanje } \\
\text { varnostne } \\
\text { razdalje na } \\
\text { dogodkih }\end{array}$ & $\begin{array}{l}\text { Zanimanje za } \\
\text { opremo s strani } \\
\text { organizatorjev } \\
\text { dogodkov }\end{array}$ & $\begin{array}{l}\text { Najemanje } \\
\text { opreme, } \\
\text { vodenje } \\
\text { evidence }\end{array}$ & $\begin{array}{l}\text { Do maja } \\
2021\end{array}$ & $\begin{array}{l}\text { Občina } \\
\text { Podčetrtek, } \\
\text { Občina Kozje }\end{array}$ & $10.000 €$ \\
\hline $\begin{array}{l}3 . \\
\text { Izobraževanje } \\
\text { zaposlenih v } \\
\text { turizmu in } \\
\text { gostinstvu o } \\
\text { zdravstveni } \\
\text { varnosti }\end{array}$ & $\begin{array}{l}\text { Število prisotnih } \\
\text { na } \\
\text { izobraževanjih }\end{array}$ & $\begin{array}{l}\text { Evidenca } \\
\text { prisotnosti, } \\
\text { upoštevanje } \\
\text { ukrepov, } \\
\text { anketa/mini } \\
\text { test }\end{array}$ & $\begin{array}{l}\text { Do marca } \\
2021\end{array}$ & $\begin{array}{l}\text { GIZ, } \\
\text { ponudniki so } \\
\text { odgovorni, da } \\
\text { prijavijo svoje } \\
\text { zaposlene }\end{array}$ & $10.500 €$ \\
\hline $\begin{array}{l}\text { 4. Spremljanje } \\
\text { obiskovalcev s } \\
\text { pomočjo QR- } \\
\text { kode in nadzor } \\
\text { števila } \\
\text { udeležencev }\end{array}$ & $\begin{array}{l}\text { Kodo bi } \\
\text { skeniralo vsaj } \\
60 \% \\
\text { obiskovalcev }\end{array}$ & $\begin{array}{l}\text { Sledenje } \\
\text { aplikacijam } \\
\text { prek QR-kode }\end{array}$ & $\begin{array}{l}\text { Skozi celo } \\
\text { leto }\end{array}$ & GIZ & $2500 €$ \\
\hline $\begin{array}{l}\text { 5. Virtualna } \\
\text { izkušnja } \\
\text { destinacije } \\
\end{array}$ & $\begin{array}{l}\text { Število } \\
\text { uporabnikov } \\
\text { VR-izkušnje } \\
\end{array}$ & $\begin{array}{l}\text { Statistika } \\
\text { uporabe }\end{array}$ & $\begin{array}{l}\text { Do konca } \\
2022 \text {. }\end{array}$ & GIZ, občine & $13.000 €$ \\
\hline $\begin{array}{l}\text { 6. Izvajanje } \\
\text { zaščitnih } \\
\text { ukrepov na } \\
\text { destinaciji }\end{array}$ & $\begin{array}{l}\text { Postavitev } \\
\text { prostorov za } \\
\text { razkuževanje in } \\
\text { testiranje, pisna } \\
\text { opozorila glede } \\
\text { ukrepov, } \\
\text { prisotnost } \\
\text { maskote } \\
\text { »lovenski } \\
\text { Bambi« }\end{array}$ & $\begin{array}{l}\text { Nadzor lokacij } \\
\text { in ukrepov }\end{array}$ & $\begin{array}{l}\text { Do konca } \\
\text { epidemije }\end{array}$ & $\begin{array}{l}\text { Ponudniki, } \\
\text { zdravstvene } \\
\text { službe }\end{array}$ & $5000 €$ \\
\hline
\end{tabular}


UKREP 1: Predlagamo, da se $\mathrm{v}$ času epidemije in zaprtja javnega življenja na družabnih omrežjih še vseeno ohranja dogajanje. Predlagamo razne literarne večere, delavnice, predstavitve znamenitosti, plačljive virtualne oglede muzejev in nagradne igre. Lahko se tudi dogovorijo z lokalnimi glasbeniki za koncert $\mathrm{v}$ spletni obliki. V finance smo všteli stroške priprave dogodkov, promocije in dogovorov $\mathrm{z}$ nastopajočimi in ponudniki.

UKREP 2: Predlagamo, da občina ali GIZ nakupi opremo za zagotavljanje varnostne razdalje na prireditvah (ograje), s katerimi lahko potem oblikujemo cone, za katere določimo dovoljeno število obiskovalcev, ki so lahko naenkrat v njej glede na trenutne predpise. $\mathrm{Na}$ vstopna mesta $\mathrm{v}$ cone bi postavili redarje, ki bi skrbeli za primerno število oseb $\mathrm{v}$ conah. $\mathrm{V}$ finance je vštet nakup $150 \mathrm{~m}$ usmerjevalnih ograj $(1,5 \mathrm{~m}-100 €)$ (Styria digital marketplaces d.o.o., 2020). Občina bi lahko nato ponudnikom ograje ponujala $\mathrm{v}$ najem za pripravo varnega prireditvenega prostora.

UKREP 3: Predlagamo, da se organizira izvedba predavanja za zaposlene $\mathrm{v}$ gostinstvu in turizmu o varovanju zdravja na delovnem mestu s poudarki na trenutni pandemiji, kjer bi se jim predstavilo, kako zagotavljati osebno zdravstveno varnost in skrbeti za varstvo zdravja drugih, kot so sodelavci in gostje. S tem bi bili tudi usposobljeni, da zainteresiranim obiskovalcem podajo lahko dostopne informacije in jim omogočijo pogovor, če imajo vprašanja, priporočila ali povratne informacije. V finance so vštete cene seminarja za 300 oseb. Ker nismo zasledili tovrstnega seminarja, smo vzeli najbolj podobnega - tečaj varstva pri delu. Predlagamo, da občina ponudnikom sofinancira stroške seminarja.

UKREP 4: Pred vhodom v objekte bi postavili QR-kode in spodbudili obiskovalce, da kodo skenirajo. S tem bi lažje kontrolirali gibanje obiskovalcev in sporočali o pojavu morebitne okužbe. S skeniranjem kode bi se obiskovalci udeležili tudi nagradne igre, kar bi povečalo število ljudi, ki bi kodo dejansko uporabljali. S pomočjo kode bi se tudi zagotavljal nadzor nad številom udeležencev, ki bi se po potrebi omejil, če bi se dogodka želelo udeležiti več oseb, kot je dovoljeno.

UKREP 5: Na destinaciji bi vzpostavili ponudbo doživetij VR (virtualna resničnost). Opremili bi lahko muzeje oziroma kulturne zbirke, omogočili virtualni sprehod skozi kraje po urbani ali naravni krajini. Tako bi si lahko ogledali trenutno destinacijo in tudi virtualni prikaz preteklosti, s spoznavanjem tradicionalne arhitekture in 
podobno. Za projekt bi lahko pridobili evropska sredstva. VR-izkušnja bi bila namenjena tudi promociji na domačem in mednarodnem trgu.

UKREP 6: V času predpisanih ukrepov bi morali na destinaciji skrbeti za njihovo dosledno izvajanje. Tako bi imeli povsod zagotovljen prostor za razkuževanje rok, opozorila za nošenje mask in možnosti hitrega testiranja. Za bolj prijazen način opozarjanja na ukrepe bi lahko uporabili maskoto »slovenski Bambi«, ki bi ponazarjala razdaljo, ki mora biti med ljudmi. Tako bi lažje razumeli, kolikšna je zaželena fizična razdalja. Hkrati pa bi ta maskota odgovarjala na vprašanja glede varnosti in zaščite, za kar bi morali biti usposobljeni tudi organizatorji prireditve. 
PRIPOROČILA ZA ZELENE PRIREDITVE: PRIMER PRIREDITVE PRAZNIK KOZJANSKEGA JABOLKA 
Poglavlje 6

\title{
Smernice za trajnostne prireditve na destinaciji Podčetrtek, Bistrica ob Sotli in Kozje
}

\author{
LuKas Deu, Simon DORFFner, IMELdA FeLIĆ, LARA Fudurić, \\ JoŠKo Glavina, Luka GoŠEK, TENa Gregorić, Sara Horvat, \\ Iva Jerotijević, Patricija Kelhar, Franjo Krapec, Katja Magdič, \\ Nikola Mahnić, Petar Milošević, Eva Pašalić, Janko Pelikan, \\ MARIJA PRISTAŠ IN LOVRO VITKO
}

Oblikovane so bile splošne smernice za trajnostno poslovanje prireditev na destinaciji Podčetrtek, Bistrica ob Sotli in Kozje.

\subsection{Splošne trajnostne smernice}

Dogodki na destinaciji so izjemnega pomena za širitev turistične ponudbe destinacije. Destinacija lahko ponudi različne oblike prireditev, pri tem pa bi morala $\mathrm{v}$ prihodnosti vsekakor razmisliti o načrtovanju in organizaciji dogodkov, ki so v skladu s trajnostnim razvojem. Obstaja več smernic, ki se jih mora držati organizator prireditve, če želi vzpostaviti dogodek, ki je okolju prijazen (MORPC, EPA in 
SWACO, 2014). Pri vseh teh dogodkih je zelo pomembno, da smo pozorni na nekaj postavk, ki so izjemno pomembne pri organizaciji trajnostnega dogodka. To so zagotovo lokacija in infrastruktura, naravno okolje, mobilnost, energija, odpadki, hrana in pijača, voda, družbena odgovornost ter oglaševanje ali promocija dogodkov (Mestna občina Ljubljana, 2015). Vsak dogodek, ki je okoljsko oz. trajnostno naravnan, bi moral biti skladen s smernicami trajnostnega razvoja, ki jih predstavljamo v nadaljevanju.

\section{(i) Lokacija}

Priporočamo izbiro lokacij z dobro razvito infrastrukturo - npr. razvit sistem odlaganja odpadkov, ki je varen za organizatorje, obiskovalce in udeležence; vrhunsko opremo za različne prireditve, da se zmanjšajo stroški dela. Priporoča se uporaba lokalnih gradbenih materialov (npr. les) ter infrastruktura za večkratno uporabo. Namestitve za obiskovalcev naj bodo čim bližje lokaciji prireditve, da je osrednje prizorišče dosegljivo peš.

Predlagamo, da se dogodek organizira na prostem; če pride do slabega vremena (dežja ali močnega vetra), se premakne en teden naprej. Opcija je tudi, da se lokacija dogodka (npr. festivala) preselili v notranje objekte - varianta B. Tukaj se lahko uporabi športna dvorana Podčetrtek ali pokrito parkirišče nakupovalnega središča ali supermarketa, upoštevajo pa se tudi garažne hiše na tem območju, pod pogojem, da so pokrite. Treba je organizirati ekipo, ki bo načrtovala, izvajala in spremljala dogodek (pred, med in po npr. festivalu), da bi se organizatorji lahko vsemu prilagodili.

\section{(ii) Mobilnost}

Kar zadeva mobilnost, priporočamo trajnostno potovanje, in sicer, če je mogoče, prihod z vlakom in organiziranim prevozom do destinacije, lahko tudi z uporabo električnega avtobusa. Obiskovalci bi električni javni prevoz za dostop do določenega dogodka uporabili zato, da bi zmanjšali onesnaženost zraka in ne bi bili obremenjeni s parkiranjem. Obiskovalcem priporočamo tudi, da pridejo na prireditev peš ali s kolesom. 
Kar zadeva samo mobilnost, predlagamo nakup mestnih električnih avtobusov/avtomobilov/koles, ki bi zmanjšali onesnaževanje okolja. Prav tako bi lahko ponudbi mestnih koles dodali še mestne električne skuterje, s katerimi bi si lahko ogledali znamenitosti destinacije.

\section{(iii) Energija}

Glasnost zvočnikov je treba prilagoditi (brez posebnih učinkov, ne preveč na glas največ $80 \mathrm{db}$ ) in osvetliti samo potrebne dele prizorišč. Za to predlagamo uporabo luči s senzorji (npr. v straniščih). Če se dogodek odvija na prostem, je treba biti pozoren na ptice, ki jih moti močna razsvetljava. Ko govorimo o energiji in varčevanju, je pomembno, da se držimo smernic, povezanih s trajnostnim razvojem. Pomembno je biti pozoren na prihranke energije in zagotoviti, da se energija ne izgublja po nepotrebnem. Če je le mogoče, je treba uporabljati naravno svetlobo in ne trošiti energije na načine, ki niso potrebni. Treba je uporabiti obnovljive vire (npr. sončne kolektorje) in ne dodatno onesnaževali okolja s proizvodnjo energije. Takšna naložba se lahko financira iz različnih subvencij države ali občine. Smiselno se je izogibati uporabi virov energije (npr. generatorjem), ki dodatno onesnažujejo okolje.

$\mathrm{Na}$ destinaciji bi lahko razmislili o oblikovanju polj sončnih kolektorjev, s katerimi bi se lahko proizvajala elektrika za celotno destinacijo oziroma dogodke. Prav tako je možna tudi zasnova območij zbiranja deževnice, od koder bi pozneje namakali polja, ki so pomembna in ključna za razvoj kmetijstva na tem območju. S tem bi se zmanjšali stroški kmetov in tudi drastično izboljšalo življenje ljudi na lokaciji. Tudi za te projekte bi lahko pridobili sredstva iz Evropske unije ter certifikate za zeleni in trajnostni razvoj (npr. »zero waste«). Sama občina bi ravnala odgovorno in napredno ter ponujala nova delovna mesta strokovnjakom na teh področjih.

\section{(iv) Odpadki}

Trajnost naravnega okolja je zelo pomembna, zato priporočamo uporabo izdelkov, ki so minimalno škodljivi, npr. uporabo recikliranega materiala brez plastike, uporabo naravnih čistilnih in razkuževalnih sredstev za zmanjšanje škodljivih učinkov kemikalij. Za zmanjšanje količine odpadkov priporočamo uporabo steklenih kozarcev za pitje. Obiskovalec bi plačal kozarec in ga moral uporabljati ves čas prireditve. Pijačo bi si natočil na predvidenih aparatih in kozarec po koncu vrnil. 
Kar zadeva hrano, predlagamo uporabo kartonskih krožnikov/posod ali uporabo porcelanskih pripomočkov in kozarcev. Prav tako je priporočilo, da na stojnicah ne ponujajo plastičnih vrečk, ampak papirnate, lahko pa obiskovalec vrečko prinese s sabo. Na več mestih je treba postaviti koše za ločevanje odpadkov.

\section{(v) Hrana in voda}

Hrana in pijača sta dva od najpomembnejših delov vsakega dogodka, zato jima je treba posvetiti posebno pozornost pri organizaciji trajnostnih dogodkov. S ponudniki hrane in pijače se sklene dogovor o trajnostnem ravnanju ter ponujanju lokalne in sezonske hrane, o kateri tudi ozaveščajo udeležence. Pomembno je vključiti ekološko pridelana živila lokalnih dobaviteljev, da se zagotovi kratka dobavna veriga »od vil do vilic«. Predlagamo tudi uporabo posod za večkratno uporabo, skodelic, kozarcev, krožnikov, skled ali košar, da bi odpravili nepotrebne odpadke in izločili plastiko. Uporaba biološko razgradljivih materialov pri ponudbi jedi je izjemnega pomena. Stekleni kozarci so eden od načinov, da se prepreči prekomerna uporaba plastike za enkratno rabo. Pomembno je tudi, da po prireditvi poteka recikliranje posode. Presežna hrana, ki je užitna in primerna za prehranjevanje, se ponudi v dobrodelne namene. Hrano, ki ni namenjena nadaljnji uporabi, je treba reciklirati v biološke odpadke ali kompost. Vse večje kose odpadkov je treba odpeljati na reciklažno dvorišče.

Voda je osnova za številne prireditve. Čeprav ni samo za pitje, je v mnogih drugih situacijah zelo pomembna. Voda in njena prekomerna uporaba, raztros pitne vode in podobno vodijo do nepotrebne uporabe pitne vode. Na prireditvah z zabavno, umetniško ali športno vsebino je ključnega pomena varčevanje $z$ vodo.

\section{(vi) Družbena odgovornost}

Družbena odgovornost je skupaj z vsemi drugimi naštetimi dejavniki zelo pomemben primer smernic, po katerih je treba izpeljati dogodek, da postane trajnosten. Družbena odgovornost podjetij je ena najpomembnejših tem $\mathrm{v}$ korporativnem smislu. Ta sklop zagotovo vključuje odgovorno vedenje, pa tudi vedenje $\mathrm{v}$ skladu s trajnostnim razvojem za vse ponudnike izdelkov ali storitev na samem dogodku. Med prednosti za ponudnike storitev, ki ustrezajo trajnostnemu razvoju, lahko štejemo: povečanje prodaje in tržnega deleža, krepitev pozicije 
blagovne znamke, krepitev podobe in vpliva podjetja, krepitev sposobnosti privabljanja, motiviranja in zadrževanja zaposlenih, zmanjšanje poslovnih stroškov in povečanje privlačnosti za vlagatelje in finančne analitike. Zagotovo je eden od ciljev trajnostne prireditve, da prispeva h koristim celotne skupnosti.

$\mathrm{V}$ primeru slabe letine zaradi vremenskih razmer ter majhne pridelave jabolk in drugih pridelkov imajo težave vsi pridelovalci. S pomočjo sredstev, zbranih na dogodkih, bi lahko občine pomagale lokalnim ponudnikom pri posodobitvi in izboljšanju tehnologije pridelave sadja in zelenjave. Za primere suhih obdobij bi lahko postavili namakalne sisteme, $\mathrm{v}$ primerih slane oziroma pozebe bi organizirali zaščito sadovnjakov in vinogradov, $\mathrm{v}$ primerih toče pa postavili zaščitne mreže. Občina bi lahko pomagala tudi z znižanjem stroškov ponudnikom na dogodkih, da bodo lažje nadomestili škodo na propadlih sadnih drevesih.

Med splošnimi smernicami družbene odgovornosti pa je tudi skrb za turiste, ki so vir prihodkov. Najpomembnejše je njihovo zadovoljstvo, ki v veliki meri jamči, da se bodo prihodnje leto vrnili, da bodo dogodek znova obiskali. Zato jim moramo pokazati, da smo inovativni in da jih bomo z veseljem spet gostili. Pri tem moramo slediti trendom in se prilagoditi občinstvu, ki ga nagovarjamo. Natančneje, ne želimo na enak način predstaviti vsebin otrokom in odraslim, zato bomo spremenili način komunikacije in pristop do teh skupin. Poleg tega bi poskrbeli, da bi bili dogodki dostopni širši množici obiskovalcev, kar bi izkazovali z izjavo o dostopnosti tako za starejše, osebe na invalidskih vozičkih, osebe $z$ drugimi oviranostmi itd.

\section{(vii) Promocija}

Promocija ali oglaševanje je eden od načinov privabljanja turistov na cilj ali dogodek. $\mathrm{Na}$ ta način lahko dogodek spodbudi ekoturiste, da obiščejo dogodek. Vsekakor je pomembno, da sama promocija poteka v skladu s trajnostnim razvojem. Spletno oglaševanje, osebna promocija in mobilno trženje so trajnostni načini, medtem ko jumbo plakati, izdelani iz plastike, da se ne zmočijo $v$ dežju in na prostem, niso nikakor trajnostni, saj po njihovi odstranitvi ostane ogromno odpadkov. Papirnati obrazci, kot so letaki, so bolj trajnostni, vendar niso najboljši način za promocijo. Najboljši način je zagotovo oglaševanje na družbenih omrežjih in glede na vpliv tehnologije lahko rečemo, da je ta način tudi najbolj vpliven. 
Sploh glede na situacijo s pandemijo covida-19 bi se trženje v največji možni meri preusmerilo skoraj izključno na spletne platforme, kot so družabna omrežja, različni forumi in portali ter osebna priporočila. Na ta način bi zmanjšali finančne stroške in ne bi prispevali k onesnaževanju narave na primer $z$ reklamnimi panoji ali plakati na stebrih, ki bi jih bilo treba pozneje odstraniti ali narediti iz dražjih težko razgradljivih materialov.

Predlagamo, da se ustvari aplikacijo, ki bi predstavljala pregled celotnega dogodka. Aplikacija bi bila zasnovana tako, da lahko obiskovalci spremljajo vse spremembe na dogodku, od vremenskih sprememb, pregleda lokacij, pregleda ponudnikov, ki sodelujejo na prireditvi, prevoznih linij (avtobusi, taksiji, kolesa, avtomobili) do parkiranja. Bistvo aplikacije je lažje upravljanje dogodka in obiska na dogodku.

Drugi predlog je, da se na samih dogodkih vzpostavi stojnico ali kaj podobnega, kjer se bo obiskovalce ozaveščalo o trajnosti. Tako bi se lahko udeležili 10-minutne predstavitve, nato pa sodelovali $\mathrm{v}$ nagradni igri ter prejeli trajnostne nagrade za spodbudo.

\subsection{Napotki za posamezno vrsto prireditve}

$\mathrm{V}$ tem poglavju smo najprej predstavili splošne trajnostne smernice za vse dogodke, ki jih lahko upoštevajo pri izvedbi. $\mathrm{V}$ nadaljevanju smo podrobno opredelili prireditve glede na vrsto prireditev. Po vsebini smo dogodke razdelili na kulturne (festivali, karnevali, verske prireditve, parade, spominske slovesnosti), poslovne/komercialne (sejmi, konference), umetnostne/zabavne (koncerti, predstave, razstave, podeljevanje nagrad), športne (profesionalna tekmovanja, mitingi, priprave) in rekreacijske (šport za zabavo, zabavne igre), izobraževalne/znanstvene (seminarji, delavnice, kongresi), državno-politične (inavguracije, obiski državnikov, zborovanja) in zasebne prireditve (obletnice, družinska praznovanja, sindikalne zabave) (Sikošek, 2010). 


\subsubsection{Kulturne prireditve}

- Zmanjšanje onesnaženosti zraka in ogljičnega odtisa

Predlagamo, da se za organizacijo kulturnih prireditev z namenom zmanjšanja onesnaženosti zraka in ogljičnega odtisa na okolje poskuša uporabljati čim manj dostavnih vozil, tovor pa združevati. Predlagamo, da se ob promociji dogodka promovira tudi prihod na prireditev z javnim prevozom oziroma s čim bolj trajnostnim prevozom. Tega pa se lahko lotijo tudi s kombiniranjem vstopnic, kjer lahko v vstopnico vključijo vstopnino na prireditev in vozovnico za javni ali organizirani prevoz.

\section{- Dostopnost in vključevanje}

Da bi bile prireditve bolj trajnostne, predlagamo, da se poskrbi tudi za vključenost gibalno, mentalno in drugače oviranih. Tako bi lahko za gluhe zagotovili tolmačenje $\mathrm{v}$ znakovni jezik ob glavnem dogajanju in za slepe napise $z$ Braillovo pisavo. Pri organizaciji prireditve naj imajo organizatorji $\mathrm{v}$ mislih tudi, da prireditev ostane ekonomsko dostopna za vse.

\section{- Ozaveščanje uporabnika o trajnostnem razvoju}

Predlagamo, da se na prireditvah pripravi razstava na temo trajnosti in varovanja okolja. Predlagamo tudi, da se morda pripravi krajše predavanje (ali predstavitev) pred začetkom glavnega dogajanja na temo trajnosti in varovanja okolja za vse obiskovalce prireditve.

- Uvedba vstopnic na prireditvah za skladnost z nosilnostjo okolja

Število obiskovalcev se na mnogih prireditvah iz leta v leto povečuje, zato na vseh prireditvah predlagamo uvedbo omejitve števila obiskovalcev. Predlagamo uvedbo vstopnic na vseh prireditvah, vendar pa te vstopnice ne bi bile le kos papirja, ampak priročen, uporaben izdelek, povezan s tematiko prireditve, katerega bi obiskovalci po koncu prireditve lahko odnesli domov. 
- Zmanjšanje oziroma nadomeščanje tiskanih in promocijskih materialov

Predlagamo, da se vsi tiskani promocijski materiali (letaki, zloženke, tiskana vabila) nadomestijo z e-verzijo. Vse tiskovine, ki jih ne morejo nadomestiti, organizatorji natisnejo na recikliran papir. Na prireditvenih stojnicah se delijo le vizitke z imenom, kontaktom in hiperpovezavo do spletne strani ponudnika.

- Pri prireditvi uporabljamo trajnostne ali biorazgradljive produkte in stremimo k trajnosti

Pri pogostitvah na vseh prireditvah se ne uporablja plastična embalaža in ostali pripomočki. $\mathrm{Na}$ prireditvenih stojnicah se lahko za embalažo uporabljajo le biorazgradljivi materiali ali materiali za večkratno uporabo (npr. papirnate ali platnene vrečke, steklenice ...).

- Doniranje ostankov hrane, sestavin

Predlagamo, da se vse sestavine in hrano, ki ostane po koncu prireditve in se še lahko uporabi $\mathrm{v}$ naslednjih dneh, donira lokalnim skupinam, ki pomagajo lokalnim prebivalcem, ki živijo $v$ pomanjkanju (na primer družine $z$ mlajšimi otroci z nižjim prihodkom, upokojencem, brezdomcem ...). Ostanke pa lahko namenijo eni od lokalnih kmetij, ki lahko z njimi nahrani svoje živali.

- Skrb za obiskovalce z različnimi intolerancami (vegani, vegetarijanci, laktozna intoleranca, celiakija)

Pri pogostitvi s hrano in pijačo morajo biti organizatorji pozorni tudi na osebe $\mathrm{z}$ raznimi intolerancami na hrano. Predlagamo, da pogostitev vsebuje tudi hrano, ki jo lahko zaužijejo ljudje z intoleranco.

- Uporaba ekoloških čistil

Za pripravo in pospravljanje stojnic in prireditvenega prostora predlagamo, da se uporabljajo ekološka čistila, ki ne škodujejo okolju (znak »eco label«). 
- Varčevanje z vodo na toaletah

Predlagamo, da se na vseh prireditvah uredijo toaletni prostori z označbami za obiskovalce. $\mathrm{Na}$ označbah naj bo prikazano, kako trajnostno uporabljati vodo in papir. Prav tako predlagamo označbo tipk za spuščanje vode $\mathrm{v}$ straniščni školjki posebej za malo in veliko potrebo, obenem pa predlagamo tudi umivalnike na senzorje, ki zaznavajo roke in na tak način ne točijo dodatne nepotrebne vode.

- Nakupovanje toaletnega papirja neposredno od proizvajalca v kartonasti embalaži

Toaletni papir (tudi papirnate brisače) že sam po sebi predstavlja ogromno odpadkov, ko pa zraven štejemo še plastično embalažo, v kateri ga kupimo v trgovini, to ustvari še več nepotrebnih odpadkov. Zato priporočamo, da se toaletni papir kupi od slovenskih ponudnikov. Na ta način bodo toaletni papir (tudi papirnate brisače) organizatorji dobili v kartonasti embalaži, ki jo lahko reciklirajo, najboljša pa bi bila ponovna uporaba ali dogovor s podjetjem, da kartonasto embalažo vrnejo in naslednjič v njej ponovno dostavijo papir.

- Papirnate brisače iz recikliranega papirja za brisanje rok

$\mathrm{Na}$ toaletah predlagamo za brisanje rok uporabo papirnatih brisač iz recikliranega papirja, saj na tak način zmanjšamo količino nastalih odpadkov, kajti brisačke že same po sebi predstavljajo ogromno količino odpadkov.

- Optimizacija družbenih medijev in tehnologije, ki temelji na aplikacijah, za komuniciranje $z$ udeleženci

Predlagamo, da se pred prireditvami pripravi aplikacija, s katero organizatorji komunicirajo z vsemi udeleženci. Prek teh aplikacij se udeležencem tudi sporoči, če pride do kakršnih koli sprememb glede začetka prireditve, lokacije prireditve ... Prav tako se prek družbenih omrežij prireditev promovira, na tak način skrbimo za trajnost in varujemo okolje. 
- Vpliv na lokalno skupnost

Pomembno je, da lokalno prebivalstvo podpira prireditve in se jih udeležuje. Predlagamo, da se na prireditve $v$ čim večji meri vključuje lokalne, manjše ponudnike, saj se jim tudi na tak način povečuje prepoznavnost. Predlagamo, da se del sredstev nameni za razvoj lokalnega okolja.

\subsubsection{Poslovno-komercialne prireditve}

- Zmanjšanje onesnaženosti zraka in ogljičnega odtisa

Predlagamo, da se za organizacijo poslovno-komercialnih prireditev z namenom zmanjšanja onesnaženosti zraka in ogljičnega odtisa na okolje poskuša uporabljati čim manj dostavnih vozil in združevati tovor. Predlagamo, da se ob promociji dogodka promovira tudi prihod na prireditev $z$ javnim prevozom oziroma s čim bolj trajnostnim prevozom. Tega pa se lahko lotijo tudi s kombiniranjem vstopnic, kjer lahko v vstopnico vključijo vstopnino na prireditev in vozovnico za javni ali organizirani prevoz.

\section{- Dostopnost in vključevanje}

Da bi bile prireditve bolj trajnostne, predlagamo, da se poskrbi tudi za vključenost gibalno in mentalno oviranih. Tako bi lahko za gluhe zagotovili tolmačenje $\mathrm{v}$ znakovni jezik ob glavnem dogajanju in za slepe napise z Braillovo pisavo. Pri organizaciji prireditve naj imajo organizatorji $\mathrm{v}$ mislih tudi, da prireditev ostane ekonomsko dostopna za vse.

- Uporabnost novozgrajenih prireditvenih prostorov

Vsi novozgrajeni prireditveni prostori se lahko namenijo za izvedbo več vrst prireditev (na primer ne le za poslovno-komercialne, ampak morda tudi za kulturne ali športne prireditve). Na tak način lahko novozgrajene prireditvene prostore uporabljajo čez vse leto, ne le $\mathrm{v}$ času sezone, kar predstavlja tudi dodaten vir zaslužka. 
- Ozaveščanje uporabnika o trajnostnem razvoju

Predlagamo, da se na prireditvah pripravi razstava na temo trajnosti in varovanja okolja. Predlagamo tudi, da se morda pripravi krajše predavanje (ali predstavitev) pred začetkom glavnega dogajanja na temo trajnosti in varovanja okolja za vse obiskovalce prireditve.

- Zmanjšanje oziroma nadomeščanje tiskanih materialov

Predlagamo, da se vsi tiskani promocijski materiali (letaki, zloženke, tiskana vabila) nadomestijo z e-verzijo. Vse tiskovine, ki se jih ne da nadomestiti, organizatorji natisnejo na recikliran papir. Na prireditvi se delijo le vizitke $z$ imenom, kontaktom in hiperpovezavo do spletne strani. Po navadi ob prihodu na te vrste prireditev obiskovalci dobijo mapo, polno papirnatih dokumentov in informatorjev, kar svetujemo, da nadomestijo z elektronsko verzijo - vsak, ki pride na dogodek, pri vhodu uporabi svoj USB-ključek, na katerega se mu vsa gradiva naložijo v elektronski obliki.

- Postrežba z vodo v steklenicah, z vrči in kozarci

Na poslovnih prireditvah se voda navadno postreže v plastenkah, ki se jih običajno po prireditvi zavrže. Zato predlagamo za postrežbo vode uporabo steklenic ali steklenih vrčev in steklenih kozarcev, saj se ti po koncu prireditve operejo in jih lahko ponovno uporabijo na naslednji prireditvi, s čimer se tudi zmanjša količina novih odpadkov.

\section{- Varčevanje z energijo}

Na poslovnih in komercialnih prireditvah se naj čim bolje izkoristi dnevna svetloba, zato predlagamo, da se te prireditve začnejo $\mathrm{v}$ dopoldanskem času. $\mathrm{Na}$ tak način varčujemo tudi z energijo - umetno osvetlitvijo prostora. Predlagamo tudi čim manjšo uporabo grelnih in hladilnih naprav. Ob koncu prireditve naj se na računalnikih in ostali tehnologiji aktivira »sleep mode« ali se le-ti popolnoma ugasnejo. 
- Doniranje ostankov hrane, sestavin

Vse sestavine in hrano, ki ostane po koncu prireditve in se še lahko uporabi v naslednjih dneh, se donira lokalnim skupinam, ki pomagajo lokalnim prebivalcem, ki živijo $\mathrm{v}$ pomanjkanju (na primer družine $\mathrm{z}$ mlajšimi otroki z nižjim prihodkom, upokojencem, brezdomcem ...).

- Skrb za obiskovalce z različnimi intolerancami (vegani, vegetarijanci, laktozna intoleranca, celiakija)

Pri pogostitvi s hrano in pijačo morajo biti organizatorji pozorni tudi na osebe $z$ raznimi intolerancami na hrano. Predlagamo, da pogostitev vsebuje tudi hrano, ki jo lahko zaužijejo ljudje z intoleranco.

\section{- Uporaba ekoloških čistil}

Za pripravo in pospravljanje prireditvenega prostora predlagamo, da se uporabljajo ekološka čistila, ki ne škodujejo okolju (znak »eco label«).

- Varčevanje z vodo na toaletah

Predlagamo, da se na vseh prireditvah uredijo toaletni prostori z označbami za obiskovalce. $\mathrm{Na}$ označbah naj bo prikazano, kako trajnostno uporabljati vodo in papir. Prav tako predlagamo označbo tipk za spuščanje vode $\mathrm{v}$ straniščni školjki posebej za malo in veliko potrebo, obenem pa predlagamo tudi umivalnike na senzorje, ki zaznavajo roke in na tak način ne točijo dodatne nepotrebne vode.

- Nakupovanje toaletnega papirja neposredno od proizvajalca $\mathrm{v}$ kartonasti embalaži

Toaletni papir (tudi papirnate brisače) že sam po sebi predstavlja ogromno odpadkov, ko pa zraven štejemo še plastično embalažo, v kateri ga kupimo v trgovini, to ustvari še več nepotrebnih odpadkov. Zato priporočamo, da se toaletni papir kupi od slovenskih ponudnikov. Na ta način bodo toaletni papir (tudi papirnate brisače) organizatorji dobili v kartonasti embalaži, ki jo lahko reciklirajo, najboljša pa 
bi bila ponovna uporaba ali dogovor s podjetjem, da kartonasto embalažo vrnejo in naslednjič v njej ponovno dostavijo papir.

\section{- Papirnate brisače za brisanje rok iz recikliranega papirja}

$\mathrm{Na}$ toaletah predlagamo za brisanje rok uporabo papirnatih brisač iz recikliranega papirja, saj na tak način zmanjšamo količino nastalih odpadkov, kajti brisačke že same po sebi predstavljajo ogromno količino odpadkov.

\section{- Vpliv na lokalno skupnost}

Pomembno je, da lokalno prebivalstvo podpira prireditve in se jih udeležuje. Predlagamo, da se na prireditve $\mathrm{v}$ čim večji meri vključuje lokalne, manjše ponudnike, saj se jim tudi na tak način povečuje prepoznavnost. Predlagamo, da se del sredstev nameni za razvoj lokalnega okolja.

\subsubsection{Umetniške/zabavne prireditve}

- Infrastruktura in lokacija

$\mathrm{V}$ to skupino prireditev se med drugim uvrščajo koncerti, predstave, razstave in podelitve nagrad. $\mathrm{V}$ primeru infrastrukture in lokacije je pomembno, da načrtujemo dogodek v obstoječih prostorih ali lokacijah, da se ne troši dodatnih virov energije. V obstoječih prostorih, ki so za to opremljeni, je mogoče organizirati postavitev nove razstave, muzeja, zabavnega dogodka, predstave ali koncerta. $\mathrm{V}$ to temo sodi tudi komunalna infrastruktura, kjer je ključna varčna raba vode.

- Naravno okolje

Naravno okolje prireditve ključno narekuje celoten proces organizacije umetniške/zabavne prireditve. $\mathrm{V}$ takem primeru je ključnega pomena minimalna raba oporečnih virov in izdelkov. Za tovrstne prireditve je pomembna uporaba recikliranega materiala brez plastike. Med predstavo, koncertom ali razstavo je pomembno prilagoditi glasnost zvočnikov in razsvetljavo, ki pri prekomerni uporabi škoduje okolju in naravi. Vsekakor je priporočljivo uporabljati sončno svetlobo čim več časa in kadar koli je to mogoče. 
- Mobilnost

Umetniški dogodek je zelo enostavno povezati z mobilnostjo, saj je uvedba hoje ali uporabe električnega avtobusa zelo enostavna. Onesnaževanje zraka škoduje naravi, zato je uporaba trajnostnih načinov prevoza na prireditev ali koncert izjemnega pomena. Uporaba koles je zanimiva možnost tudi pri trajnostni mobilnosti in je mogoča za vse obiskovalce, ki živijo v bližini lokacije. Zagotovo je najboljši trajnostni način sprehod do same prireditve.

\section{- Varčevanje z energijo}

Varčevanje z energijo je eden ključnih elementov načrtovanja umetniškega dogodka. Organizacija dogodka pri dnevni svetlobi je nujna. Namesto da bi koncert priredili ob osmih zvečer, ga lahko ob enih popoldne ali ob drugem delu dneva, ko sončna svetloba zadostuje za osvetlitev prostora. Seveda ne gre vedno le za svetlobo, včasih se na koncertih ali predstavah uporabljajo različni učinki, ki s sončno svetlobo niso mogoči. Vendar je ta segment enostavno rešljiv, če so nameščene sončne celice, ki zbirajo sončno energijo in tako zagotavljajo vir energije. $V$ tem segmentu priporočamo, da se za podrobnosti o možnosti pridobitve subvencije za sončno elektrarno obrnete na občino, mesto ali državo. Vsekakor je treba in v čim več primerih, če ne vedno, uporabljati energetsko varčne vire energije, ki ne onesnažujejo okolja.

\section{- Odpadki}

$\mathrm{Na}$ koncertih, promocijah, podelitvah nagrad ali drugih družabnih dogodkih je priporočljivo namesto plastičnih uporabiti steklene kozarce. $\mathrm{Na}$ ta način se zmanjšajo odpadki (nepotrebna plastična in nerazgradljiva embalaža). Plastične krožnike je mogoče nadomestiti s keramičnimi ali papirnatimi krožniki. Možna je tudi uporaba lesenega ali drugega biološko razgradljivega materiala. $\mathrm{Na}$ samem dogodku je treba vzpostaviti ustrezne koše za odpadke oziroma ekološke otoke za biološko razgradljive odpadke, plastiko, steklo in papir. To olajša ločevanje odpadkov. 
- Hrana in pijača

Na prireditvah, kot so koncerti, promocije, podelitve nagrad ali podobno, je zelo pogosto uživanje pijač in hrane. Vključitev organske lokalno pridelane hrane v prehrano je en način trajnostnega delovanja. Ta segment vključuje tudi uporabo steklovine za večkratno uporabo, keramike ali drugih materialov. Plastični kozarci, ki jih uporabljajo udeleženci koncerta, so eden glavnih onesnaževalcev na samem koncertu. Z uvedbo nakupa kozarca in njegovo uporabo ob kavciji ves večer, lahko veliko doprinesemo k zmanjšanju nepotrebnih odpadkov. Na koncertu oseba kupi kozarec, na koncu večera pa ga lahko vzame domov kot spominek na dogodek. Ob tako velikih dogodkih v velikem številu primerov ostane presežek hrane in pijače. Treba je vzpostaviti stik z organizacijami, ki prejemajo donacijo hrane, in po dogodku hrano odpeljati na to lokacijo. Vso hrano in pijačo, ki ostane in ni uporabna, je vsekakor pomembno reciklirati ali dostaviti na biološko razgradljiv kompost.

\section{- Družbena odgovornost}

Družbena odgovornost poslovanja vseh udeležencev dogodka je izredno pomembna. Organizatorji prireditev, prodajalci vstopnic, delavci in vse vpletene strani morajo delovati $\mathrm{v}$ skladu z odgovornim poslovanjem, da bo sam dogodek na koncu trajnosten. Vsak od udeležencev dogodka, ne glede na to, ali je imel majhen ali pomemben vpliv, bi moral spoštovati družbeno odgovorno poslovanje $\mathrm{v}$ skladu s smernicami trajnostnega razvoja.

\section{- Promocija}

Promocija koncerta, predstave ali razstave je pomemben element širjenja informacij in komuniciranja s potencialnimi obiskovalci. Pomembno je, da ravnamo po trajnostnih načelih. Kot smo že navedli, lahko promocijo koncerta, predstave ali razstave izvedemo prek spleta in se tako izognemo plastičnim plakatom. 


\subsection{4 Športne/rekreacijske prireditve}

- Infrastruktura in lokacija

Skupina športnih prireditev vključuje različna tekmovanja, prireditve, tekme, plesne predstave in podobno. Pri izbiri lokacije za športni dogodek je pomembno, da se izbere prizorišče, ki je namenjeno prav takšnemu dogodku, na primer športno dvorano ali zunanje športno igrišče. Tako ima to mesto že večino potrebne opreme za izvedbo različnih športnih prireditev. S tem se izognemo dodatnim stroškom zaradi prilagajanja lokacije.

\section{- Naravno okolje}

Naravno okolje je zelo pomembno upoštevati pri prireditvah na prostem. Pomembno je pametno uporabljati naravne vire in biti pozoren na minimalno onesnaževanje. Uporabljati je treba obnovljive vire energije, skrbeti za odstranjevanje odpadkov in prilagoditi glasnost na zvočnikih. Pozitivno je, da lahko takšni dogodki potekajo podnevi brez umetne svetlobe, sonca je dovolj. Na takih prireditvah se pogosto prodajajo prigrizki in pijače, zato je pomembno, da imajo na več mestih zabojnike za smeti.

\section{- Mobilnost}

Športni dogodki imajo zelo jasno izdelan program - čas trajanja. Zato hkrati prihaja in odhaja veliko število ljudi. Glede na to priporočamo organiziran prevoz z električnimi avtobusi. Na ta način je onesnaženje čim manjše. $Z$ avtobusom se lahko odpeljejo obiskovalci, ki živijo v bližini, in tisti, ki prihajajo iz oddaljenih krajev in so parkirali na skupnih parkiriščih. Brezplačen prevoz in natančen vozni red zagotavljata zadovoljstvo obiskovalcev pri uporabi te storitve.

\section{- Varčevanje z energijo}

Športne prireditve porabijo veliko energije. Od razsvetljave do ozvočenja. Vsekakor priporočamo prireditev na prostem pod sončno svetlobo. Če to ni mogoče, predlagamo uporabo energije iz sončnih kolektorjev in varčno rabo energije. Luči na senzor na stranišču so odličen primer, energija se porabi le, kadar je to potrebno. 


\section{- Odpadki}

Športni dogodki povzročajo veliko odpadkov. Priporočamo zamenjavo plastike s papirjem, kartonom in steklom. To velja za jedilni pribor in postrežbo pijače. $\mathrm{Na}$ ta način se uporabljajo samo razgradljivi materiali, ki ne škodujejo naravi. Pomembno je tudi, da koše za smeti postavite na vsa vidna mesta. Na koncu prireditve je pomembno, da organizatorji razvrščene odpadke dejansko odložijo na predvidenem mestu za nadaljnjo recikliranje.

- Hrana in pijača

Kot smo že omenili, je hrana in pijača vključena $v$ vse vrste prireditev. Zato je pomembno, da ta dejavnik čim bolj uskladimo s trajnostnim razvojem. Predlagamo prodajo hrane in pijače lokalnih prodajalcev. Dobrodošla je tudi uporaba ekološko pridelane hrane, ker na ta način podpiramo in spodbujamo to obliko pridelave. Hrana naj bo v kartonskih skledah ali krožnikih z lesenim jedilnim priborom, pijače pa iz steklenih kozarcev, ki bi jih po koncu prireditve oprali in ponovno uporabili.

\section{- Družbena odgovornost}

Družbena odgovornost je eden najpomembnejših dejavnikov za izvedbo uspešnega dogodka v skladu s trajnostnim razvojem. Vsi udeleženci se morajo držati pogojev in dogovora. Sem spadajo organizatorji, voditelji, prodajalci hrane in pijače, zaposleni, ki skrbijo za čiščenje, in drugi. Njihovo spoštovanje pravil vodi do tega, da se jih vsi obiskovalci držijo.

\section{- Promocija}

Promocija in oglaševanje je tisto, kar obiskovalce pripelje na dogodek. Da bi se izognili onesnaževanju okolja, priporočamo promocijo prek spletnih strani v obliki oglasov, objav v revijah in podobno. Poleg tega predlagamo oglase na ulicah v obliki pametnega zaslona, ki se polni s sončno energijo. S promocijo v digitalni obliki se pojav nepotrebnih odpadkov popolnoma zmanjša. 


\subsubsection{Izobraževalne/znanstvene prireditve}

Pri tej vrsti prireditev je zelo pomembno omeniti, da je skoraj vsako od prej naštetih smernic mogoče enostavno vključiti v vzpostavitev tovrstnega dogodka. Za vsako vrsto dogodka, vključno z izobraževalnimi in znanstvenimi prireditvami, veljajo več ali manj ista pravila ali smernice. Dodali smo še nekaj drugih poudarkov.

- Prilagoditev ciljni skupini

Glede na ciljne skupine, ki se udeležujejo izobraževalnih in znanstvenih prireditev, mora biti kakovost dogodka na visoki ravni in prilagojena ciljni skupini, katero naslavlja. Če so na primer udeleženci otroci, jim bo vsebina podana na slikovit način, s pomočjo lutk ali risanega filma oziroma s pomočjo prispodob. Po drugi strani pa bo način podajanja vsebine zagotovo bolj strokoven in zahteven za odrasle znanstvenike in raziskovalce.

- Trajanje dogodka

Pri prireditvi sta pomembna tudi dolžina trajanja dogodka in termin, $\mathrm{v}$ katerem poteka. Dolžina trajanja ne sme biti predolga niti prekratka - izbrati moramo zlato sredino glede na ciljno skupino, saj udeleženci cenijo svoj čas, ki ga namenijo kakovostnim vsebinam. Glede termina se moramo odločiti, ali gre za večdnevni dogodek, ali bo potekal konec tedna, med prazniki in podobno, glede na časovno razpoložljivost udeležencev. Predlagamo, da je za izobraževalni dogodek primeren čas trajanja dva dni za odrasle, za otroke pa en dan.

\subsubsection{Državne/politične prireditve}

Politične prireditve so tiste, ki imajo določen protokol; to pomeni, da imajo točno določen program, po katerem se prireditev odvija. Določeno je na primer, da bo na začetku prireditve govornik, sledi odprtje prireditve, ogled razstave, delavnice, kosilo, zabavni program in podobno. Celoten program je običajno zelo natančno določen tako vsebinsko kot časovno. Državno-politične prireditve načrtuje in vodi protokolna komisija. Smernice za protokolarne dogodke, na katere bi se osredotočili, so: udeležence spodbujamo, da prihajajo na dogodek z okolju prijaznimi prevozni sredstvi; na dogodku imamo postavljene koše za ločeno zbiranje odpadkov; 
spodbujamo uporabo kozarcev in krožnikov iz biorazgradljivega materiala; toaletne prostore uredimo tako, da so estetsko lepi in se lahko uporabljajo veliko let (pri zunanjih dogodkih kot premične plastične toaletne kabine); skladno z epidemiološko situacijo poskrbimo za razkužila za roke in maske; opozarjamo obiskovalce, da upoštevajo fizično razdaljo, omejimo število oseb, ki lahko sodelujejo znotraj prireditve (obiskovalce in udeležence).

\subsubsection{Zasebne prireditve}

Ko govorimo o zasebnih prireditvah, je njihova trajnostna naravnanost odvisna od posameznika oziroma skupine, ki jo organizira. Če je organizator trajnostno naravnan, bo poskrbel za biorazgradljive krožnike, pribor in kozarce. Svojim gostom bo postregel hrano lokalnega izvora. $V$ času epidemije je treba ozaveščati goste, da se ni priporočljivo družiti brez maske. Zasebna prireditev, ki je trajnostno naravnana, naj bi se odvijala v naravi, na svežemu zraku. Prostor bi bilo treba oskrbeti s koši za ločevanje odpadkov. Goste je treba spodbujati, da so na prireditvi aktivni, da se organizirajo skupinske igre na prostem, kot je odbojka, nogomet ali košarka. Izkoristiti je treba kreativnost in organizirati delavnice, na primer iskanje skritega zaklada $\mathrm{v}$ gozdu. Lahko se razdelijo po skupinah in tekmujejo $\mathrm{v}$ pripravi jedi iz sestavin, ki so jih našli v svoji okolici (gobe, med, gozdni sadeži ...). Goste bi povabili, da pridejo z okolju prijaznimi prevoznimi sredstvi. Lahko bi naredili akcijo zasajevanja novih dreves. Vsi bi bili povabljeni, da prinesejo vreče za spanje in bi spali zunaj, na prostem. Zvečer ne bi uporabljali elektrike, ampak bi zakurili taborni ogenj. Omejili bi predvajanje glasbe prek zvočnikov in raje spodbudili goste, da pojejo v skupini. Jutro po dogodku bi vse skupaj povabili, da počistijo smeti. 
PRIPOROČILA ZA ZELENE PRIREDITVE: PRIMER PRIREDITVE PRAZNIK KOZJANSKEGA JABOLKA 
Poglavlje 7

\title{
Priporočila za prireditev »Praznik kozjanskega jabolka«
}

\author{
LuKas Deu, Simon DorfFNer, IMELdA FELIĆ, LARA Fudurić, \\ Joško Glavina, Luka GošEK, Tena Gregorić, SARa Horvat, \\ Iva Jerotijević, Patricija Kelhar, Franjo Krapec, Katja Magdič, \\ Nikola Mahnić, Petar MilošEvić, Eva Pašalić, Janko Pelikan, \\ Marija Pristaš IN LOVRO VitKo
}

V nadaljevanju predstavljamo smernice, ki jih predlagamo za organizacijo prireditve Praznik kozjanskega jabolka 2021, da bi le-ta postala okoljsko bolj trajnostna.

\section{- Ozaveščanje o trajnostnem razvoju}

Na prireditvi Praznik kozjanskega jabolka 2021 naj se pripravi razstava na temo trajnosti in varovanja okolja (zraven razstave starih sort jabolk). Razstavo pripravi Kozjanski park in odprtje razstave poteka ob isti priložnosti kot odprtje razstave starih sort jabolk. S tem bi obiskovalce ozaveščali, kako pripomorejo k ohranjanju narave in zmanjševanju onesnaževanja okolja. 
- Ponudba novih dogodkov in vsebin

Kot vodilo za razvoj tega dogodka predlagamo oblikovanje bogatejše ponudbe in vsebine za otroke. Ta sklop smernic povezuje kulturo in otroke, ki se tega festivala tudi udeležujejo. Učenje in uvajanje otrok v kulturo in tradicijo je zelo pomemben dejavnik, ki spodbuja in dviguje kulturni turizem na višjo raven. Organizirajo naj se delavnice za otroke, ki naj se uporabljajo kot način za spoznavanje kulture in zgodovine tega območja. $\mathrm{Na}$ delavnicah predlagamo uporabo materialov, ki se reciklirajo, torej brez uporabe nerazgradljivih materialov. Možna je tudi organizacija turnirjev za otroke. Za otroke bi lahko organizirali tudi tombolo, kateri se lahko pridružijo z vplačilom $5 €$. Nagrade bi bili razni proizvodi iz jabolk, album s slikami in opisom vseh sort jabolk ter razni spominki v duhu festivala. Glavna nagrada na tomboli pa bi bila sadika jablane $\mathrm{v}$ loncu s posvetilom nagrajencu. Nagrajenec bi moral skrbeti za to jablano in naslednje leto poročati o njenem napredku. Za odrasle pa bi organizirali tečaj vzgajanja jablan od semena do ploda, cena tečaja bi bila $5 €$ na osebo.

- Omejitev števila obiskovalcev in uvedba trajnostnih vstopnic na prireditvah

Število obiskovalcev sejma je $\mathrm{v}$ zadnjih letih naraščalo in menimo, da je preseglo mejo, ki jo okolje zdrži. Za maksimalno ohranitev narave predlagamo omejitev in nadzor nad številom gostov ob obisku sadovnjakov, torej na prireditvi »Obisk kozjanskih sadovnjakov«, s ciljem ohranjanja sadovnjakov in avtohtonih sort. Na ta način bi zmanjšali količino odpadkov in spremljali vedenje obiskovalcev. To bi izvedli z uvedbo vstopnic na dogodek, ki ne bi bile le kos papirja, ampak uporaben izdelek, ki ostane obiskovalcem za domov (predlagamo vrečko iz blaga z logotipom dogodka). Vrečka naj bo narejena iz trajnostnih materialov in v lokalnem okolju. Alternativa za vrečko je pletena košarica (prav tako narejena v lokalnem okolju iz trajnostnih in lokalnih materialov). Z vrečko ali košarico si obiskovalci pomagajo nositi izdelke, ki jih kupijo na stojnicah, hkrati pa jim ostane kot spomin za poznejšo rabo, s katero bodo hkrati delali tudi promocijo Praznika kozjanskega jabolka. Število obiskovalcev sejma se omeji na 10.000, vstopnica (v obliki vrečke iz blaga ali košarice) stane $5 €$. Cena ni visoka, saj je bil sejem v preteklih letih brezplačen. 
- Lokalna ponudba in tradicija

Pri gastronomski ponudbi bi morali organizatorji poskrbeti, da bi na festivalu ponujali samo lokalno pridelano hrano, ki naj bo v čim večji meri rastlinskega izvora. Že pred samim festivalom bi lahko na bolj obiskanih točkah v večjih okoliških mestih postavili stojnice, kjer bi vabili obiskovalce na dogodek z manjšo brezplačno degustacijo lokalnih pridelkov (na primer jabolčna pita, sok, kaša ...), hkrati pa tudi ponudili pridelke $\mathrm{v}$ nakup.

V sam dogodek je pomembno vključiti tradicijo. Predlagamo, da se tradicijo prikaže s samimi nastopi, ko se izklopijo zvočniki in prisluhnemo živi glasbi. Oblačila tistih, ki predstavljajo tradicijo, naj bodo trajna in uporabljena vsako leto, da se izognemo nakupu novega in odmetavanju starega. Treba je spodbujati tradicionalne obrti in jim omogočiti, da predstavijo svoje izdelke.

- Združevanje dostavnih vozil (stojnice, ponudniki ...)

Predlagamo, da se dostava raznih stojnic in rekvizitov, ki se uporabljajo v sklopu prireditve, izvede s čim manj dostavnimi vozili. Ponudnike bi lahko spodbujali, da svoje produkte, izdelke in promocijski material na kraj prireditve dostavijo s skupnimi prevozi.

- Organizacija javnega prevoza na prireditev iz večjih okoliških mest in manjših krajev

Ker lokacija prireditve ni najbolje dostopna $\mathrm{z}$ javnim prevozom, predlagamo, da se organizira poseben javni prevoz iz večjih okoliških mest, kot so Celje, Krško in Brežice, na poti do prireditve pa imajo postanke tudi na vmesnih lokacijah (Šmarje pri Jelšah, Podčetrtek, Senovo, Bizeljsko ...). Iz Brežic bi se za organizacijo prevoza dogovorili z Integral BreBus, iz Krškega s podjetjem Mirttours ali Avtobusni prevozi Božidar Bračun, iz Sevnice s podjetjem Novak bus ter iz Celja s podjetjem Nomago. Za to vrsto prevoza poskusimo pridobiti sponzorja. Vse ostale obiskovalce ter lokalno prebivalstvo bi bilo treba spodbujati, da na splošno uporabljajo okolju prijazna prevozna sredstva. Urediti je treba tudi parkirišča zunaj središča dogajanja prireditve. 
- Vpliv na okolje

Znano je, da močna svetloba in glasen zvok negativno vplivata na ptice in druge živali. Zaradi tega predlagamo prilagoditev svetlosti in glasnosti dogodka. To je eden od načinov, kako zaščititi živali in jih ne motiti.

- Pri prireditvi uporabljamo trajnostne ali biorazgradljive materiale

Pri pogostitvah na vseh dogodkih v sklopu Praznika kozjanskega jabolka (Kuhinja na gradu Podsreda, sejem na trgu Podsreda) ne uporabljamo plastične embalaže in pripomočkov (ni plastičnega pribora, kozarcev, krožnikov, ampak so namesto njih biorazgradljivi ali za večkratno uporabo). Predlagamo pokušino jabolčnega soka iz steklenih kozarcev. Delovalo bi tako, da obiskovalec za uporabo kozarca plača simbolični znesek, ki ga dobi nazaj po dogodku. Kozarce operemo, razkužimo in ponovno uporabimo. Tako zmanjšamo količino odpadkov (plastične kozarce) ter količino vode in detergentov, ker kozarce operemo šele ob koncu dneva. Na ta način se poleg odpadkov zmanjša tudi pretirana poraba vode. Ponudili bi tudi možnost nakupa kozarca ali jedilnega pribora z logotipom dogodka, delovalo bi enako, kot pri najemu steklenih, le da bi obiskovalec obdržal kupljeno. Obiskovalci bi imeli pravico do neomejene porabe pijač in pravico do ene jedi.

Pakiranja na stojnicah na sejmu so lahko izključno iz biorazgradljivih materialov (papirnate vrečke, steklenice ipd.). Tako bi lokalne jabolka in hruške prodajali v papirnatih vrečkah ali lesenih košarah. Papirnate vrečke so biorazgradljive in ne škodujejo okolju. Lesene košare lahko obiskovalcu ostanejo za spomin, lokalni ponudnik pa zasluži več. To popolnoma preprečuje uporabo plastike, ki je izredno škodljiva za naravo. Razen za jabolka in hruške bi to veljalo za vse spominke in izdelke, ki se prodajajo na sejmu.

- Uporaba ekoloških čistil (čiščenje šotora, stojnic)

Za pripravo in pospravljanje stojnic, prireditvenega prostora in prostora, kjer se odvijajo dejavnosti v zvezi s Praznikom kozjanskega jabolka, predlagamo, da se uporabljajo ekološka čistila, ki ne škodujejo okolju (znak »eco label«). 
- Ureditev javnih toaletnih prostorov, ki varčujejo z vodo

Glede na izkušnje članov naše ekipe smo ugotovili, da na prireditvi nikjer ni javnih toaletnih prostorov. Predlagamo, da se le-ta uredijo in se opremijo z označbami, ki obiskovalce opozarjajo na trajnostno uporabo vode in papirja, imajo male in velike tipke za spuščanje vode $v$ straniščno školjko in umivalnike s senzorjem, ki zaznavajo roke in tako ne točijo nepotrebne vode, ter luči na senzor.

- Nakupovanje toaletnega papirja in papirnatih brisačk v kartonasti embalaži, neposredno od proizvajalca

Toaletni papir in papirnate brisače predstavljajo ogromno odpadkov, ko pa zraven štejemo še plastično embalažo, $\mathrm{v}$ kateri jih kupimo $\mathrm{v}$ trgovini, to ustvari še več nepotrebnih odpadkov. Zato priporočamo, da se le-ti kupijo od slovenskih ponudnikov. Najbližji, ki smo ga našli, je podjetje Melian d.o.o. s Teharja. Na ta način bodo toaletni papir in papirnate brisače dobili v kartonasti embalaži, ki jo lahko reciklirajo, najboljša pa bi bila ponovna uporaba ali dogovor s podjetjem, da kartonasto embalažo vrnejo in naslednjič v njej ponovno dobijo papir.

- Dostopna prireditev

Naslednje vodilo za razvoj trajnosti festivala je zagotovo dostopni turizem. Glede na to, da je Praznik kozjanskega jabolka kulturni dogodek, je vsekakor ključno poskrbeti za invalide oziroma ljudi s posebnimi potrebami. V tem primeru lahko poskrbimo za organizirano vodenje invalidov po »Pohodu med sadovnjaki«. Tudi ta dogodek je del samega festivala, vendar za zdaj ni organiziranih navodil za invalide oziroma ljudi $z$ drugimi oblikami invalidnosti. Menimo, da je mobilnost pomembna in je tesno povezana $z$ dostopnim turizmom, ki je tesno povezan tudi s trajnostnim turizmom. Iz tega razloga predstavljamo primer uvedbe organiziranega vodenja oseb na invalidskih vozičkih, slepih in slabovidnih, da tudi oni izkusijo prireditev in se ne čutijo zapostavljeni. 
- Družbeno odgovorno delovanje lokalne skupnosti

Med kakovostne smernice bi lahko šteli uvedbo tehnologije, ki bi odstranjevala ogljikov dioksid iz ozračja, uporabo obnovljivih virov in na splošno izboljšano ekološko učinkovitost. Upravljanje s podnebno trajnostjo je še posebej pomembno za sama jabolka. Če ne skrbimo za podnebje, ne bo kakovostnih jabolk, ki so osnova za Praznik kozjanskega jabolka. Tako se moramo pravočasno pripraviti na podnebne spremembe, ki se bodo dogajale $\mathrm{v}$ prihodnosti. S tem bomo zmanjšali škodo, ki bi nastala zaradi podnebnih sprememb. Poiskati moramo rešitve za morebitne poplave z gradnjo protipoplavnih nasipov in vodnih zbiralnikov; proti suši bomo sadovnjake oskrbeti s sistemom kapljičnega namakanja; v primeru zelo mrzlih zim ali neviht $\mathrm{s}$ točo bi sadovnjake zaščitili z mrežami za zaščito dreves ali pa bi naredili ograje okoli sadovnjakov oziroma rastlinjakov.

- Zmanjšanje oziroma nadomeščanje tiskanih materialov

Tiskano promocijo Praznika kozjanskega jabolka nadomestimo z e-verzijo (e-verzije povabil/urnikov/oglaševanja, pobiranje elektronskih naslovov za pošiljanje). $\mathrm{Na}$ sejmu razstavljavci namesto tiskovin delijo le vizitke s povezavo do spletne strani. Tiskovine, ki jih ne moremo nadomestiti, natisnemo na recikliran papir. Oglaševanje izvajamo predvsem $\mathrm{v}$ digitalni obliki prek družbenih omrežij in portalov.

- Prilagajanje termina izvedbe

Praznik kozjanskega jabolka poteka meseca oktobra, ko veliko grožnjo predstavlja dež. Mislimo, da je vremenska napoved nekaj, na kaj ne moremo vplivati, moramo se ji le prilagoditi in imeti pripravljen načrt B - kaj narediti v primeru slabega vremena. Ena od smernic je, da imamo ekipo, ki redno spremlja in analizira vremenske napovedi pred prireditvijo. V primeru slabega vremena sta možni rešitvi, da se datum prireditve premakne za en teden oziroma program skrajšamo na dogodke, ki se lahko odvijajo v zaprtem objektu. Kulturni program, delavnice, razstave, zabavni program itd. bi se odvijali na gradu Podsreda, v Slovensko-bavarski hiši in Domu krajanov. V primeru slabega vremena bi oblikovali alternativna doživetja in lokacije za njihovo izvajanje. Sejem regionalnih produktov bi lahko postavili pod šotore. Gosti bi bili obveščeni in informirani o vseh morebitnih spremembah oziroma novicah, ki bi jih našli v aplikaciji. 
- Izvedba v času epidemije

V času epidemije predlagamo, da se Praznik kozjanskega jabolka v največji meri preseli na splet ter se tako odvija brez fizičnega kontakta. Če poteka na lokaciji in v živo, naj se v največji možni meri upošteva trenutno veljavne predpise in priporočila stroke. 
PRIPOROČILA ZA ZELENE PRIREDITVE: PRIMER PRIREDITVE PRAZNIK KOZJANSKEGA JABOLKA 


\section{Poglavlje 8 \\ Zaključek}

BARBARA PAVLAKOVIČ

Prireditve kot posebna vrsta turističnih znamenitosti so pomemben del turistične ponudbe destinacije. V monografiji smo predstavili njihovo teoretično ozadje in definicije ter spoznali, kakšne so njihove lastnosti. Še posebej smo izpostavili njihov potencial za trajnostno naravnanost in s tem spoštovanje odgovornega pristopa $\mathrm{k}$ turizmu. Osredotočili smo se na podeželske destinacije in možnosti, ki jih lahko zasledujemo na takih destinacijah. Kot zelo pomembne smo omenili gastronomske prireditve, ki lahko uporabijo model znamčenja ponudbe s kolektivno blagovno znamko (KBZ) po modelu »Izvorno slovensko«.

Teoretično znanje smo prenesli tudi na konkretni primer destinacije, in sicer na destinacijo Podčetrtek, Bistrica ob Sotli in Kozje. Samo področje in njegovo ponudbo je opisala Mojca Bračun iz lokalne turistične organizacije Turizem Podčetrtek, Bistrica ob Sotli in Kozje GIZ. Znotraj destinacije pa smo spoznali posebno območje, in sicer zavarovani park - Kozjanski regijski park. Opis območja in prireditve Praznik kozjanskega jabolka, ki je ime parka ponesla v svet, je pripravila mag. Valerija Slemenšek, naravovarstvena svetnica iz Javnega zavoda Kozjanski park. 
Prav prireditev Praznik kozjanskega jabolka je bila osnovno vodilo pri raziskovalnem delu študentov, ki so pripravili akcijski načrt za razvoj praznika $\mathrm{v}$ prihodnjih petih letih. Hkrati pa so podali tudi ključne smernice, ki jih mora celotna prireditev upoštevati, če želi biti trajnostna. Te smernice bi lahko povzeli v nekaj ključnih točk:

- ozaveščanje o trajnostnem razvoju;

- ponudba novih dogodkov in vsebin;

- omejitev števila obiskovalcev in uvedba trajnostnih vstopnic na prireditvah;

- lokalna ponudba in tradicija;

- združevanje dostavnih vozil (stojnice, ponudniki ...);

- organizacija javnega prevoza na prireditev iz večjih okoliških mest in manjših krajev;

- vpliv na okolje (hrup, osvetlitev, odpadki);

- pri prireditvi uporabljamo trajnostne ali biorazgradljive materiale;

- uporaba ekoloških čistil (čiščenje šotora, stojnic);

- ureditev javnih toaletnih prostorov, ki varčujejo z vodo;

- nakupovanje potrošnega materiala $\mathrm{v}$ kartonasti embalaži, neposredno od proizvajalca;

- dostopna prireditev;

- družbeno odgovorno delovanje lokalne skupnosti;

- zmanjšanje oziroma nadomeščanje tiskanih materialov;

- prilagajanje termina izvedbe;

- izvedba v času epidemije.

Praznik kozjanskega jabolka zagotovo že zdaj upošteva marsikatero od teh smernic, vendar moramo pri tem paziti, da se tako ravnanje ohrani tudi v prihodnosti. Po drugi strani pa je lahko Praznik kozjanskega jabolka zgled ostalim prireditvam tako na destinaciji Podčetrtek, Bistrica ob Sotli in Kozje kot drugje. Prireditve so lahko trajnostne, če sledijo osnovnim usmeritvam trajnostnega delovanja. In morda več trajnostnih prireditev skupaj spodbudi Slovensko turistično organizacijo, da $\mathrm{v}$ prihodnosti oblikuje in podeli znak »Slovenia Green Event« znotraj Zelene sheme slovenskega turizma. Verjamemo, da je lahko prav Praznik kozjanskega jabolka prvi prejemnik tega znaka. 


\section{Literatura in viri}

Allen, J., O’Toole, W., McDonnell, I. in Harris, R. (2011). Festival and Special Events Management (5. izdaja). Milton: John Wiley and Sons.

Arctur d.o.o. (2019). Tourism 4.0 initiative. Pridobljeno iz https://tourism4-0.org/, 26. 4. 2021.

Bogataj, J. (2019). Gastronomic Tourism: An opportunity to discover the diversity of local and regional cultures. V S. K. Dixit (ur.), The Routledge Handbook of Gastronomic Tourism, (str. 55-61). New York: Routledge.

Bojnec, Š. in Korpar, K. (2005). Vino in turizem v Ljutomersko-ormoških goricah. 3. konferenca DAES »Slovenija v EU - iz:ivi za kmetijstvo, živilstvo in podeřeljer. Moravske Toplice, 10.-11. 11. 2005, str. 191-201.

Coban, O. (2016). Event Tourism. V C. Avcikurt, M. S. Dinu, N. Hacioğlu, R. Efe, A. Soykan in N. Tetik (ur.), Global Issues and Trends in Tourism, (str. 459-469). Sofia: St. Kliment Ohridski University Press.

Collins, A. in Cooper, C. (2017). Measuring and managing the environmental impact of festivals: the contribution of the Ecological Footprint. Journal of Sustainable Tourism, 25(1), 148-162.

Demago (2020). Demago print. Pridobljeno iz https://www.demago.si/, 4. 12. 2020.

Društvo Ekologi brez meja (2016). Kaj je $Z W$ prireditev. Pridobljeno iz https://ebm.si/zw/turizem/prireditve/kaj-je-zw-prireditev/, 12. 5. 2021.

Edelheim, J. R. (2015). Tourist attractions: from object to narrative. Bristol; Buffalo; Toronto: Channel View Publications.

European Commission (b.d.). European Capitals of Smart Tourism. Pridobljeno iz https:/ / smart-tourismcapital.ec.europa.eu/index_en, 26. 4. 2021.

Getz, D. (2005). Event management and event tourism (2. izdaja). New York: Cognizant.

Getz, D. (2008). Event tourism: Definition, evolution, and research. Tourism Management, 29, 403-428.

Getz D. (2014). Festival and event, tourism. V J. Jafari in H. Xiao (ur.), Encyclopedia of Tourism. Springer, Cham. DOI: 10.1007/978-3-319-01669-6_84-1.

Getz, D. in Page, S. J. (2016). Progress and prospects for event tourism research. Tourism Management, 52, 593-631.

Goeldner, C. R. in Ritchie, J. R. B. (2003). Tourism: Principles, Practices, Pbilosophies. Hoboken (N. J.): Wiley. 
Graviart d. o. o. (2018). Kelih za vino. Pridobljeno iz http://www.graviart.si/izdelek/kelih-za-vino/, 7. 12. 2020.

Hall, C. M. (1989). The Definition and Analysis of Hallmark Tourist Events. Geography of Tourism and Recreation; GeoJournal, 19(3), 263-268.

Hall, C. M. in Sharples, L. (2008). Food and Wine Festivals and Events Around the World: Development, Management and Markets. Oxford: Butterworth-Heinemann.

Hall, C. M., Sharples, L., Mitchell, R., Mascionis, N. in Cambourne, B. (2003). Food Tourism Around the World: Development, Management and Markets. Abingdon: Routledge.

Holloway, J. C. in Humphreys, C. (2016). The business of tourism. Harlow [etc.]: Pearson Education.

ISO (b. d.). ISO 20121 sustainable events. Pridobljeno iz https://www.iso.org/iso-20121-sustainableevents.html, 12. 5. 2021.

Javni zavod Kozjanski Park (2012). Korjanski Park. Pridobljeno iz https://kozjanski-park.si/, 26. 5. 2021.

Lane B. in Kastenholz, E. (2018). Rural Tourism: New Concepts, New Research, New Practice. Abingdon: Routledge.

Lešnik Štuhec, T. (2021). Podě̌llje in razuoj gastronomije v Sloveniji: Teritorialne kolektivne blagovne znamke po modelu 'žvorno slovensko'v letu 2020. Maribor: Univerzitetna založba.

Messe Berlin (2020). ITB Berlin. Pridobljeno iz https://www.itb-berlin.com/de/, 4. 12. 2020.

Mestna občina Ljubljana (2015). Priročnik za organizacijo dogodkov po načelih trajnostnega razuoja. Pridobljeno iz https://www.ljubljana.si/assets/Razpisi/Prirocnik-za-organizacijo-dogodkov-po-nacelihtrajnostnega-razvoja.pdf, 27. 11. 2020.

Moja Košarica (b. d.). Papirnate NOSILNE vrečke z PLETENIM ROČAJEM 18×8×22. Pridobljeno iz http://vreckenet.moja-kosarica.si/si/izdelek/269/papirnate-nosilne-vrecke-z-pletenimrocajem-18x8x22/, 4. 12. 2020.

MORPC, EPA in SWACO (2014). Sustainable Events: Ideas for Incorporating Environmentally Friendly Practices into Meetings and Events. Columbus: EPA.

Morrison, M. A. (2019). Marketing and Managing Tourism Destinations. London; New York: Routledge.

Moscardo, G. (2007). Analyzing the Role of Festivals and Events in Regional Development. Event Management, 11(1-2), 23-32.

Multilingual (2013). Multilingual, vaš prevajalski partner. Pridobljeno iz https://www.multilingual.si/sl, 4. 12. 2020.

Občina Bistrica ob Sotli (2021). Dobrodošli v občini Bistrica ob Sotli. Pridobljeno iz http://www.bistricaobsotli.si/, 26. 5. 2021.

Občina Kozje (2021). Občina Kozjje. Pridobljeno iz https://www.kozje.si/, 26. 5. 2021.

Občina Podčetrtek (2017). Občina Podčetrtek. Pridobljeno iz http://podcetrtek.eu/, 26. 5. 2021.

O'Sullivan, D. in Jackson, M. (2002). Festival Tourism: A Contributor to Sustainable Local Development? Journal Of Sustainable Tourism, 10(4), 325-342.

Outdooractive (b. d.). Outdooractive. Pridobljeno iz https://www.outdooractive.com/en/, 26. 4. 2021.

Page, S. J. in Connell, J. (2014). Tourism: a modern synthesis. Andover: Cengage Learning.

Quick, L. (2020). Managing events. Real challenges. Real outcomes. London: Sage Publications.

Rdeča oranžna d. o. o. (2020). Facebook in Instagram marketing. Pridobljeno iz https://www.martinkorosec.com/e-tecaji/tecaji/facebook-in-instagram-marketing/, 7. 12. 2020.

Ritchie, J. R. B., in Crouch, G. I. (2003). The competitive destination: A sustainable tourism perspective. NewYork, NY: Cabi.

Sikošek, M. (2010). Management prireditev: Organizacija študentskih prireditev. Koper: Fakulteta za management.

Skoultsos, S. in Tsartas, P. (2009). Event tourism: Statements and questions about its impacts on rural areas. Tourismos, 4, 293-310.

SLAK d.o.o. (b. d.). Video produkcija Digital studio. Pridobljeno iz https://www.digitalstudio.si/, 4. 12. 2020.

Slovenska turistična organizacija (2017). Operativni naǐrt tř̌enja kulturnega turizma Slovenije 2018-2020 (ONKULT). Ljubljana: Slovenska turistična organizacija. 
Slovenska turistična organizacija (2018). Okusiti Slovenijo: Akcijski načrt razvoja in trženja gastronomskega turizma 2019-2023. Pridobljeno iz https://www.slovenia.info/uploads/gastronomija_b2b/ang_slo_lowres.pdf, 26. 4. 2021.

Slovenska turistična organizacija (2019). EDEN 2019: Zmagovalka na temo »Turizem dobrega počutja«je Poď̌etrtek. Pridobljeno iz https://www.slovenia.info/sl/novinarsko-sredisce/sporocila-zajavnost/9885-eden-2019-zmagovalka-na-temo-turizem-dobrega-pocutja-je-podcetrtek, 26. 4. 2021.

Slovenska turistična organizacija (2021a). Zelena shema slovenskega turizma. Pridobljeno iz https://www.slovenia.info/sl/poslovne-strani/zelena-shema-slovenskega-turizma, 26. 4. 2021.

Slovenska turistična organizacija (2021b). Podčetrtek. Pridobljeno iz https://www.slovenia.info/en/places-to-go/regions/thermal-pannonianslovenia/podcetrtek, 26. 5. 2021.

Slovenska turistična organizacija in Ministrstvo za gospodarski razvoj in tehnologijo (2018). Okusiti Slovenijo; Taste Slovenia, Kandidatura Slovenije za Evropsko gastronomsko regijo 2021. Pridobljeno iz https://www.slovenia.info/uploads/publikacije/taste_slovenia/okusiti-slovenijo.pdf, 26. 4. 2021.

Spar Slovenija trgovsko podjetje d.o.o. (b. d.). Spar online. Pridobljeno iz https://www.spar.si/online/welcome/, 4. 12. 2020.

Styria digital marketplaces d.o.o. (2020). Usmerjevalne ograje. Pridobljeno iz https://www.bolha.com/ostala-glasbena-oprema/usmerjevalne-ograje-oglas-522584, 4. 12. 2020.

Svet Evrope (2013). Industrial heritage and agri/ rural tourism in Europe. Directorate - general for internal policies policy department B: structural and cohesion policies. Pridobljeno iz https://www.europarl.europa.eu/RegData/etudes/etudes/join/2013/495840/IPOLTRAN_ET(2013)495840_EN.pdf, 26. 4. 2021.

Swarbrooke, J. (2002). Development and management of visitor attractions (2. izdaja). Oxford: ButterworthHeinemann.

The international centre (b. d.). Sustainable Event Guide for the socially minded planner. Mississauga: The international centre.

Turizem Podčetrtek, Bistrica ob Sotli in Kozje GIZ (b. d.). Visit Poď́etrtek, Bistrica ob Sotli in Kozjje. Pridobljeno iz https://www.visitpodcetrtek.com/sl, 26. 5. 2021.

United Nations Environment Programme (2012). Sustainable events guide. Give your large event a small footprint. Pariz: UNEP.

UnitPAC (2020). Zabojckei za sadje in zelenjavo (5 velikosti, lepljeni - PALETNA dostava). Pridobljeno iz https://www.unitpac.si/zabojcki-za-sadje-in-zelenjavo\#, 4. 12. 2020.

Van der Wagen, L. in White, L. (2010). Events Management: For tourism, cultural, business and sporting events (4. izdaja). Frenchs Forest: Pearson Australia.

Vodeb, K. (2018). Turistične atrakcije. Koper: Založba Univerze na Primorskem.

World Tourism Organization and Basque Culinary Center (2019). Guidelines for the Development of Gastronomy Tourism. Madrid: UNWTO. 


\title{
Recenzija monografije
}

\author{
IZR. PROF. DR. MARKO KOŠČAK
}

Že kar ustaljena praksa je, da Fakulteta za turizem v Brežicah s svojim študenti organizira terensko delo, ki je ena najbolj učinkovitih oblik pedagoškega procesa, pri kateri študenti spoznavajo izzive in smernice razvoja trajnostnega turizma. Pričujoča monografija oziroma projekt, v okviru katerega je nastala, se je osredotočal na pomen in vlogo trajnostnih prireditev. Destinacija Podčetrtek, Bistrica ob Sotli in Kozje je poznana po svojih odmevnih prireditvah, kot so npr. Praznik kozjanskega jabolka, Festival vina in čokolade, Koza zmaj itd. Izziv za mentorici in študente 3. letnika univerzitetnega programa Fakultete za turizem je bil pripraviti usmeritve za izvedbo trajnostnih prireditev $\mathrm{v}$ destinaciji. Tako se monografija $\mathrm{z}$ naslovom »Priporočila za zelene prireditve: primer prireditve Praznik kozjanskega jabolka«, osredotoča prav na to prireditev, vendar pa poleg tega ponuja priporočila in vsebino, ki se jo lahko uporabi ter prilagodi za katero koli drugo prireditev, ki želi slediti smernicam trajnostnega delovanja. Prepričani smo, da se bodo prireditve vrnile v »normalno obliko izvedbe« in se ponovno odvijale »v živo«. Takrat bo še posebej smiselno slediti smernicam za trajnostne prireditve, ki ne svetujejo samo o tem, kako varovati naravo, ampak tudi zdravje in dobro počutje samih udeležencev prireditve. To pa je osnovno vodilo vseh organizatorjev prireditev. 
Poleg obeh urednic v monografiji s svojimi prispevki sodeluje še 18 študentov, soavtorjev, ki jim je žal načrtovano izvedbo terenskega dela »v živo in na terenu«, tako kot je bilo sicer zamišljeno, preprečila pandemija COVID-19. Zato je bilo treba načrte prilagoditi. Posledično je bila izvedba projekta prilagojena in terenske vaje so se izvedle v obliki spletne okrogle mize s predstavniki destinacije, kjer so študenti spoznali posamezne organizacije in ponudnike. Pomemben del dogodka je bila tudi razprava, saj so študenti lahko postavljali vprašanja in pridobili pomembne informacije za svoje delo. Drug način pridobivanja podatkov je bila raziskava obstoječega gradiva o destinaciji in festivalu. Tako so raziskovalci uporabili dostopno literaturo, pregledali spletne strani in družbena omrežja, predvsem pa si ogledali videoposnetke festivala iz preteklih let. $\mathrm{Na}$ ta način so lahko dobili vsaj približni občutek, kako je prireditev potekala ter kakšno je bilo vzdušje na festivalu v "normalnih razmerah«. Menimo, da to nikakor ne zmanjšuje kvalitete opravljenega dela, saj se mora raziskovalec prilagoditi danim razmeram, ki tudi v normalnih okoliščinah niso vedno optimalne.

Monografija obsega 73 strani, skupaj z referencami, ki jih je 60. V monografiji je 8 tabel in 20 slik, nekaj od teh je avtorskih, nekaj pa iz arhiva Kozjanskega parka. V prvem poglavju je doc. dr. Tanja Lešnik Štuhec predstavila zeleno pametno podeželsko destinacijo s certificiranimi gastronomskimi prireditvami po modelu »Izvorno slovensko«. Turizem se nahaja v zelo zahtevnem času in trenutku svojega delovanja. Pandemija virusa COVID-19 je obrnila mnoge pretekle trende popolnoma na glavo in ta trenutek še ni popolnoma jasno, kako se bo turizem soočil in spoprijel z novimi izzivi. Dejstvo pa je, da bodo zelene in pametne podeželske prakse in destinacije, ki jih bodo le-te znale in bile sposobne ponuditi, verjetno pogostejši cilj obiska turistov. Zadnje raziskave v Evropi vezane na izkušnje ukrepov epidemije virusa Covida-19 kažejo, da obiskovalci iščejo destinacije, ki lahko ponudijo razpršeno, varno, poglobljeno, pristno, zeleno, vključujoče, izkustveno ... torej, doživljati tako znana, od masovnega obiska odmaknjena območja, kakor tudi njim še neznana območja in znamenitosti. Avtorica izpostavlja tudi pomen kolektivne blagovne znamke, ki je pomembno orodje razvoja podeželja in $\mathrm{v}$ verige povezanih ponudnikov. Ti zagotavljajo celovito in visokokakovostno gastronomsko ter z njo povezano ponudbo »od vil do vilic« ter vodenih doživetij in zelenih prireditev $\mathrm{z}$ lokalno dodano vrednostjo. To pa je pomembno orodje $\mathrm{v}$ rokah destinacijskega managementa in njegovega marketinga, kar lahko odločilno vpliva na izbor destinacije za počitnikovanje in njeno prepoznavnost $\mathrm{v}$ prihodnje. 
V drugem poglavju se Barbara Pavlakovič dotakne pomena prireditev v turizmu. Izpostavlja, da so dogodki eden od glavnih motivatorjev in generatorjev turističnih potovanj ter obiskov, torej so sestavni deli ponudbe določene destinacije, ki jih je seveda treba načrtovati in upravljati. Po mnenju številnih raziskovalcev so dogodki eden od najhitreje rastočih segmentov v turizmu, ki zajemajo vseobsegajočo paleto, od svetovnih pa do lokalnih razsežnosti. Pri tem je vsekakor pomembno izpostaviti tudi in predvsem manjše prireditve, ki so značilne za neko destinacijo (kot je primer tudi za destinacijo Podčetrtek, Bistrica ob Sotli in Kozje) in tako postanejo prepoznavni element v trženju turistične destinacije. Dogodki in prireditve pa niso samo turistična privlačnost, ampak imajo tudi vlogo povezovalca lokalnih skupnosti, z njihovo pomočjo oživljamo okolje destinacije, razvijamo kulturo ali gradimo lokalno identiteto, kar je vsekakor slučaj v primeru obravnavane destinacije. Seveda je pandemija COVID-19 presekala tudi ta segment turistične ponudbe, vendar in kot že izpostavljeno je pričakovati, da se bodo zadeve $\mathrm{v}$ prihodnje ponovno vrnile $\mathrm{v}$ neko »novo normalnost«, ki bo za organizatorje in obiskovalce optimalna glede na dane razmere tistega trenutka. Avtorica zaključi oziroma izpostavi tudi, da je pri organizaciji dogodkov pomembno skrbeti za naravo in okolje. Vse več je okoljsko ozaveščenih organizatorjev prireditev, ki si za cilj postavljajo ti. "zero waste« strategijo, kar pomeni, da odpadke pazljivo načrtujejo že od začetka načrtovanja prireditve, oziroma da uporabijo samo materiale, ki jih je možno ponovno uporabiti, reciklirati ali kompostirati.

V tretjem poglavju Mojca Bračun iz Turizma Podčetrtek, Bistrica ob Sotli in Kozje GIZ, predstavi destinacijo. Turistična destinacija, ki se nahaja na področju Obsotelja in Kozjanskega, vključuje tri občine: Podčetrtek, Bistrica ob Sotli in Kozje in se trži pod destinacijsko znamko Podčetrtek. Destinacija s svojimi $181,4 \mathrm{~km} 2$ tako predstavlja manjše regionalno območje, ki pa kljub svoji majhnosti s strateškim pristopom oblikuje svojo enovitost. Stopnja razvoja turizma je zelo visoka. Pestra ponudba temelji predvsem na naravnih danostih - tu prevladujeta termalna voda ter neokrnjena narava. Destinacija je bogata tudi na področju kulturnih virov in $s$ turistično infrastrukturo, ki je visokokakovostna. Čeprav majhna, se destinacija v turističnem smislu uvršča med uspešnejše in pomembnejše turistične regije. Glavnino turističnega prometa ustvari občina Podčetrtek s Termami Olimia, pomemben delež pa tudi občina Kozje s Kozjanskim regijskim parkom. Prireditve v tej ponudbi vsekakor predstavljalo pomembno dodano vrednost. 
V četrtem poglavju Valerija Slemenšek predstavi javni zavod Kozjanski park in festival Praznik Kozanskega jabolka. Kozjanski park je eno najstarejših in največjih zavarovanih območij v Sloveniji. Večji del Kozjanskega in Obsotelja je Republika Slovenija na osnovi kompromisa kulturnega izročila in naravovarstvenih vrednot leta 1981 razglasila za varovano območje - Spominski park Trebče. Park in strokovnjaki zaposleni $\mathrm{v}$ njem si prizadevajo za naravi prijazen razvoj, razvoj sonaravnega kmetovanja in nenazadnje trajnostni in odgovorni razvoj turizma znotraj območja parka. Avtorica poglavja izpostavi številne projekte in aktivnosti, ki potrjujejo to usmeritev. Posebej izpostavi prireditev Praznik kozjanskega jabolka, ki se je začela z namenom ohranjanje travniških sadovnjakov - tu namreč živijo nekatere vrste ogroženih ptic, kot so vijeglavka, zelena žolna, pivka, veliki skovik, pogorelček, čuk in rjavi srakoper; ravno zaradi njih so travniški sadovnjaki vključeni v območje Natura 2000 po »Ptičji direktivi«. Sama prireditev je bila torej začeta s ciljem, da se širši javnosti predstaviti nujnost ohranjanja tega habitata. Prireditev je iz skromnih začetkov prerasla $\mathrm{v}$ eno največjih in najodmevnejših tovrstnih prireditev v Sloveniji pa tudi širše, saj se je je v zadnjih letih udeležilo okoli 20.000 obiskovalcev. Bistvo prireditve Praznik kozjanskega jabolka je promocija in trženje produktov iz zavarovanega območja, ki se pridelujejo in predelujejo na ekološki in zdravju čimbolj prijazen način.

V petem poglavju je ekipa študentov 3. letnika univerzitetnega programa Turizem Fakultete za turizem Univerze $\mathrm{v}$ Mariboru ter študenta Erasmus+ programa pripravila SWOT analizo destinacije Podčetrtek, Bistrica ob Sotli in Kozje. Skupine so oblikovale vizijo destinacije, kulturnega turizma in prireditve Praznika kozjanskega jabolka. Sledijo cilji in akcijski načrti z ukrepi na področju kulturnega turizma. Pri tem izpostavljajo trajnostni razvoj turizma kot paradigmo razvoja za vsakogar v destinaciji. S trajnostnim turizmom imajo v mislih razvoj in vzdrževanje destinacije na tak način, da bo dolgoročno uspešno poslovala in pri tem ne bo ogrozila naravnega in družbenega okolja. Turizem za vsakogar pa naj bi vključeval vse starostne in interesne skupine turistov, ne glede na njihove oviranosti ali želje. Študenti oziroma delovne skupine so pripravile tudi akcijski načrt za uresničitve strateških ciljev. Ti ukrepi so zelo dobro razdelani in naslavljajo razvoj posameznih segmentov destinacijskega managementa, od izdelave vodnika, promocijskih vsebin, integralnih turističnih produktov, namenjenih za različne starostne skupine itd. Nabor je celovit in vseobsežen ter naslavlja vse stebre trajnostnega razvoja na destinaciji. 
$\mathrm{V}$ naslednjem poglavju šest so študenti oblikovali tudi splošne smernice za trajnostno poslovanje prireditev na destinaciji Podčetrtek, Bistrica ob Sotli in Kozje. Ugotavljajo, da so dogodki na destinaciji izjemnega pomena za širitev turistične ponudbe destinacije. Destinacija lahko ponudi različne oblike prireditev, pri tem pa bo morala v prihodnosti vsekakor razmisliti o načrtovanju in organizaciji dogodkov, ki so v skladu s trajnostnim razvojem. Študenti ugotavljajo, da obstaja več smernic, ki se jih mora držati organizator prireditve, če želi vzpostaviti dogodek, ki je okolju prijazen. Pri vseh teh dogodkih je zelo pomembno, da so upravljavci destinacije pozorni na nekaj postavk, ki so izjemno pomembne pri organizaciji trajnostnega dogodka. To so zagotovo lokacija in infrastruktura, naravno okolje, mobilnost, energija, odpadki, hrana in pijača, voda, družbena odgovornost ter oglaševanje ali promocija dogodkov.

V zadnjem sedmem poglavju pa so izpostavljene konkretne smernice, ki jih študenti predlagajo za organizacijo prireditve Praznik Kozjanskega jabolka 2021 (oziroma za prihodnja leta), da bi le-ta postala okoljsko bolj trajnostna. Ta paleta vključuje področja, kot so: ozaveščanje o trajnostnem razvoju, ponudbo novih dogodkov in vsebin, omejitve števila obiskovalcev in uvedba trajnostnih vstopnic na prireditvah, fokus na lokalni ponudbi in tradiciji, organizacijo logistike z združevanjem dostavnih vozil, vzpostavitev organizacije javnega prevoza na prireditev iz okoliških mest in manjših krajev, zmanjševanje vpliva na okolje s strani svetlobnega onesnaževanja in zmanjševanje hrupa, uporabo trajnostnih in biorazgradljivih materialov, uporabo ekoloških čistil, ureditve javnih toaletnih prostorov, ki varčujejo z vodo, pripravo »za vse dostopne prireditve (cilj je omogočiti dostop vsem, tudi tistim s posebnimi potrebami), zmanjševanje oziroma nadomeščanje tiskanih materialov, družbeno odgovorno ravnanje in delovanje lokalne skupnosti, prilagajanje termina izvedbe prireditve ter usmeritve za izvedbo v času epidemije. Skratka celovito in vseobsežno ter praktično uporabno gradivo.

V zaključku urednica Barbara Pavlakovič še enkrat poudari pomen prireditev kot posebne vrste turističnih znamenitosti in pomemben del turistične ponudbe destinacije. Izpostavi njihov potencial za trajnostno naravnanost in $\mathrm{s}$ tem spoštovanje odgovornega pristopa k turizmu. Še posebej pomembno se ji zdi osredotočenje na podeželske destinacije in možnosti, ki jih lahko zasledujemo na takih destinacijah. Kot zelo pomembne so poudarjene gastronomske prireditve, ki lahko uporabijo model znamčenja ponudbe s kolektivno blagovno znamko (KBZ) po modelu »Izvorno slovensko«. Praznik kozjanskega jabolka zagotovo že zdaj 
upošteva marsikatero od teh smernic, a pri tem je potrebno paziti, da se tako ravnanje ohrani tudi v prihodnosti. Po drugi strani pa je lahko Praznik kozjanskega jabolka zgled ostalim prireditvam tako na destinaciji Podčetrtek, Bistrica ob Sotli in Kozje kot drugje. Avtorica ugotavlja, da so prireditve lahko trajnostne le, če sledijo osnovnim usmeritvam trajnostnega delovanja.

Monografija z naslovom Priporočila za zelene prireditve: primer prireditve Praznik kozjanskega jabolka je zgleden primer, kako je potrebno preplesti raziskovalna in teoretična izhodišča ter jih interpretirati v praktične umeritve za turistične akterje $\mathrm{v}$ praksi. V vsakem resnejšem učbeniku metodologije družbenih raziskav bralce opozarjajo, da je treba pri oblikovanju raziskav jasno in natančno določiti namen raziskovanja, pri čemer je metodologija omejena le na dva osnovna namena: 1. teoretični namen, ki je poglabljanje ali širjenje teoretičnega znanja s področja, ki je izbrano za predmet raziskovanja, in 2. praktični namen, ki je namenjen reševanju določenega problema $\mathrm{v}$ praksi s pomočjo znanstvenoraziskovalnih postopkov. Ekipa Fakultete za turizem z mentoricama in urednicama doc. dr. Tanjo Lešnik Štuhec in asistentko Barbaro Pavlakovič je s to monografijo prav gotovo dosegla oba cilja. S poglabljanjem znanja in raziskovanja znanstvene zakladnice $\mathrm{s}$ to monografijo širijo obzorja deležnikov pri razvoju turizma na destinaciji Podčetrtek, Bistrica ob Sotli in Kozje na številnih področjih trajnostnega razvoja, upravljanja destinacije, s poudarkom na upravljanju trajnostnih prireditev $\mathrm{v}$ destinaciji.

Zato lahko to delo uvrstimo med znanstvene monografije, ker je njegov namen prenos znanstvenih dosežkov, metod in tehnik znanstvenega dela za reševanje praktičnih problemov. Čestitke urednicama in vsem sodelavcem, ki so sodelovali pri pripravi monografije z upanjem, da bodo deležniki na destinaciji Podčetrtek, Bistrica ob Sotli in Kozje, ki jim je ta monografija tudi najbolj namenjena, dobili strokovno in poglobljeno študijsko gradivo, uporabno in navdihujoče za njihovo trajnostno in odgovorno delovanje ter upravljanje njihove destinacije v prihodnjih letih.

Trebnje, 28. 6. 2021 


\section{Recenzija monografije}

MOJCA POLAK, MAG. MARK. IN PROD.

Gastronomija predstavlja pomembno turistično privlačnost zelenih destinacij. Njena povezava $z$ naravo, biotsko pestrostjo ter unikatnim kulinaričnim znanjem znotraj destinacije namreč omogoča preplet številnih oblik turistične ponudbe, ki se lahko z inovativnimi produkti približajo vsem segmentom gostov. Gastronomske prireditve lahko učinkovito povezujejo številne kulinarične privlačnosti destinacije v dogodke, ki promocijsko in vsebinsko podprejo posamezne gastronomske značilnosti. Zato je potrebno veliko pozornosti nameniti trajnostnim pristopom $\mathrm{k}$ prireditvam in pri tem upoštevati ustrezne smernice.

S tem namenom so študenti Fakultete za turizem Univerze v Mariboru skupaj z mentoricama kot študijo primera izbrali prireditev Praznik kozjanskega jabolka na destinaciji Podčetrtek, Bistrica ob Sotli in Kozje. Sam festival se namreč loteva promocije specifičnega in premalo valoriziranega sadja - jabolk, ki uspevajo na travnikih znotraj varovanega območja - Kozjanskega regijskega parka. Na osnovi raziskave obstoječega gradiva o destinaciji in festivalu so študenti pripravili obsežno SWOT analizo destinacije, v kateri so kot priložnosti za razvoj izpostavili tudi razmah butičnega turizma in razvoj novih inovativnih produktov, ki imajo potencial za personalizacijo. Med prednostmi zaznavajo pomen čistega okolja in narave ter 
posledično odlične pogoje za kmetijstvo in dodatno obogatitev že obstoječe raznovrstne gastronomske ponudbe. Ugotovitve raziskave izpostavljajo intenzivnejšo usmeritev v celovito trajnostno upravljanje destinacije in načrtovanje, izvajanje, spremljanje in evalviranje prireditve, kar vzpostavlja pomembno turistično dinamiko znotraj nje.

Študenti tako v nadaljevanju monografije predstavijo svoje videnje vizije trajnostne destinacije do leta 2030, ki bo ponujala sonaravni turizem za vse skupine gostov znotraj prepleta številnih zeleno naravnanih produktov. Pri tem skozi konkretne ukrepe osvetlijo tudi pomen gastronomskega turizma, ki bi se znotraj destinacije ves čas navezoval na zelene naravne vire ter biotske danosti. Prav tako pa bi gastronomski turizem ves čas povezoval ključne gastronomske značilnosti destinacije; to je kulturo vina, kozjansko jabolko, kulinarično dediščino ter Čokoladnico Olimje.

Pri ukrepih, ki so povezani s trajnostno produkcijo raznolikih prireditev, študenti poudarijo pomen lokacije, mobilnosti, rabe energije kot tudi manipulacije odpadkov. Znotraj ukrepov posebno pozornost namenijo segmentu hrane in vode. S poudarkom na vključevanju ekoloških živil, ki zagovarjajo filozofijo od vil do vilic, ter uporabo ekološko razgradljive embalaže se temu približajo tudi z idejo, da se presežki hrane namenijo socialno ogroženim skupinam.

V priporočilih za prireditev Praznik kozjanskega jabolka so študenti oblikovali številne smernice, ki posegajo na področje vsebinskih in izvedbenih aktivnosti. Pri tem so predstavili mnoge inovativne pristope, ki so s trajnostnega in družbeno odgovornega vidika osvetlili nove razvojne priložnosti prireditve. Še posebej priporočajo, da se v prihodnje ponudba hrane na omenjeni prireditvi čim bolj usmeri $\mathrm{v}$ jedi, ki temeljijo na rastlinskih živilih ekološke pridelave s kratkimi dobavnimi potmi. S tem bo prireditev Praznik kozjanskega jabolka ostala pomemben generator trajnostnega turizma na destinaciji, hkrati pa odločilno vplivala na odnos domačinov in turistov do dediščine destinacije Podčetrtek, Bistrica ob Sotli in Kozje.

Monografija z naslovom Priporočila za zelene prireditve: primer prireditve Praznik kozjanskega jabolka odlično prepleta teoretična in raziskovalna izhodišča ter jih prenaša $\mathrm{v}$ trajnostne smernice za praktično rabo deležnikov na destinaciji. 
Trdimo lahko, da je skupina študentov Fakultete za turizem z mentoricama in urednicama doc. dr. Tanjo Lešnik Štuhec in asistentko Barbaro Pavlakovič zgledno poglobljena teoretična znanja skozi raziskovalno metodologijo prenesla $\mathrm{v}$ prakso in $\mathrm{s}$ tem prispevala $\mathrm{k}$ nadgradnji trajnostnih prireditev ter turizma na destinaciji Podčetrtek, Bistrica ob Sotli in Kozje.

Monografija na osnovi metod in tehnik znanstvenega dela rešuje praktične probleme in pomembno sooblikuje prihodnost destinacije Podčetrtek, Bistrica ob Sotli in Kozje. Čestitke veljajo vsem vpletenim, tako študentom kot predstavnikom destinacije in mentoricama, ki so sodelovali pri pripravi monografije. Vsi skupaj se lahko veselimo nadgradnje prireditve in trajnostne usmeritve turizma na destinaciji.

Maribor, 5. 7. 2021 


\title{
PRIPOROČILA ZA ZELENE
}

\section{PRIREDITVE: PRIMER PRIREDITVE PRAZNIK KOZJANSKEGA JABOLKA}

\author{
BARBARA PAVLAKOVIČ IN TANJA LEŠNIK ŠTUHEC (UR.) \\ Univerza v Mariboru, Fakulteta za turizem, Brežice, Slovenija. \\ E-mail: barbara.pavlakovic@um.si, tanja.lesnik@um.si
}

Povzetek Prireditve oziroma dogodki so eden ključnih privlačnih elementov turistične ponudbe. Poznamo več vrst dogodkov, kot so kulturni, športni in izobraževalni. Pomembni elementi prireditev so zagotovo njihova vsebina, prav tako pa tudi gastronomska ponudba. Kolektivne blagovne znamke so pomembno orodje razvoja podeželja in $\mathrm{v}$ verige povezanih ponudnikov, ki zagotavljajo celovito visokokakovostno gastronomsko in $z$ njo povezano ponudbo strategije »od vil do vilic« ter vodenih doživetij in zelenih prireditev z lokalno dodano vrednostjo. Pri organizaciji je treba zagotoviti kar najboljšo kakovost izvedbe ter poskrbeti za varnost in trajnostno naravnanost prireditve, o čemer govori ta monografija. Prav smernice za trajnostne zelene prireditve so vodilo prihodnjega razvoja dogodkov na destinaciji Podčetrtek, Bistrica ob Sotli in Kozje, kjer so v sodelovanju s Fakulteto za turizem Univerze v Mariboru pristopili k skupnemu projektu trajnostnih turističnih rešitev za prihodnost. Zelene prireditve smo preučevali na primeru Praznika kozjanskega jabolka.

Ključne besede: turizem, podeželski turizem, trajnostni razvoj, zelene prireditve, dogodki, Praznik kozjanskega jabolka 


\title{
The Sustainable DeVELOPMENT PROGRAM OF GORSKI KOTAR
}

\author{
BARBARA PAVLAKOVIČ \& TANJA LEŠNIK ŠTUHEC (EDS.) \\ University of Maribor, Faculty of Tourism, Brežice, Slovenia \\ E-mail: barbara.pavlakovic@um.si, tanja.lesnik@um.si
}

\begin{abstract}
One of the key attractive elements of the tourist offer are events. We know several types of events, such as cultural, sports, educational. Essential elements of events are certainly their content, as well as the gastronomic offer. Collective brands are an important tool for rural development and chain-linked providers, providing comprehensive, high-quality gastronomic and related offerings from pitchfork to forks and guided experiences and green events with local added value. The organization must ensure the best possible quality of performance and ensure the safety and sustainable orientation of the event, as discussed in this monograph. The guidelines for a sustainable green event might guide the future development of events in Podčetrtek, Bistrica ob Sotli and Kozje, where they joined a sustainable future tourism solutions project in cooperation with the Faculty of Tourism of the University of Maribor. We studied green events on the example of the Kozjansko Apple Festival.
\end{abstract}

Keywords: tourism, rural tourism, sustainable development, green events, Kozjansko Apple Festival 


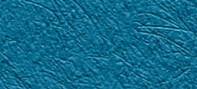

…ㄴ. 
im:

ane

Univerza y Mariboru

Fakulteta za turizem 